Key Words: MST

Actinide

Strontium

Retention: Permanent

\title{
Results of Supplemental MST Studies
}

\author{
T. B. Peters \\ D. T. Hobbs \\ S. D. Fink
}

July 24, 2006

Washington Savannah River Company

Savannah River Site

Aiken, SC 29808

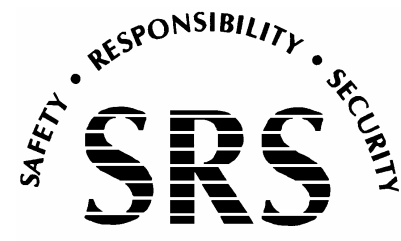


WSRC-STI-2006-00012, REV. 0

\title{
DISCLAIMER
}

This document was prepared in conjunction with work accomplished under Contract No. DE-AC09-96SR18500 with the U. S. Department of Energy.

This report was prepared as an account of work sponsored by an agency of the United States Government. Neither the United States Government nor any agency thereof, nor any of their employees, nor any of their contractors, subcontractors or their employees, makes any warranty, express or implied, or assumes any legal liability or responsibility for the accuracy, completeness, or any third party's use or the results of such use of any information, apparatus, product, or process disclosed, or represents that its use would not infringe privately owned rights. Reference herein to any specific commercial product, process, or service by trade name, trademark, manufacturer, or otherwise, does not necessarily constitute or imply its endorsement, recommendation, or favoring by the United States Government or any agency thereof or its contractors or subcontractors. The views and opinions of authors expressed herein do not necessarily state or reflect those of the United States Government or any agency thereof.

\section{Printed in the United States of America}

\author{
Prepared For \\ U.S. Department of Energy
}




\section{REVIEWS AND APPROVALS}

\section{AUTHORS}

\begin{tabular}{lr} 
& $8-1-2006$ \\
\hline T. B. Peters, co-author & Date \\
D. T. Hobbs, co-author & $8 / 7 / 06$ \\
\hline S. D. Fink, Manager, Process Chemistry and Science Group & Date \\
& $8-2-2006$ \\
\hline J.. . Griffin, Manager, Chemical Science and Technology Section & $8 / 3 / 06$ \\
\hline
\end{tabular}

DESIGN CHECK (per Manual E7, Procedure 2.60)

$8-1-2006$

C. J Martino, SRNL, Chemical Science and Technology Section Date

\section{CUSTOMERS}

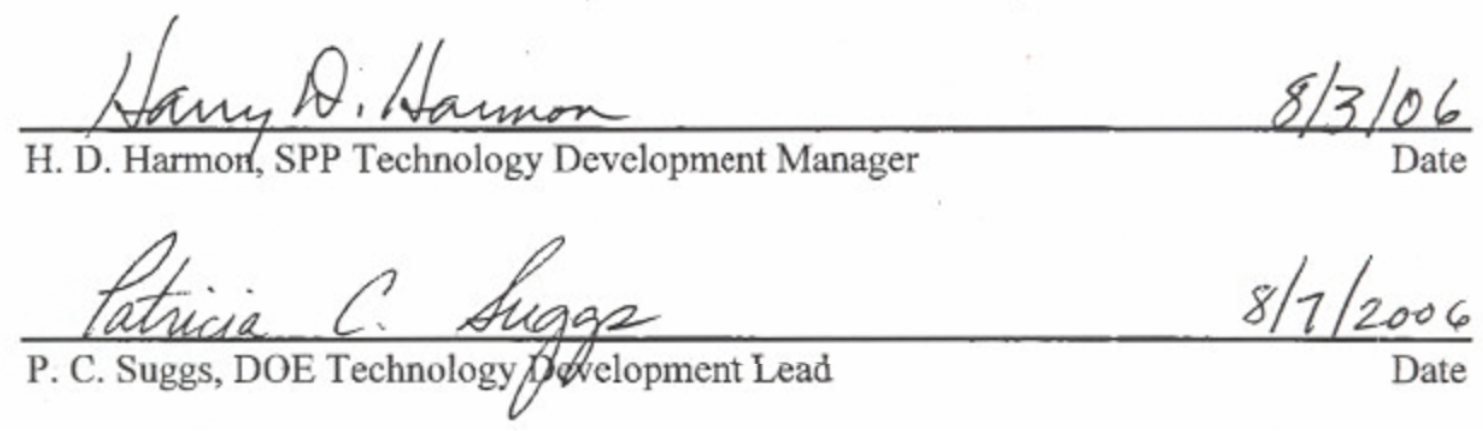




\section{LIST OF ACRONYMS}

$\begin{array}{ll}\text { ADS } & \text { Analytical Development Section } \\ \text { CSSX } & \text { Caustic-Side Solvent Extraction } \\ \text { DDI } & \text { distilled deionized water } \\ \text { DF } & \text { decontamination factor } \\ \text { DOE } & \text { Department of Energy } \\ \text { ICPES } & \text { Inductively Coupled Plasma - Emissions } \\ & \text { Spectroscopy } \\ \text { ICPMS } & \text { Inductively Coupled Plasma - Mass Spectroscopy } \\ \text { MST } & \text { Monosodium Titanate } \\ \text { PuTTa } & \text { Plutonium Thenoyl Trifluoroacetone } \\ \text { SRNL } & \text { Savannah River National Laboratory }\end{array}$




\subsection{EXECUTIVE SUMMARY}

The current design of the Salt Waste Processing Facility (SWPF) includes an auxiliary facility, the Actinide Finishing Facility, which provides a second contact of monosodium titanate (MST) to remove soluble actinides and strontium from waste if needed. This treatment will occur after cesium removal by Caustic-Side Solvent Extraction (CSSX). Although the process changes and safety basis implications have not yet been analyzed, provisions also exist to recover the MST from this operation and return to the initial actinide removal step in the SWPF for an additional (third) contact with fresh waste. A U.S. Department of Energy (DOE) request identified the need to study the following issues involving this application of MST.

- Determine the effect of organics from the solvent extraction (CSSX) process on radionuclide sorption by MST.

- Determine the efficiency of re-using MST for multiple contacts.

- Examine fissile loading on MST under conditions using a waste containing significantly elevated concentrations of plutonium, uranium, neptunium, and strontium.

This report describes the results of three experimental studies conducted to address these needs.

- Addition of high concentrations of entrained CSSX solvent had no noticeable effect, over a two week period, on the sorption of the actinides and strontium by MST in a direct comparison experiment.

- Test results show that MST still retains appreciable capacity after being used once. For instance, reused MST - in the presence of entrained solvent continued to sorb actinides and strontium.

- A single batch of MST was used to sequentially contact five volumes of a simulant solution containing elevated concentrations of the radionuclides of interest. After the five contacts, we measured the following solution actinide loadings on the MST:

plutonium: $0.884 \pm 0.00539 \mathrm{wt} \%$ or $(1.02 \pm 0.0112) \mathrm{E}+04 \mu \mathrm{g} / \mathrm{g} \mathrm{MST}$, uranium: $12.1 \pm 0.786 \mathrm{wt} \%$ or $(1.40 \pm 0.104) \mathrm{E}+05 \mu \mathrm{g} / \mathrm{g}$ MST, and neptunium: $0.426 \pm 0.00406 \mathrm{wt} \%$ or $(4.92 \pm 0.0923) \mathrm{E}+03 \mu \mathrm{g} / \mathrm{g} \mathrm{MST}$.

- Over the duration of an experiment with the sequential strikes, the ability of MST to sorb actinides improved with additional strikes. This trend is counter-intuitive, but is confirmed by replicate experiments for plutonium, uranium, and neptunium. Conversely, over the duration of the experiment, the ability of MST to sorb strontium decreased the more it was used. This trend is confirmed by replicate experiment. 


\subsection{INTRODUCTION}

Single contacts of waste with MST may not remove sufficient radionuclides from waste solutions to meet the processing goals of the SWPF. Mitigating actions may include, for example, multiple sequential contacts with MST. The current design of the SWPF includes an auxiliary facility, the Actinide Finishing Facility ${ }^{1}$, which provides a second contact of MST to remove residual soluble actinides and strontium from waste. This treatment will occur after cesium removal by CSSX. Provisions also exist to recover the MST from the Actinide Finishing Facility operation and return to the initial actinide removal step in the SWPF for an additional contact with fresh waste. Conducting an MST treatment step after CSSX raises a previously unexamined technical concern by adding the complexity of entrained organic contacting the MST sorbent and potentially degrading performance. Prior experiments did not examine the impact of these organics on MST performance. This approach adds uncertainty about the sorption efficiency during a second contact. Similarly, the repeated contacting will increase the potential for high fissile loading. The maximum loading of fissile species - particularly uranium - is not known and remains a technical risk. ${ }^{2}$

A recent U.S. Department of Energy (DOE) request highlighted these needs for studies involving this application of MST. ${ }^{3}$

- The effect of organics from the solvent extraction (CSSX) process on radionuclide sorption by MST

- The effect of re-using MST for multiple contacts

- The maximum actinide (in particular, uranium and plutonium) loading for MST

The following assumptions are implicit in this study.

- The simulated waste adequately mirrors behavior over a range of actual waste compositions. The bulk inorganic composition mimics that used in past studies. Historical data suggests reasonable ability to predict actual waste performance based on these studies. ${ }^{4}$

- The omission of sludge solids otherwise normally present in actual wastes (during the initial SWPF MST strike and MST reuse) will not cause the simulant waste to deviate substantially from the behavior of actual waste. Past experiments do indicate that sludge solids add complexity to the radionuclide behavior - and especially that of strontium - but with minor relative impact. ${ }^{5}$

- Analysis of previous data has not been able to discern a clear competitive effect between strontium and actinides. Thus, the high cold strontium values chosen for section 3.2 were chosen not to test for a competitive effect, but to more closely simulate waste incoming to the actual facility. 
- The current testing uses solutions with simultaneously higher concentrations of radionuclides than any past study. Higher concentrations are known to shift the sorption behavior for some of the radionuclides. ${ }^{13}$ As a result, trends for those experiments may differ from pretest expectations.

\subsection{EXPERIMENTAL}

SRNL performed a series of three sets of experiments to address the technical needs. Each set occurred independently.

\subsection{Effect of CSSX Organic on MST Performance}

For these experiments, two parallel tests (one of which serves as a control) were performed, where each test used a single bottle of simulant. The tests used $450 \mathrm{~mL}$ of an already existing simulant with composition detailed in Table 1 . Only the actinide and strontium concentrations were confirmed before using this material. Due to the short halflife of ${ }^{85} \mathrm{Sr}$ (64 days) we added additional ${ }^{85} \mathrm{Sr}$ to the existing simulant to reach an activity level of $50,000 \mathrm{dpm} / \mathrm{mL}$ prior to testing.

\section{Table 1. Salt Solution Composition Used in MST Organic Testing}

\begin{tabular}{|c|c|}
\hline Component & Target Concentration \\
\hline $\mathrm{NaNO}_{3}$ & $2.60 \mathrm{M}$ \\
\hline $\mathrm{NaOH}$ & $1.33 \mathrm{M}$ \\
\hline $\mathrm{Na}_{2} \mathrm{SO}_{4}$ & $0.521 \mathrm{M}$ \\
\hline $\mathrm{NaNO}_{2}$ & $0.134 \mathrm{M}$ \\
\hline total Na & $5.60 \mathrm{M}$ \\
\hline stable strontium & $<100 \mu \mathrm{g} / \mathrm{L}$ \\
\hline${ }^{85} \mathrm{Sr}$ & $50,000 \mathrm{dpm} / \mathrm{mL}(9.54 \mathrm{E}-04 \mu \mathrm{g} / \mathrm{L})$ \\
\hline${ }^{237} \mathrm{~Np}$ & $565 \mu \mathrm{g} / \mathrm{L}$ \\
\hline${ }^{238} \mathrm{U}$ & $10,000 \mu \mathrm{g} / \mathrm{L}$ \\
\hline${ }^{239 / 40} \mathrm{Pu}$ & $200 \mu \mathrm{g} / \mathrm{L}$ \\
\hline
\end{tabular}

For the first experiment technicians agitated $1.21 \mathrm{~g}$ of MST slurry (Optima batch \#00QAB-417, $0.18 \mathrm{~g}$ of MST solids) in $225 \mu \mathrm{L}$, or $500 \mathrm{ppmv}$ ) of CSSX solvent. ${ }^{\mathrm{r}}$ The solvent was from lot PVB 000894-87W and was the full (all components) solvent. The solvent and MST were added to a small glass vial. The total contents were then

\footnotetext{
${ }^{\Upsilon} 0.4 \mathrm{~g}$ of MST solids is used for each liter of simulant, or $0.18 \mathrm{~g}$ for each $450 \mathrm{~mL}$ of simulant. The most recent analysis of the MST slurry indicates an insoluble solids content of $14.8 \mathrm{wt} \%$. The density of this MST slurry is $1.12 \mathrm{~g} / \mathrm{mL}$. Therefore, for each $450 \mathrm{~mL}$ of simulant, we add $1.08 \mathrm{~mL}$ of MST slurry.
} 
intimately contacted using a pipette to draw and then expel the contents into the glass vial over a duration of 30 seconds. The resulting mixture appeared homogenous with no indications of gelling, setting or layer separation (a previous proof of concept test involving mixing these 2 materials indicated partial phase separation after 24 hours). The thorough mixing was selected to conservatively bound the conditions in the actual facility where MST added to the tank would fall through a thin organic layer on top of the tank contents. After thorough agitation, personnel added this mixture to $450 \mathrm{~mL}$ of the simulant solution.

For the second (control) experiment, technicians added $1.22 \mathrm{~g}$ of MST slurry (Optima \#00-QAB- 417, $0.18 \mathrm{~g}$ of solids) to $450 \mathrm{~mL}$ of the simulant solution without any solvent. Personnel placed both bottles in a shaker oven for temperature control and continual agitation, maintaining temperatures at $28 \pm 3{ }^{\circ} \mathrm{C}$. The original intent was to maintain at $25 \pm 3{ }^{\circ} \mathrm{C}$, the equipment proved incapable of maintaining the setpoint temperature due to no cooling capacity. Previous work ${ }^{6}$ indicates that this small temperature difference should cause no measurable impact.

Six hours after adding MST to each of the solutions, technicians collected three filtrate samples from each of the two bottles by filtering a few milliliters of solution through a $0.1 \mu \mathrm{m}$ polyvinylidene difluoride (PVDF) syringe filter. At 24 and 168 hours after MST addition, personnel collected a single filtrate sample by filtering a few milliliters of solution through a $0.45 \mu \mathrm{m}$ nylon syringe filter.

Technicians diluted the filtrate samples with an equal volume of $5 \mathrm{M} \mathrm{HNO}_{3}$ and allowed to sit for at least 2 hours before sending to ADS for analysis. Personnel verified the absence of visible solids in the aliquots provided for analysis.

\subsection{Effect of MST Reuse}

This task involved two parallel experiments, as well as a single control experiment. A new simulant solution was prepared for this work. The simulant preparation of this work proved problematic. Our original intent was to create a simulant with the typical cold chemical concentrations, and high cold strontium and actinide concentrations (Table 2). The high cold strontium was added to more accurately simulate a typical tank waste. However, the solution proved unstable, and the soluble cold strontium and radioisotope concentrations were less than desired due to precipitation. 
Table 2. MST Reuse Simulant $\left(1^{\text {st }}\right.$ Attempt $)$

\begin{tabular}{|c|c|c|}
\hline Component & Target Concentration & Measured Result \\
\hline Nitrate & $2.60 \mathrm{M}$ & $2.71 \pm 0.271$ \\
\hline free hydroxide & $1.33 \mathrm{M}$ & $1.31 \pm 0.131$ \\
\hline Sulfate & $0.521 \mathrm{M}$ & $0.526 \pm 0.0526$ \\
\hline Nitrite & $0.134 \mathrm{M}$ & $0.142 \pm 0.0142$ \\
\hline (AA) total $\mathrm{Na}^{+}$ & $5.60 \mathrm{M}$ & $5.27 \pm 1.05$ \\
\hline (ICPES) total Na $^{+}$ & $5.60 \mathrm{M}$ & $4.91 \pm 0.491$ \\
\hline stable strontium & $11,000 \mu \mathrm{g} / \mathrm{L}$ & $7,360 \pm 1,470$ \\
\hline${ }^{85} \mathrm{Sr}$ & $50,000 \mathrm{dpm} / \mathrm{mL}$ & $47,300 \pm 771$ \\
& $(9.54 \mathrm{E}-04 \mu \mathrm{g} / \mathrm{L})$ & $(9.02 \mathrm{E}-04 \mu \mathrm{g} / \mathrm{L})$ \\
\hline${ }^{237} \mathrm{~Np}$ & $500 \mu \mathrm{g} / \mathrm{L}$ & $86.8 \pm 17.4$ \\
\hline${ }^{238} \mathrm{U}$ & $25,000 \mu \mathrm{g} / \mathrm{L}$ & $9,170 \pm 1,830$ \\
\hline${ }^{239 / 40} \mathrm{Pu}$ & $1200 \mu \mathrm{g} / \mathrm{L}$ & $19.5 \pm 0.975$ \\
\hline
\end{tabular}

A second attempt was made to create a simulant with the same target concentrations as the first attempt (Table 3).

Table 3. MST Reuse Simulant $\left(2^{\text {nd }}\right.$ Attempt $)$

\begin{tabular}{|c|c|c|}
\hline Component & Target Concentration & Measured Result \\
\hline Nitrate & $2.60 \mathrm{M}$ & $2.74 \pm 0.274$ \\
\hline free hydroxide & $1.33 \mathrm{M}$ & $1.19 \pm 0.119$ \\
\hline Sulfate & $0.521 \mathrm{M}$ & $0.564 \pm 0.0564$ \\
\hline Nitrite & $0.134 \mathrm{M}$ & $0.143 \pm 0.0143$ \\
\hline total Na & $5.60 \mathrm{M}$ & $5.20 \pm 0.520$ \\
\hline stable strontium & $11,000 \mu \mathrm{g} / \mathrm{L}$ & $9,010 \pm 1,800$ \\
\hline${ }^{85} \mathrm{Sr}$ & $50,000 \mathrm{dpm} / \mathrm{mL}$ & $30,700 \pm 699$ \\
& $(9.54 \mathrm{E}-04 \mu \mathrm{g} / \mathrm{L})$ & $(5.86 \mathrm{E}-04 \mu \mathrm{g} / \mathrm{L})$ \\
\hline${ }^{237} \mathrm{~Np}$ & $500 \mu \mathrm{g} / \mathrm{L}$ & $165 \pm 33.0$ \\
\hline${ }^{238} \mathrm{U}$ & $25,000 \mu \mathrm{g} / \mathrm{L}$ & $15,700 \pm 3,140$ \\
\hline${ }^{239 / 40} \mathrm{Pu}$ & $1,200 \mu \mathrm{g} / \mathrm{L}$ & $190 \pm 10.8$ \\
\hline
\end{tabular}

As with the first attempt, after the two week equilibrium period, it was obvious the cold strontium and actinide concentrations were less than desired. After these two attempts we hypothesize that solutions of this composition are not chemically stable enough to be used. With customer concurrence, we decided to take the solution from the second attempt (Table 4), filter the solids off and spike with ${ }^{238} \mathrm{Pu}$, as well as re-spiking with ${ }^{85} \mathrm{Sr}$ for the purposes of calculating decontamination factors. After spiking this solution was allowed to equilibrate for 2 weeks and analyzed over that time (see Appendix I for the 
equilibrium values). This time, the simulant was filtered to remove solids and declared to be adequate for our uses without further modification.

Table 4. Final MST Reuse Simulant $\left(3^{\text {rd }}\right.$ Attempt $)$

\begin{tabular}{|c|c|c|}
\hline Component & Target Concentration & Measured Result \\
\hline Nitrate & $2.60 \mathrm{M}$ & $2.99 \pm 0.299$ \\
\hline free hydroxide & $1.33 \mathrm{M}$ & $1.22 \pm 0.122$ \\
\hline Sulfate & $0.521 \mathrm{M}$ & $0.477 \pm 0.0477$ \\
\hline Nitrite & $0.134 \mathrm{M}$ & $0.140 \pm 0.0140$ \\
\hline total Na & $5.60 \mathrm{M}$ & $4.91 \pm 0.491$ \\
\hline stable strontium & $9,320 \mu \mathrm{g} / \mathrm{L}$ & $9,270 \pm 1,940$ \\
\hline${ }^{85} \mathrm{Sr}$ & $50,000 \mathrm{dpm} / \mathrm{mL}$ & $56,600 \pm 1,130$ \\
& $(9.54 \mathrm{E}-04 \mu \mathrm{g} / \mathrm{L})$ & $(1.08 \mathrm{E}-03 \mu \mathrm{g} / \mathrm{L})$ \\
\hline${ }^{237} \mathrm{~Np}$ & $165 \mu \mathrm{g} / \mathrm{L}$ & $121 \pm 24.2$ \\
\hline${ }^{238} \mathrm{U}$ & $15,700 \mu \mathrm{g} / \mathrm{L}$ & $13,800 \pm 2,760$ \\
\hline${ }^{238} \mathrm{Pu}$ & $50,000 \mathrm{dpm} / \mathrm{mL}$ & $56,700 \pm 2,880$ \\
& $(1.32 \mu \mathrm{g} / \mathrm{L})$ & $(1.50 \mu \mathrm{g} / \mathrm{L})$ \\
\hline
\end{tabular}

For each of the two parallel experiments, researchers used two 1-L Teflon ${ }^{\mathrm{TM}}$ bottles containing simulant. The reaction sequence follows (also see Figure 1).

1) Strike "B": Researchers weighed out and added $2.70 \mathrm{~g}$ of MST slurry (QAB 417, $0.4 \mathrm{~g}$ of solids) to the $1 \mathrm{~L}$ bottle (designated Bottle \#1 in Figure 1).

Technicians sampled the filtrate after 6 hours time, and completely filtered the MST within an hour of the filtrate sampling, giving an approximate contact time of 6.5 hours. (Although the intent was to filter and sample simultaneously, filtration required about 1 hour to complete). This first MST addition simulates the pre-CSSX MST treatment of the waste.

2) Strike "C": Researchers added 500 ppmv of CSSX solvent to the radionuclidedepleted simulant solution (i.e., the filtrate). The solvent was not explicitly mixed with MST beforehand. They contacted this depleted, organic-containing simulant with a fresh addition of MST and sampled after 6 hours time. This second MST addition simulates the post-CSSX MST treatment of the waste in the Alpha Finishing Facility.

3) Personnel recovered the MST used in second step using a $0.45 \mu \mathrm{m}$ nylon filter disk.

4) Strike "D": Researchers added this recovered MST to a fresh, 1L batch of simulant (designated as "Bottle \#2" in Figure 1). Personnel sampled the filtrate 
after 6 hours. This step simulated the reuse of a batch of MST from the Alpha Finishing Facility on a fresh batch of incoming waste (pre-CSSX) within the Alpha Strike Process.

5) The MST used in Step \#4 was recovered from solution by filtration after collecting the 6 hour sample. Personnel performed a sodium peroxide digestion on the MST and analyzed to determine the actinide and strontium loading.

6) Strike "E": Personnel contacted the filtrate obtained following Step \#2 with a fresh batch of MST and sampled after 6 hours. This test roughly approximates the third MST addition in the Alpha Finishing Facility of the SWPF process, differing in that the solvent addition occurred after the first addition whereas in actual plant operations the solvent contact would occur after the second MST treatment of the waste.

Figure 1. Experimental Pathway for Section 3.2.2

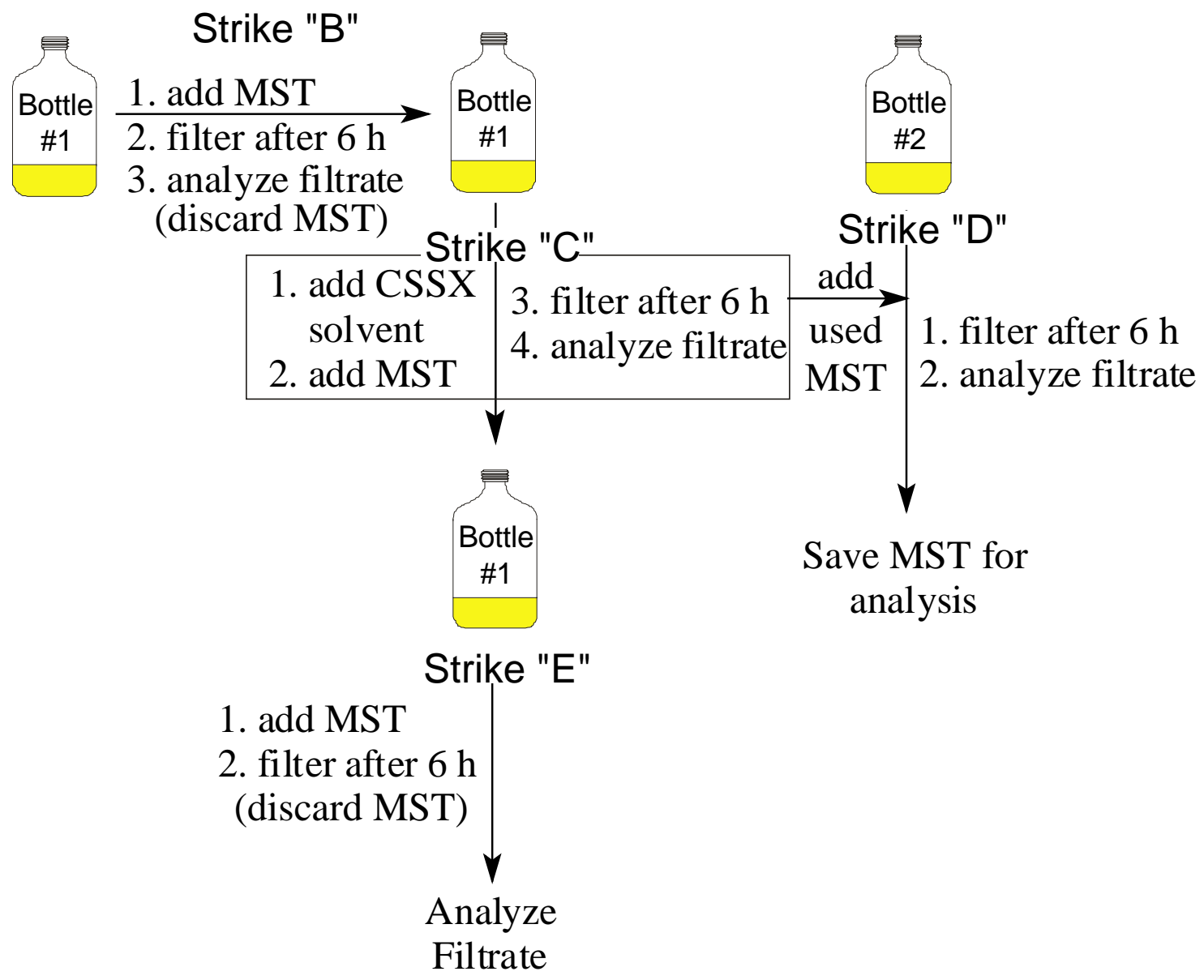


When recovering the MST by filtration, researchers used removable $0.45 \mu \mathrm{m}$ nylon membrane filters. When the MST was saved for further use or analysis, personnel placed the filter into a sealed bottle and added a few drops of DDI water to prevent the MST from drying.

Finally, personnel sampled a single control bottle at the same time as sampling either Bottle \#1 or Bottle \#2.

\subsection{Fissile Loading Tests}

The third set of experiments examined the effects of sequential 1-L simulant contacts on a single batch of MST. Sequential contacts provide increased amount of fissile material for sorption. These tests used a simulant with approximately the same inorganic (i.e., sodium, nitrate, nitrite, sulfate and free hydroxide) composition as Table 5 with the exception that personnel did not add stable strontium. Stable strontium was not added so as to minimize any potential sorption competition with the actinides although after reviewing historical data we have been unable to discern a competitive effect.

Table 5. Fissile Loading Simulant

\begin{tabular}{|c|c|c|}
\hline Component & Target Concentration & Measured Result \\
\hline Nitrate & $2.60 \mathrm{M}$ & $2.59 \pm 0.259$ \\
\hline free hydroxide & $1.33 \mathrm{M}$ & $1.34 \pm 0.134$ \\
\hline Sulfate & $0.521 \mathrm{M}$ & $0.508 \pm 0.0508$ \\
\hline Nitrite & $0.134 \mathrm{M}$ & $0.133 \pm 0.0133$ \\
\hline total Na & $5.60 \mathrm{M}$ & $5.13 \pm 0.513$ \\
\hline${ }^{+} \mathrm{Sr}$ & $50,000 \mathrm{dpm} / \mathrm{mL}$ & $29,500 \pm 590$ \\
& $(9.54 \mathrm{E}-04 \mu \mathrm{g} / \mathrm{L})$ & $(5.63 \mathrm{E}-04 \mu \mathrm{g} / \mathrm{L})$ \\
\hline${ }^{237} \mathrm{~Np}$ & $500 \mu \mathrm{g} / \mathrm{L}$ & $476 \pm 95.2$ \\
\hline${ }^{238} \mathrm{U}$ & $25,000 \mu \mathrm{g} / \mathrm{L}$ & $26,500 \pm 5,300$ \\
\hline${ }^{239 / 40} \mathrm{Pu}$ & $1,200 \mu \mathrm{g} / \mathrm{L}$ & $847 \pm 169$ \\
\hline
\end{tabular}

Appendix I lists the target and measured values for this simulant after equilibrium. Personnel contacted an aliquot of MST with sequential amounts of fresh simulant solutions, recovering the MST by filtration after each contact. The experiments occurred in duplicate. For the first five MST contacts, personnel sampled the filtrate 24 hours after the addition of the MST to the fresh simulant solution. After sampling at 24 hours, technicians recovered the MST by filtration and transferred the solids to a fresh bottle of 
simulant. After the 24 hour sample from the fifth strike, personnel recovered the MST by filtration for analysis.

In parallel, researchers performed a single strike on a bottle containing simulant (to serve as a control). Technicians sampled the filtrate 24 and 168 hours after the MST strike. Personnel recovered the MST by filtration after the 168 hour sample.

Another parallel experiment measured the stability of the radionuclides within a bottle containing simulant without MST addition (i.e., a blank). Personnel sampled this slurry after 24, 96 and 120 hours.

Technicians isolated the MST samples, digested using sulfuric or a combination of sulfuric and nitric acids, and analyzed for a radionuclide mass balance versus the filtrate. Temperature control and agitation was provided by shaker heater units controlling at $28 \pm 3{ }^{\circ} \mathrm{C}$.

When recovering the MST by filtration, researchers used removable $0.45 \mu$ m nylon membrane filters. When saving the MST for further use or analysis, personnel placed the filter into a sealed bottle and added a few drops of DDI water to prevent the MST from drying.

\subsection{EXPERIMENTAL RESULTS}

Personnel analyzed each filtrate sample for ${ }^{85} \mathrm{Sr},{ }^{238} \mathrm{U},{ }^{237} \mathrm{~Np}$, and ${ }^{239 / 40} \mathrm{Pu}$ content, either by ICPMS or Gamma Counting. Note that the ICPMS data has a fixed $20 \%$ uncertainty associated with each data point. This fixed uncertainty is due to the ability to determine actual uncertainty at each mass (80 to 248) in a reasonable amount of time. All analytical uncertainties are one sigma. In cases with replicates of the same measurement, we used standard deviation of the values from the mean to derive the uncertainty. Although not originally intended the Gamma Counting provides a reliable analysis of the ${ }^{233} \mathrm{~Pa}$ (protactinium) in solution. Personnel use the measured values to determine the decontamination factor (DF) at each sample collection time. In each of the tests, the Decontamination factor is calculated by dividing the initial species concentration by the species concentration in solution at the time of measurement (e.g., 6, 24, and 168 hours). Appendix II discusses calculation of uncertainty values for measured DFs.

\subsection{Effect of CSSX Organic on MST Performance}

\subsubsection{MST Sorption of Plutonium}

Personnel monitored ${ }^{239 / 40} \mathrm{Pu}$ in solution by two analytical methods: PuTTa (Table 6) and ICPMS (Table 7). Figure 2 provides a graphical representation of the data. The MST trend in sorption with time agrees with expectations based on past experiments. ${ }^{7,8}$ What 
differences we can see between the DF results are attributable to differences in the chemical composition of the solutions. The DF values increase over one week to about twice the initial value. The two analytical methods provide consistent values. In all cases, the DF values determined for both the organic-bearing and organic-free experiments fall within the range including each analytical method's uncertainties. This observation indicates that the presence of the organic does not influence the sorption over the limited duration of the experiments.

Table 6. ${ }^{239 / 40} \mathrm{Pu}$ Results With and Without CSSX Solvent as Determined by PuTTA

\begin{tabular}{|c|c|c|c|c|}
\hline \multirow{2}{*}{$\begin{array}{c}\text { Time } \\
\text { (hours) }\end{array}$} & \multicolumn{2}{|c|}{${ }^{239 / 40} \mathrm{Pu}$ DF Values } & \multicolumn{2}{c|}{ Solution ${ }^{239 / 40} \mathrm{Pu} \mu \mathrm{g} / \mathrm{L}$ Values } \\
\cline { 2 - 5 } & No Organic & Organic & No Organic & Organic \\
\hline $6^{*}$ & $5.34 \pm 0.756$ & $4.88 \pm 0.689$ & $27.9 \pm 2.46$ & $30.6 \pm 4.82$ \\
\hline 24 & $5.42 \pm 0.615$ & $6.13 \pm 0.711$ & $27.6 \pm 1.48$ & $24.4 \pm 1.44$ \\
\hline 168 & $11.7 \pm 1.31$ & $13.9 \pm 1.60$ & $12.8 \pm 0.647$ & $10.7 \pm 0.612$ \\
\hline
\end{tabular}

* The 6 hour samples are triplicates; other samples are single analyses.

Table 7. ${ }^{239}$ Pu Results With and Without CSSX Solvent as Determined by ICPMS

\begin{tabular}{|c|c|c|c|c|}
\hline \multirow{2}{*}{$\begin{array}{c}\text { Time } \\
\text { (hours) }\end{array}$} & \multicolumn{2}{|c|}{${ }^{239} \mathrm{Pu}$ DF Values } & \multicolumn{2}{c|}{ Solution ${ }^{239} \mathrm{Pu} \mu \mathrm{g} / \mathrm{L}$ Values } \\
\cline { 2 - 5 } & No Organic & Organic & No Organic & Organic \\
\hline $6^{*}$ & $6.42 \pm 1.82$ & $6.06 \pm 1.71$ & $27.4 \pm 5.48$ & $29.1 \pm 5.82$ \\
\hline 24 & $8.22 \pm 2.33$ & $8.22 \pm 2.33$ & $21.4 \pm 4.28$ & $21.4 \pm 4.28$ \\
\hline 168 & $15.8 \pm 4.47$ & $13.6 \pm 3.84$ & $11.1 \pm 2.22$ & $13.0 \pm 2.60$ \\
\hline
\end{tabular}

* The 6 hour samples are triplicates; other samples are single analyses. 
Figure 2. Plutonium Concentration Over Time With and Without CSSX Solvent

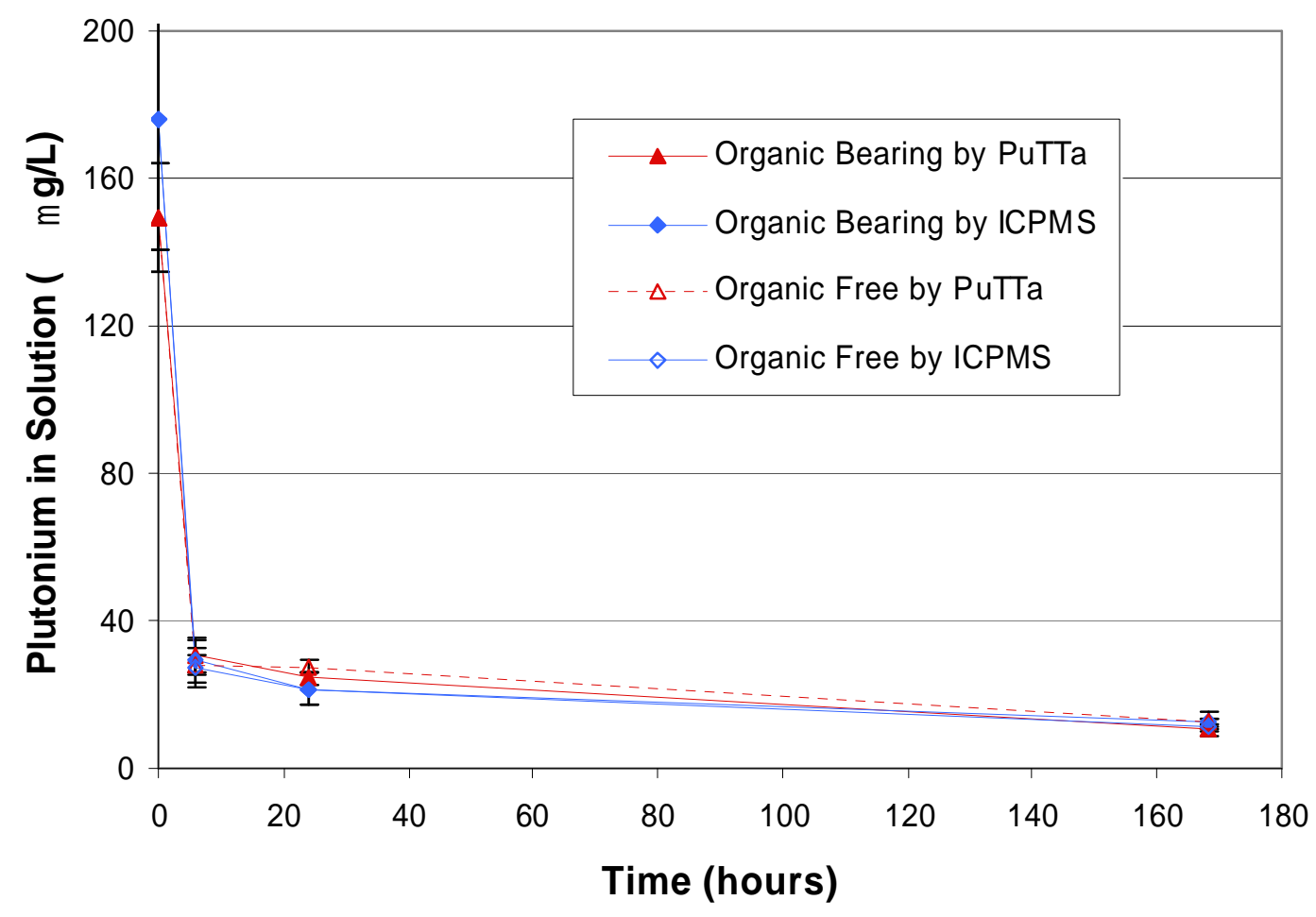

\subsubsection{MST Removal of Strontium}

Personnel added ${ }^{85} \mathrm{Sr}$ to the salt solution. Since this radionuclide rapidly decays with a half-life of $65.2^{9}$ days, we applied decay correction to all the values. Table 8 provides DF values as determined by the ${ }^{85} \mathrm{Sr}$ data. Figure 3 contains a graphical representation of the data.

Removal of strontium from solution is rapid but declines slightly over time. Some previous work ${ }^{10}$ has seen the same type of drop in DF over time, but this is an intermittent observation. At this time we are uncertain as to the cause of this decline.

Examination of the measurements for the organic-bearing and organic-free solutions shows no statistical difference between the two sets of values. We conclude that the presence of the $500 \mathrm{ppm}$ of CSSX solvent has no effect on MST removal of strontium within the duration (i.e., one week and less) of the experiments. 


\section{Table 8. ${ }^{85}$ Sr Results With and Without CSSX Solvent as Determined by Gamma} Counting

\begin{tabular}{|c|c|c|c|c|}
\hline \multirow{2}{*}{$\begin{array}{c}\text { Time } \\
\text { (hours) }\end{array}$} & \multicolumn{2}{|c|}{${ }^{85} \mathrm{Sr}$ DF Values } & \multicolumn{2}{c|}{ Solution ${ }^{85} \mathrm{Sr} \mu \mathrm{g} / \mathrm{L}$ Values } \\
\cline { 2 - 5 } & No Organic & Organic & No Organic & Organic \\
\hline $6^{*}$ & $249 \pm 14.0$ & $237 \pm 16.9$ & $(3.38 \pm 0.290) \mathrm{E}-06$ & $(3.56 \pm 0.249) \mathrm{E}-06$ \\
\hline 24 & $207 \pm 7.85$ & $197 \pm 6.70$ & $(4.06 \pm 0.139) \mathrm{E}-06$ & $(4.27 \pm 0.127) \mathrm{E}-06$ \\
\hline 168 & $167 \pm 5.45$ & $171 \pm 5.47$ & $(5.03 \pm 0.142) \mathrm{E}-06$ & $(4.93 \pm 0.136) \mathrm{E}-06$ \\
\hline
\end{tabular}

As we did not add cold strontium, the ${ }^{85} \mathrm{Sr} \mu \mathrm{g} / \mathrm{L}$ loading values do not include cold strontium mass.

Figure 3. ${ }^{85}$ Sr Concentration Over Time With and Without CSSX Solvent

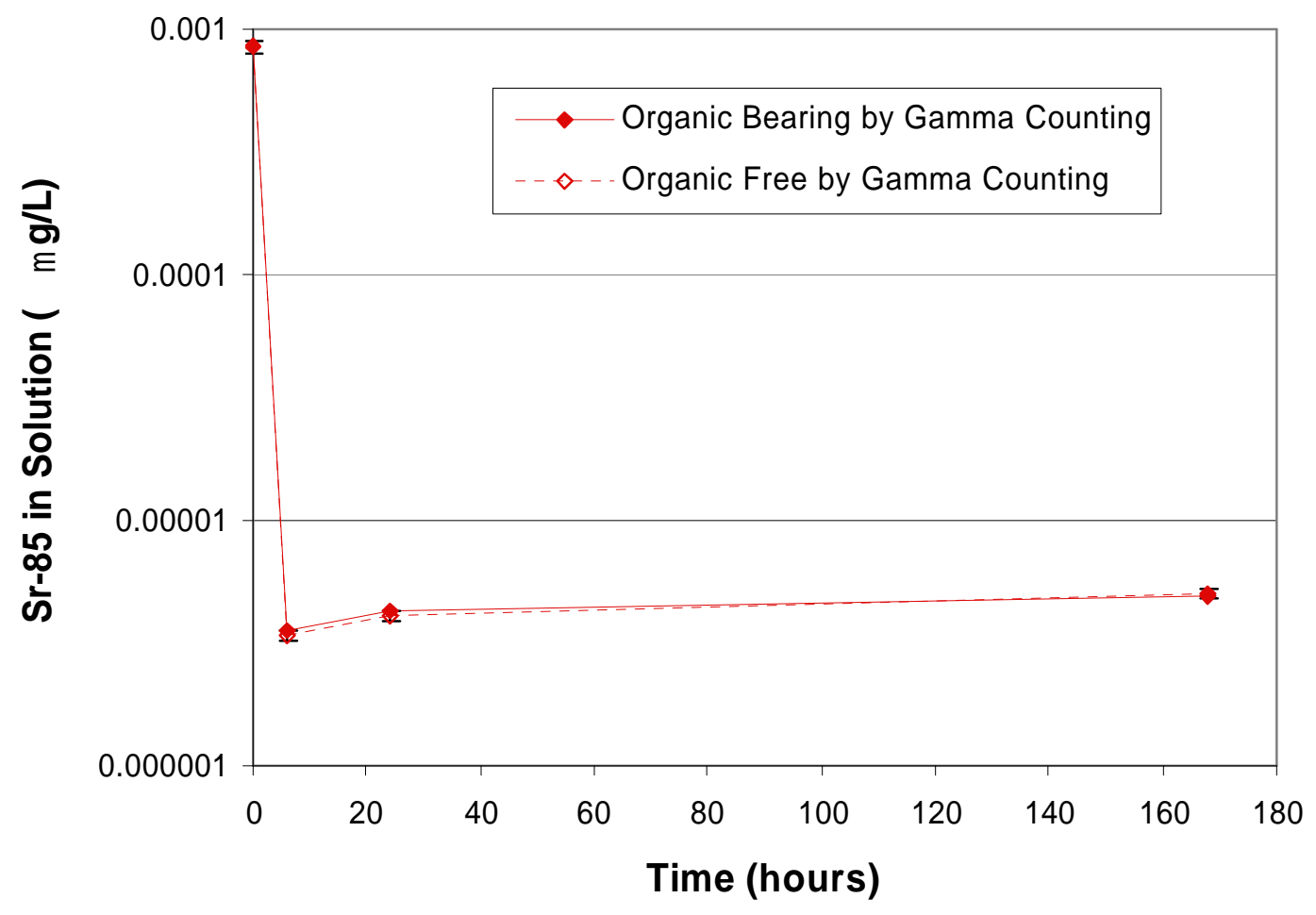


4.1.3 MST Sorption of Neptunium

Personnel monitored the ${ }^{237} \mathrm{~Np}$ in solution by Gamma Counting (Table 9) and ICPMS (Table 10). Figure 4 graphically depicts the data.

Table 9. ${ }^{237}$ Np DF With and Without CSSX Solvent as Determined by Gamma Counting

\begin{tabular}{|c|c|c|c|c|}
\hline \multirow{2}{*}{$\begin{array}{c}\text { Time } \\
\text { (hours) }\end{array}$} & \multicolumn{2}{|c|}{${ }^{237} \mathrm{~Np}$ DF Values } & \multicolumn{2}{c|}{ Solution $^{237} \mathrm{~Np} \mathrm{\mu g/L} \mathrm{Values}$} \\
\cline { 2 - 5 } & No Organic & Organic & No Organic & Organic \\
\hline $6^{*}$ & $1.46 \pm 0.186$ & $1.39 \pm 0.298$ & $393 \pm 11.9$ & $412 \pm 42.6$ \\
\hline 24 & $1.84 \pm 0.149$ & $1.70 \pm 0.124$ & $313 \pm 17.8$ & $337 \pm 14.6$ \\
\hline 168 & $2.87 \pm 0.291$ & $2.65 \pm 0.209$ & $201 \pm 16.7$ & $217 \pm 11.6$ \\
\hline
\end{tabular}

* The 6 hour samples are triplicates; other samples are single analyses

Table 10. ${ }^{237} \mathrm{~Np}$ DF With and Without CSSX Solvent as Determined by ICPMS

\begin{tabular}{|c|c|c|c|c|}
\hline \multirow{2}{*}{$\begin{array}{l}\text { Time } \\
\text { (hours) }\end{array}$} & \multicolumn{2}{|c|}{${ }^{237} \mathrm{~Np}$ DF Values } & \multicolumn{2}{|c|}{ Solution ${ }^{237} \mathrm{~Np} \mu \mathrm{g} / \mathrm{L}$ Values } \\
\hline & No Organic & Organic & No Organic & Organic \\
\hline $6^{*}$ & $1.18 \pm 0.335$ & $1.20 \pm 0.339$ & $401 \pm 9.87$ & $396 \pm 26.9$ \\
\hline 24 & $1.35 \pm 0.383$ & $1.35 \pm 0.381$ & $350 \pm 70.0$ & $352 \pm 70.4$ \\
\hline 168 & $1.84 \pm 0.520$ & $2.17 \pm 0.615$ & $258 \pm 51.6$ & $218 \pm 43.6$ \\
\hline
\end{tabular}

The neptunium behavior agrees with past experimental observations showing a modest, increasing DF over time. ${ }^{7,8}$ As with the plutonium and strontium results, the presence of the $500 \mathrm{ppm}$ of CSSX solvent has no effect on MST sorption of neptunium within 168 hours. 


\section{Figure 4. ${ }^{237} \mathrm{~Np}$ in Solution Over Time With and Without CSSX Solvent}

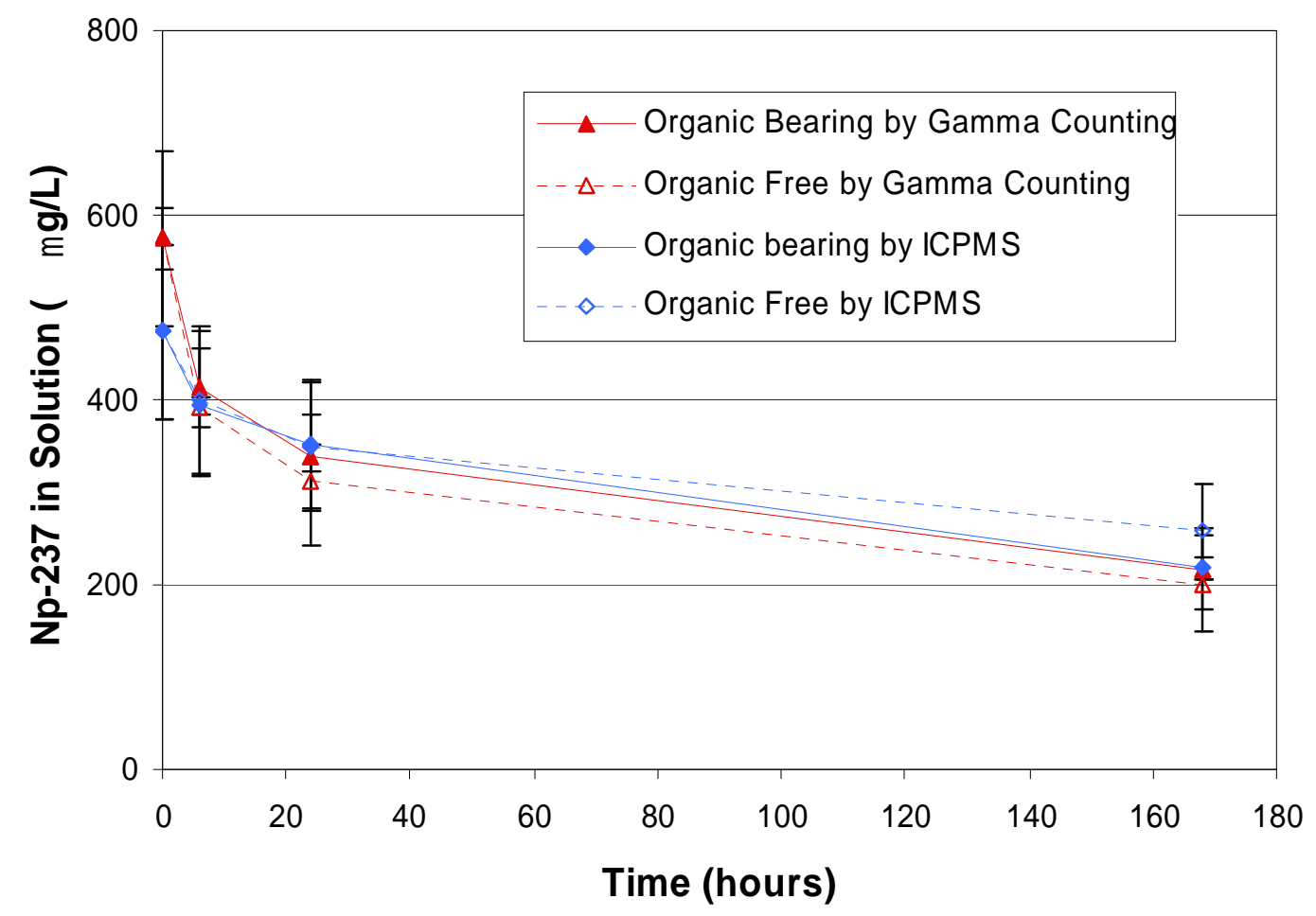

\subsubsection{MST Sorption of Uranium}

Personnel measured ${ }^{238} \mathrm{U}$ in solution by ICPMS. Table 11 displays the collected data. Figure 5 is a graphical representation of the data.

Table 11. ${ }^{238} \mathrm{U}$ DF With and Without CSSX Solvent as Determined by ICPMS

\begin{tabular}{|c|c|c|c|c|}
\hline \multirow{2}{*}{$\begin{array}{c}\text { Time } \\
\text { (hours) }\end{array}$} & \multicolumn{2}{|c|}{${ }^{238} \mathrm{U}$ DF Values } & \multicolumn{2}{c|}{${ }^{238} \mathrm{U} \mu \mathrm{g} / \mathrm{L}$ Values } \\
\cline { 2 - 5 } & No Organic & Organic & No Organic & Organic \\
\hline $6^{*}$ & $1.18 \pm 0.333$ & $1.16 \pm 0.329$ & $8280 \pm 122$ & $8390 \pm 247$ \\
\hline 24 & $1.30 \pm 0.369$ & $1.24 \pm 0.351$ & $7480 \pm 1500$ & $7860 \pm 1570$ \\
\hline 168 & $1.51 \pm 0.427$ & $1.56 \pm 0.441$ & $6460 \pm 1290$ & $6260 \pm 1250$ \\
\hline
\end{tabular}

* The 6 hour samples are triplicates; other samples are single analyses 


\section{Figure 5. ${ }^{238} \mathrm{U}$ In Solution Over Time With and Without CSSX Solvent}

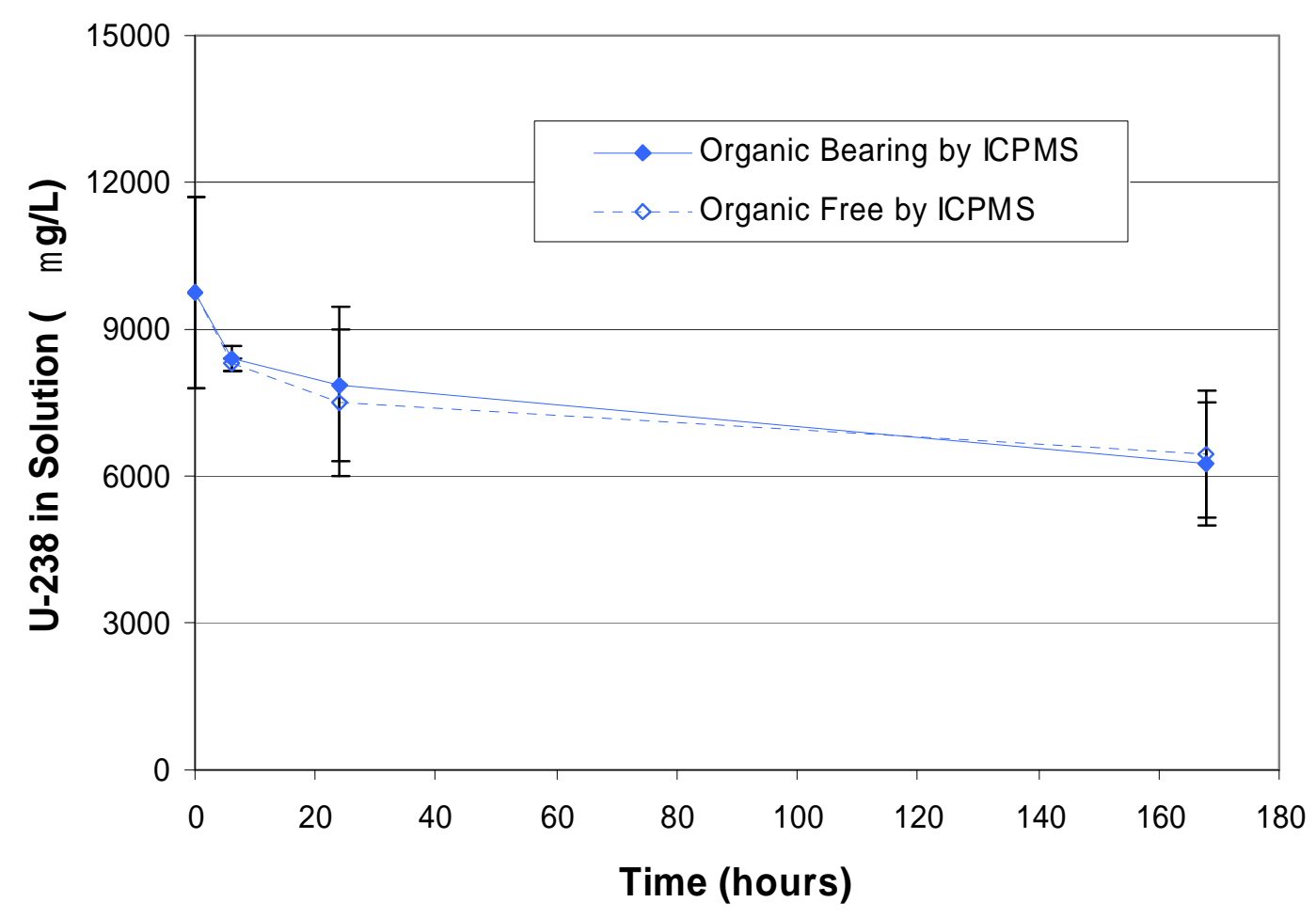

As with the other sorbates, we see that uranium removal increases with time, which agrees with previous findings. ${ }^{78}$ Examination of the measurements for the organicbearing and organic-free experiments shows no statistical difference between the two sets of values. We conclude that the presence of the $500 \mathrm{ppm}$ of CSSX solvent has no effect on MST sorption of uranium within 168 hours.

\subsubsection{MST Sorption of Protactinium}

Personnel measured ${ }^{233} \mathrm{~Pa}$ (most likely in a +5 oxidation state) in solution by Gamma Counting. Calculation of the protactinium removal requires correction for the ingrowth of ${ }^{233} \mathrm{~Pa}$ from ${ }^{237} \mathrm{~Np}$. Appendix III details the required calculations. Table 12 displays the collected data. Figure 6 shows a graphical representation of the data.

Unlike other elements described in this document, there is little data on MST removal of protactinium. The initial DF of $\sim 6$ increases to 35 over the one-week experiment. 
Table 12. ${ }^{233} \mathrm{~Pa}$ With and Without CSSX Solvent as Determined by Gamma Counting

\begin{tabular}{|c|c|c|c|c|}
\hline \multirow{2}{*}{$\begin{array}{c}\text { Time } \\
\text { (hours) }\end{array}$} & \multicolumn{2}{|c|}{${ }^{233} \mathrm{~Pa}$ DF Values } & \multicolumn{2}{c|}{${ }^{233} \mathrm{~Pa} \mu \mathrm{g} / \mathrm{L}$ Values } \\
\hline & No Organic & Organic & No Organic & Organic \\
\hline $6^{*}$ & $6.06 \pm 0.733$ & $5.52 \pm 0.580$ & $3.06( \pm 0.365) \mathrm{E}-06$ & $3.36( \pm 0.217) \mathrm{E}-06$ \\
\hline 24 & $7.09 \pm 0.638$ & $6.94 \pm 0.638$ & $2.62( \pm 0.149) \mathrm{E}-06$ & $2.67( \pm 0.160) \mathrm{E}-06$ \\
\hline 168 & $35.0 \pm 4.22$ & $\mathrm{NA}^{* *}$ & $5.31( \pm 0.523) \mathrm{E}-07$ & $\mathrm{NA}^{* *}$ \\
\hline
\end{tabular}

* The 6 hour samples are triplicates; other samples are single analyses

** Data point did not give a meaningful result due to a high background count.

Comparison of the measurements for the organic-bearing and organic-free solutions shows no statistical difference between the two sets of values. We conclude that the presence of the $500 \mathrm{ppm}$ of CSSX solvent has no effect on MST removal of protactinium at 6 or 24 hours.

Figure 6. ${ }^{233}$ Pa Decontamination over Time DF Over Time With and Without CSSX Solvent

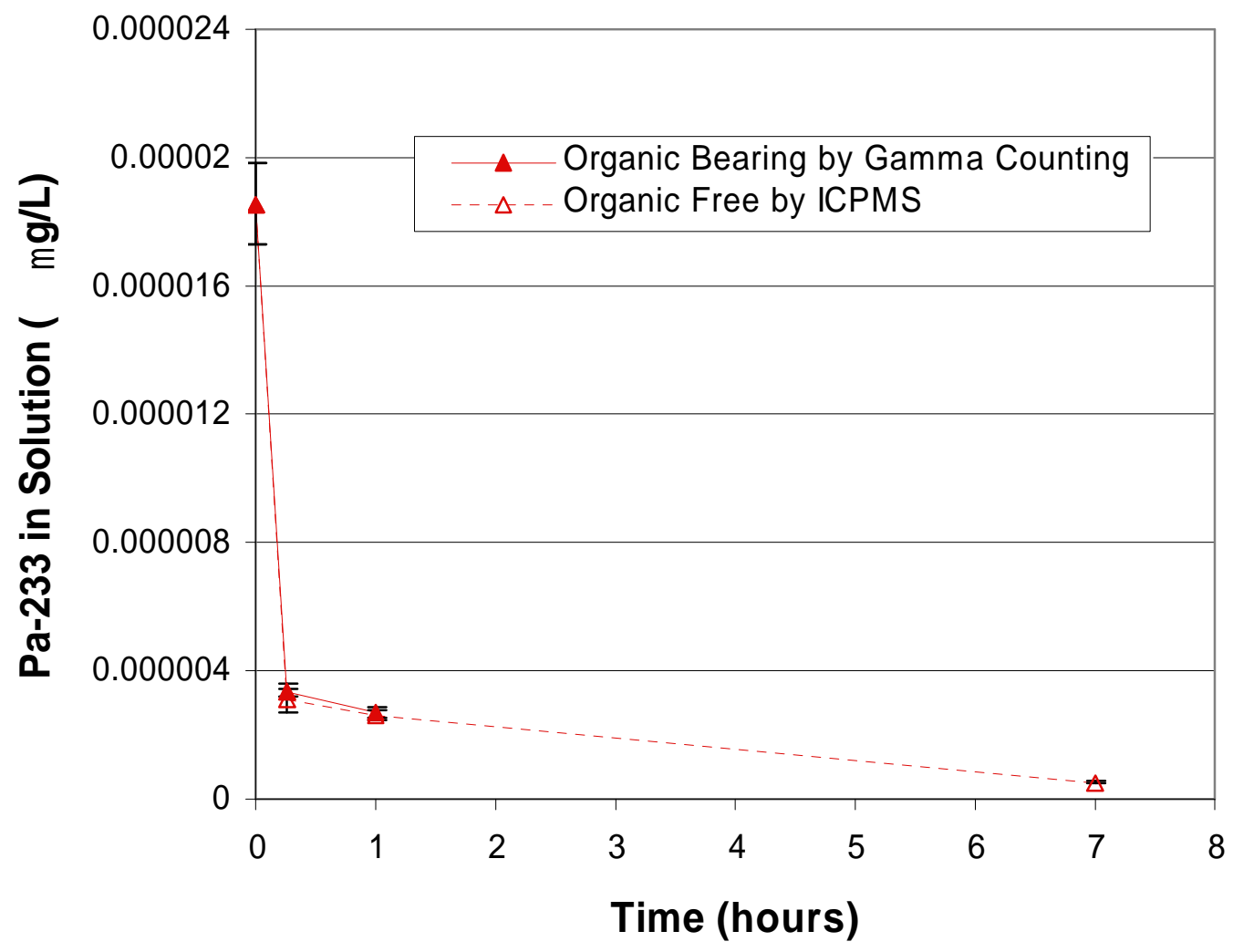




\subsection{Effect of MST Reuse}

4.2.1 Plutonium Removal during SWPF Process Sequence

Table 13 shows the ${ }^{238} \mathrm{Pu}$ (Gamma Counting) or ${ }^{239} \mathrm{Pu}$ (ICPMS) in solution as monitored by PuTTa and ICPMS.

The plutonium concentration of the solution without MST (control) remained unchanged throughout the duration of the experiment, indicating a chemically stable solution without sorption to the container or precipitation.

Figure 7 shows the effect of three sequential additions of fresh MST, with intermediate removal by filtration, on a simulant solution (i.e., Strikes B, C, and E). The replicates give excellent agreement. In each case, addition of MST yielded a reduction in the amount of plutonium in solution. The first strike (B) gave a step-wise DF of $\sim 10$. The second strike $(\mathrm{C})$ gave a step-wise DF of $\sim 10$. The third strike (E) gave a step-wise DF of $\sim 7$.

Table 13. MST Sorption of Plutonium

\begin{tabular}{|c|c|c|c|}
\hline Control & $\begin{array}{c}\text { Time } \\
\text { (h) }\end{array}$ & $\begin{array}{c}\text { PuTTa } \\
\text { Supernate } \\
{ }^{238} \mathrm{Pu}(\mu \mathrm{g} / \mathrm{L})\end{array}$ & $\begin{array}{c}\text { ICPMS } \\
\text { Supernate } \\
{ }^{239} \mathrm{Pu}(\mu \mathrm{g} / \mathrm{L})\end{array}$ \\
\hline 0 & 0 & $1.55 \pm 0.0755$ & $93.9 \pm 18.8$ \\
\hline 24 & 24 & $1.56 \pm 0.0807$ & $112 \pm 22.3$ \\
\hline 48 & 48 & $1.55 \pm 0.0732$ & $89.0 \pm 17.8$ \\
\hline 72 & 72 & $1.53 \pm 0.0800$ & $105 \pm 21.1$ \\
\hline 96 & 96 & $1.64 \pm 0.0829$ & $79.0 \pm 15.8$ \\
\hline $\begin{array}{l}\text { Sequential } \\
\text { MST } \\
\text { Additions } \\
\end{array}$ & $\begin{array}{c}\text { Strike } \\
\quad \#\end{array}$ & $\begin{array}{l}\text { Supernate } \\
{ }^{238} \mathrm{Pu}(\mu \mathrm{g} / \mathrm{L})\end{array}$ & $\begin{array}{c}\text { Supernate } \\
{ }^{239} \mathrm{Pu}(\mu \mathrm{g} / \mathrm{L})\end{array}$ \\
\hline 1 & $\mathrm{~B}$ & $0.156 \pm 0.00806$ & $<60$ \\
\hline 2 & $\mathrm{~B}$ & $0.155 \pm 0.00799$ & $<60$ \\
\hline 1 & $\mathrm{C}$ & $0.0169 \pm 0.000993$ & $<40$ \\
\hline 2 & $\mathrm{C}$ & $0.0141 \pm 0.00103$ & $<40$ \\
\hline 1 & $\mathrm{E}$ & $0.00231 \pm 0.000303$ & $<40$ \\
\hline 2 & $E$ & $0.00204 \pm 0.000396$ & $<40$ \\
\hline $\begin{array}{c}\text { Re-Use of } \\
\text { MST }\end{array}$ & $\begin{array}{c}\text { Strike } \\
\#\end{array}$ & $\begin{array}{c}\text { Supernate } \\
{ }^{238} \mathrm{Pu}(\mu \mathrm{g} / \mathrm{L})\end{array}$ & $\begin{array}{c}\text { Supernate } \\
{ }^{239} \mathrm{Pu}(\mu \mathrm{g} / \mathrm{L})\end{array}$ \\
\hline 1 & $\mathrm{C}$ & $0.0169 \pm 0.000993$ & $<40$ \\
\hline 2 & $\mathrm{C}$ & $0.0141 \pm 0.00103$ & $<40$ \\
\hline 1 & $\mathrm{D}$ & $0.321 \pm 0.0171$ & $44.8 \pm 8.96$ \\
\hline 2 & $\mathrm{D}$ & $0.308 \pm 0.0150$ & $<40$ \\
\hline
\end{tabular}


Figure 7. The Effect of Three Fresh MST Additions on ${ }^{238} \mathrm{Pu}$ (PuTTa)

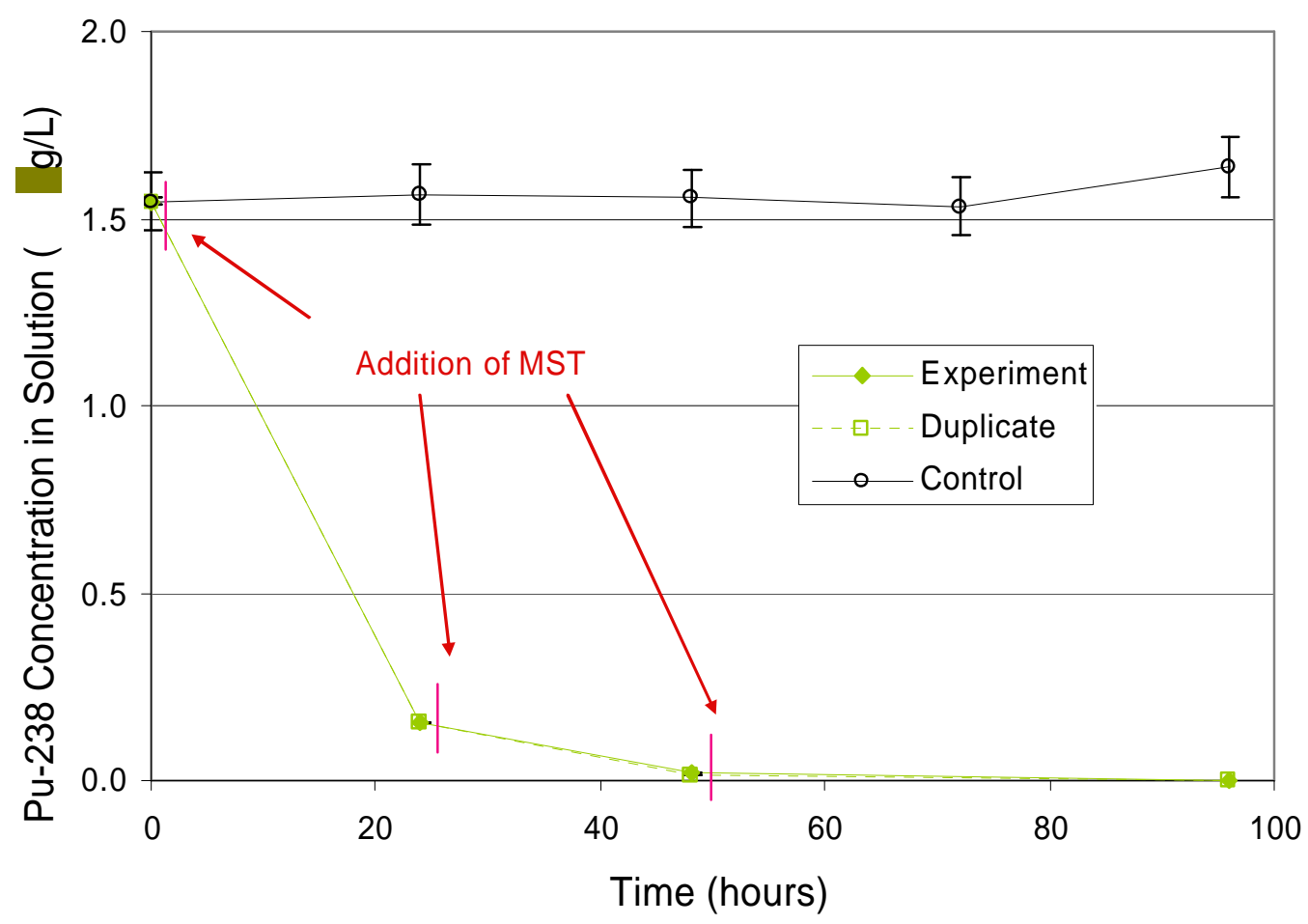

Table 14 shows the impact of re-using MST (i.e., Strikes C and D of Table 10). Although the MST appears to lose sorption capacity after recovery, the amount of plutonium removed from solution remains appreciable. While the first use of the MST gave a DF of $\sim 10$, the second use yielded a DF of $\sim 5$.

Except for the $\mu \mathrm{g} / \mathrm{g}$ results, the values in the table are calculated based on the quantity of plutonium removed from solution and the quantity of MST added to each test bottle. The $\mu \mathrm{g} / \mathrm{g}$ results are calculated from analyses of the digested MST solids recovered at the end of the last sequential experiments. Loading values are provided on weight percent (wt \%) and $\mu \mathrm{g} \mathrm{Pu} / \mathrm{g}$ MST bases.

For the wt $\%$ basis, the loading is calculated including the masses of all fissile elements (equation 1).

$$
W t \%=100 * \frac{g P u}{g P u+g U+g N p+g S r+g M S T}
$$


WSRC-STI-2006-00012, REV. 0

Table 14. MST Loading of Plutonium from Reuse

\begin{tabular}{|c|c|c|c|c|}
\hline $\begin{array}{c}\text { Re-Use of } \\
\text { MST }\end{array}$ & Strike \# & $\begin{array}{c}\text { Pu Loading } \\
(\mathbf{w t} \%)\end{array}$ & $\begin{array}{c}\text { PuTTa } \\
\text { MST Loading } \\
\text { Total Pu }(\mu \mathbf{g} / \mathbf{g} \text { MST })\end{array}$ & DF \\
\hline 1 & $\mathrm{C}$ & 0.00159 & $8.21 \mathrm{E}+00$ & $10.8 \pm 1.12$ \\
\hline 2 & $\mathrm{C}$ & 0.00172 & $8.83 \mathrm{E}+00$ & $12.2 \pm 1.48$ \\
\hline 1 & $\mathrm{D}$ & 0.0162 & $1.69 \mathrm{E}+02$ & $4.61 \pm 0.243$ \\
\hline 2 & $\mathrm{D}$ & 0.0166 & $1.73 \mathrm{E}+02$ & $4.99 \pm 0.251$ \\
\hline
\end{tabular}

The reader must recall that the first strike (Strike C) used a simulant already depleted, while the second strike (Strike D) involved a fresh simulant. The difference in the initial radionuclide composition in the simulants results in the differing DF values and loading.

\subsubsection{Plutonium Mass Balance}

One check of internal data consistency is to determine the sum of plutonium sorbed based on the analytical results from the filtrate and compare with the amount of plutonium measured on the digested MST solids. Table 12 contains the data. For the plutonium in the supernate before MST addition, the value is the average of four samples (i.e., three from equilibration and one initial sample).

For the plutonium on the digested MST, the amount of plutonium captured on all the MST is corrected for the recovered quantity of MST (85-94\% depending on which experiment). In Table 15, the \% Mass Balance term is calculated by dividing the sum of [plutonium measured on the MST and the plutonium left in the supernate after the addition of MST] by the sum of [amount of plutonium present in the bottles used in Strikes C and D before the addition of MST]. The mass balance averaged 106\% for plutonium.

Table 15. ${ }^{238} \mathrm{Pu}$ Mass Balance

\begin{tabular}{|c|c|c|c|c|}
\hline Experiment & $\begin{array}{c}{ }^{238} \mathbf{P u} \text { in } \\
\text { Supernate } \\
\text { Before MST } \\
(\mu \mathbf{g})\end{array}$ & $\begin{array}{c}{ }^{238} \mathbf{P u} \text { in } \\
\text { Supernate } \\
\text { after MST } \\
(\mu \mathbf{g})\end{array}$ & $\begin{array}{c}{ }^{238} \mathbf{P u} \text { on } \\
\text { MST Solids } \\
(\mu \mathbf{g})\end{array}$ & $\begin{array}{c}\text { \% Mass } \\
\text { Balance } \\
(\boldsymbol{\%})\end{array}$ \\
\hline PuTTA & & & & \\
\hline 1 & 1.71 & 0.340 & 1.43 & 104 \\
\hline 2 & 1.71 & 0.322 & 1.51 & 108 \\
\hline
\end{tabular}


4.2.3 Uranium Removal during SWPF Process Sequence Personnel measured ${ }^{238} \mathrm{U}$ in solution by ICPMS (Table 16). We used ${ }^{238} \mathrm{U}$ instead of ${ }^{235 / 8} \mathrm{U}$ due to several ${ }^{235} \mathrm{U}$ data points being less than detection limits.

Table 16. MST Performance on ${ }^{238} \mathrm{U}$

\begin{tabular}{|c|c|c|}
\hline Control & $\begin{array}{c}\text { Time } \\
(\mathbf{h})\end{array}$ & $\begin{array}{c}\text { ICPMS } \\
\text { Supernate } \\
{ }_{\mathbf{2 3 8}} \mathbf{U}(\boldsymbol{\mu} \mathbf{g} / \mathbf{L})\end{array}$ \\
\hline 0 & 0 & $13,800 \pm 2,760$ \\
\hline 24 & 24 & $14,700 \pm 2,940$ \\
\hline 48 & 48 & $12,900 \pm 2,580$ \\
\hline 72 & 72 & $13,500 \pm 2,700$ \\
\hline 96 & 96 & $13,900 \pm 2,790$ \\
\hline $\begin{array}{c}\text { Sequential } \\
\text { MST } \\
\text { Additions }\end{array}$ & Strike \# & $\begin{array}{c}\text { Supernate } \\
{ }_{\mathbf{2 3}} \mathbf{U}(\boldsymbol{\mu} \mathbf{g} / \mathbf{L})\end{array}$ \\
\hline 1 & $\mathrm{~B}$ & $12,200 \pm 2,430$ \\
\hline 2 & $\mathrm{~B}$ & $11,800 \pm 2,360$ \\
\hline 1 & $\mathrm{C}$ & $9,420 \pm 1,880$ \\
\hline 2 & $\mathrm{C}$ & $10,100 \pm 2,010$ \\
\hline 1 & $\mathrm{E}$ & $8,080 \pm 1,620$ \\
\hline 2 & $\mathrm{E}$ & $8,420 \pm 1,680$ \\
\hline Re-Use of & Strike \# & $\begin{array}{c}\text { Supernate } \\
\mathbf{2 3 8} \mathbf{U}(\boldsymbol{\mu} \mathbf{g} / \mathbf{L})\end{array}$ \\
\hline MST & $\mathrm{C}$ & $9,420 \pm 1,880$ \\
\hline 1 & $\mathrm{C}$ & $10,100 \pm 2,010$ \\
\hline 2 & $\mathrm{D}$ & $12,900 \pm 2,590$ \\
\hline 1 & $\mathrm{D}$ & $13,300 \pm 2,660$ \\
\hline 2 & &
\end{tabular}

The uranium concentration of the control solution without MST remained stable throughout the duration of the experiment, indicating a chemically stable solution without sorption to the container or precipitation. As the supernate values are small, and the uncertainty of each measurement is $20 \%$, we can only firmly say that by the third MST strike do we observe a statistically significant removal of uranium compared to the control.

Figure 8 shows the effect of three sequential additions of MST, with intermediate removal by filtration, on a simulant solution (i.e., Strikes B, C, and E). The duplicate experiments gave excellent agreement. In each case, addition of MST yielded a reduction in the amount of uranium in solution. The first MST addition gave a step-wise 
DF of 1.15. The second addition gave a step-wise DF of 1.23. The third addition yielded a step-wise DF of 1.18 .

Figure 8. The Effect of Three Fresh MST Additions on ${ }^{238} \mathbf{U}$

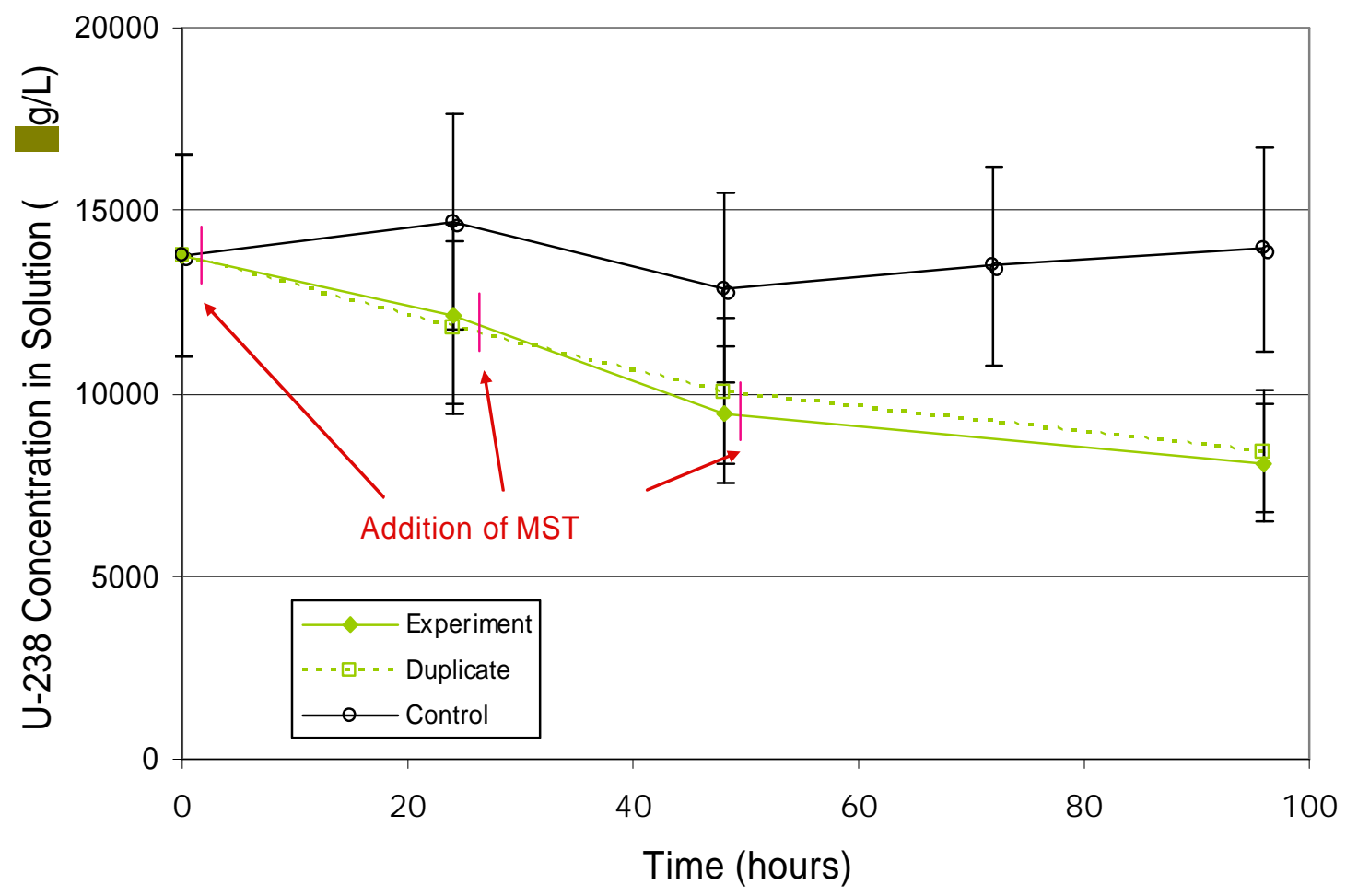

Table 17 shows the impact of re-using MST (i.e., Strikes C and D of Table 16). Although the MST loses sorption capacity after recovery, comparable uranium removal from solution persists in the second use.

Table 17. MST Loading of ${ }^{238} \mathrm{Pu}$ from Reuse

\begin{tabular}{|c|c|c|c|c|}
\hline $\begin{array}{l}\text { Re-Use } \\
\text { of MST }\end{array}$ & $\begin{array}{c}\text { Strike } \\
\quad \#\end{array}$ & $\begin{array}{c}{ }^{238} \text { U Loading } \\
\text { (wt \%) }\end{array}$ & $\begin{array}{c}\text { ICPMS } \\
\text { MST Loading } \\
{ }^{238} \mathrm{U}(\mu \mathrm{g} / \mathrm{g} \text { MST })\end{array}$ & DF \\
\hline 1 & $\mathrm{C}$ & 0.665 & $3.43 \mathrm{E}+03$ & $1.13 \pm 0.226$ \\
\hline 2 & $\mathrm{C}$ & 0.418 & $2.15 \mathrm{E}+03$ & $1.17 \pm 0.234$ \\
\hline 1 & $\mathrm{D}$ & 0.855 & $8.96 \mathrm{E}+03$ & $1.07 \pm 0.214$ \\
\hline 2 & $\mathrm{D}$ & 0.527 & $5.51 \mathrm{E}+03$ & $1.04 \pm 0.208$ \\
\hline
\end{tabular}


The reader must recall that the first strike $(\mathrm{C})$ used a simulant already depleted, while the second strike (D) involved a fresh simulant. The difference in the simulants accounts for the different DF and mass loading.

\subsubsection{Uranium Mass Balance}

One check of internal data consistency is to determine the sum of uranium sorbed based on the analytical results from the filtrate and compare with the amount of uranium measured on the digested MST solids. Table 18 contains the data. For the uranium in the supernate before MST addition, the value is the average of four samples (i.e., three from equilibration and one initial sample). In this case, we use only ${ }^{238} \mathrm{U}$ data to avoid using less-than values present in some of the ${ }^{235} \mathrm{U}$ data.

For the uranium on the digested MST, the amount of uranium captured on all the MST is corrected for the recovered quantity of MST (85-94\% depending on which experiment). In Table 15, the \% Mass Balance term is calculated by dividing the sum of [uranium measured on the MST and the uranium left in the supernate after the addition of MST] by the sum of [amount of uranium present in the bottles used in strikes C and D before the addition of MST]. The mass balance averaged $99.5 \%$ for uranium.

Table 18. ${ }^{238} \mathrm{U}$ Mass Balance

\begin{tabular}{|c|c|c|c|c|}
\hline Experiment & $\begin{array}{c}{ }^{238} \mathrm{U} \text { in } \\
\text { Supernate } \\
\text { Before MST } \\
(\mu \mathrm{g})\end{array}$ & $\begin{array}{c}{ }^{238} \mathrm{U} \text { in } \\
\text { Supernate } \\
\text { after MST } \\
(\mu \mathrm{g})\end{array}$ & $\begin{array}{c}{ }^{238} \mathrm{U} \text { on MST } \\
\text { Solids } \\
(\mu \mathrm{g})\end{array}$ & $\begin{array}{c}\% \text { Mass } \\
\text { Balance } \\
(\%)\end{array}$ \\
\hline \multicolumn{5}{|l|}{ ICPMS } \\
\hline 1 & $2.60 \mathrm{E}+04$ & $2.25 \mathrm{E}+04$ & $3.27 \mathrm{E}+03$ & 98.9 \\
\hline 2 & $2.60 \mathrm{E}+04$ & $2.27 \mathrm{E}+04$ & $3.30 \mathrm{E}+03$ & 100 \\
\hline
\end{tabular}

\subsubsection{Strontium Removal during SWPF Sequence}

Analysts measured ${ }^{85} \mathrm{Sr}$ by Gamma Counting and cold $\left({ }^{88} \mathrm{Sr}\right.$ ) strontium by ICPMS (Table 19). The strontium concentrations of the control solution without MST remained stable throughout the duration of the experiment, indicating a chemically stable solution without sorption to the container or precipitation. 
Table 19. MST Sorption of ${ }^{85} \mathrm{Sr}$

\begin{tabular}{|c|c|c|c|}
\hline Control & $\begin{array}{l}\text { Time } \\
\text { (h) }\end{array}$ & $\begin{array}{c}\text { Gamma } \\
\text { Counting } \\
\text { Supernate } \\
{ }^{85} \mathrm{Sr}(\mathrm{dpm} / \mathrm{mL})\end{array}$ & $\begin{array}{c}\text { ICPMS } \\
\text { Supernate } \\
{ }^{88} \operatorname{Sr}(\mu \mathrm{g} / \mathrm{L})\end{array}$ \\
\hline 0 & 0 & $56500 \pm 1100$ & $9270 \pm 1850$ \\
\hline 24 & 24 & $55000 \pm 940$ & $9470 \pm 1890$ \\
\hline 48 & 48 & $55800 \pm 954$ & $9200 \pm 1840$ \\
\hline 72 & 72 & $53700 \pm 919$ & $9100 \pm 1820$ \\
\hline 96 & 96 & $56000 \pm 957$ & $9370 \pm 1870$ \\
\hline $\begin{array}{l}\text { Sequential } \\
\text { MST } \\
\text { Additions }\end{array}$ & $\begin{array}{c}\text { Strike } \\
\quad \#\end{array}$ & $\begin{array}{c}\text { Supernate } \\
{ }^{85} \mathrm{Sr}(\mathrm{dpm} / \mathrm{mL})\end{array}$ & $\begin{array}{l}\text { Supernate } \\
{ }^{88} \mathrm{Sr}(\mu \mathrm{g} / \mathrm{L})\end{array}$ \\
\hline 1 & B & $5160 \pm 156$ & $889 \pm 178$ \\
\hline 2 & $\mathrm{~B}$ & $4500 \pm 96.2$ & $867 \pm 173$ \\
\hline 1 & $\mathrm{C}$ & $45.4 \pm 10.6$ & $<>72.6$ \\
\hline 2 & $\mathrm{C}$ & $43.3 \pm 8.66$ & $<72.6$ \\
\hline 1 & $\mathrm{E}$ & $<29.8$ & $<72.6$ \\
\hline 2 & $\mathrm{E}$ & $<44.6$ & $<72.6$ \\
\hline $\begin{array}{c}\text { Re-Use of } \\
\text { MST }\end{array}$ & $\begin{array}{c}\text { Strike } \\
\#\end{array}$ & $\begin{array}{c}\text { Supernate } \\
{ }^{85} \mathrm{Sr}(\mathrm{dpm} / \mathrm{mL})\end{array}$ & $\begin{array}{l}\text { Supernate } \\
{ }^{88} \operatorname{Sr}(\mu \mathrm{g} / \mathrm{L})\end{array}$ \\
\hline 1 & $\mathrm{C}$ & $45.4 \pm 10.6$ & $<72.6$ \\
\hline 2 & $\mathrm{C}$ & $43.3 \pm 8.66$ & $<72.6$ \\
\hline 1 & $\mathrm{D}$ & $11600 \pm 216$ & $2040 \pm 408$ \\
\hline 2 & D & $10100 \pm 191$ & $1840 \pm 368$ \\
\hline
\end{tabular}

Figure 9 shows the effect of three sequential additions of MST, with intermediate removal by filtration, on the ${ }^{85} \mathrm{Sr}$ in the simulant solution (i.e., Strikes B, C, and E). The cold strontium dipped below detection limit quickly, so we use the ${ }^{85} \mathrm{Sr}$ data when discussing DF values. The duplicate experiments give excellent agreement. The first two additions of MST yielded a reduction in the amount of ${ }^{85} \mathrm{Sr}$ in solution. However, after the second addition the amount of ${ }^{85} \mathrm{Sr}$ present approaches the analytical detection limit. Hence, the efficiency of MST sorption for ${ }^{85} \mathrm{Sr}$ in the third sequential contact is indeterminate. 


\section{Figure 9. The Effect of Three Fresh MST Additions on ${ }^{85} \mathrm{Sr}$}

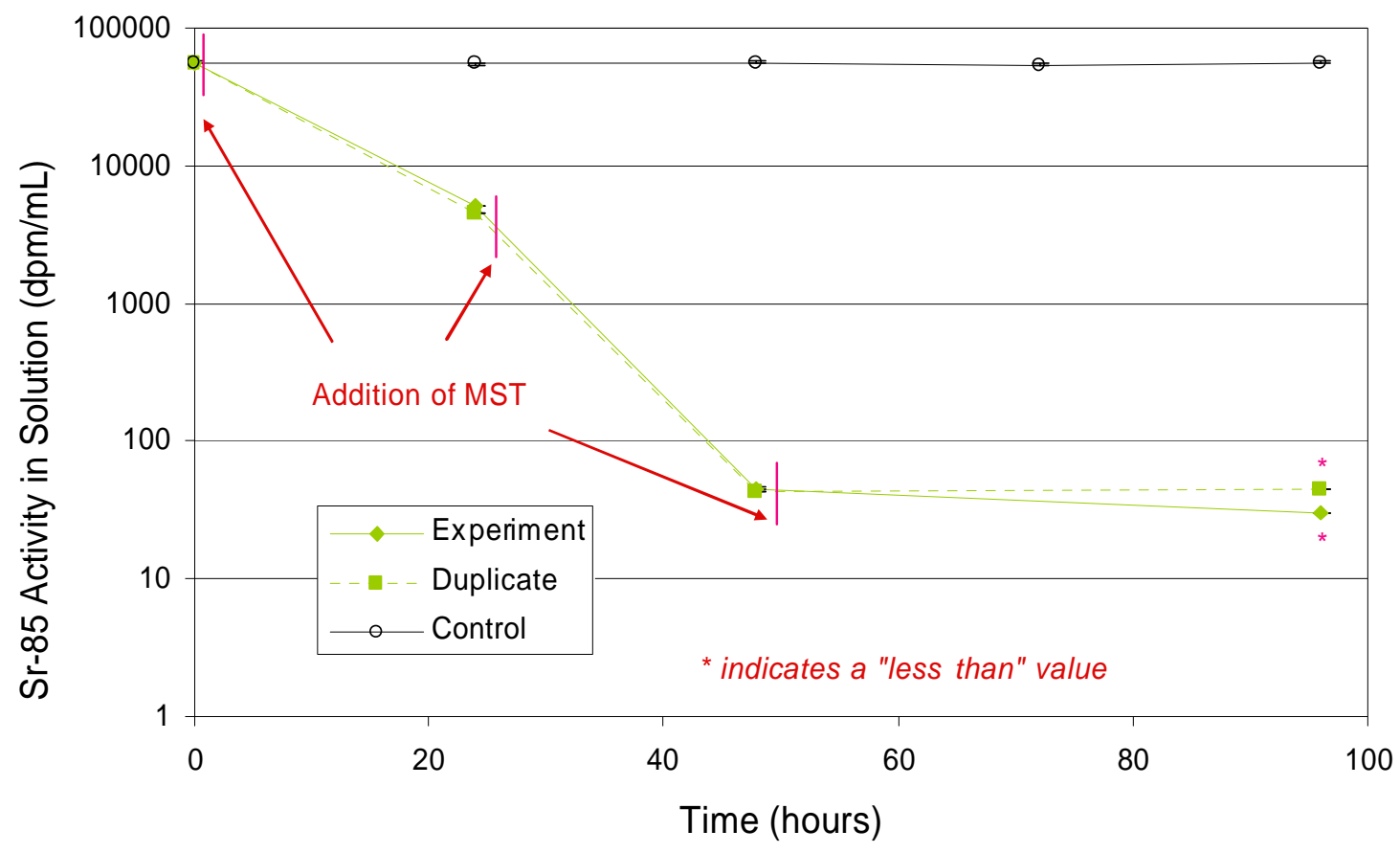

Table 20 shows the impact of re-using MST (i.e., Strikes C and D of Table 16). For the purposes of MST loading and mass balance, we use the decontamination factors derived from ${ }^{85} \mathrm{Sr}$ data and apply them to the total strontium data.

Although the MST loses sorption capacity after recovery, the amount of total strontium (in this case, we use natural ${ }^{88} \mathrm{Sr}$ as the analyte from the ICPMS data) removed from solution remains appreciable. While the first use of the MST gave an average DF of 11.8 , the second use gave an average DF of 5.23.

Table 20. MST Loading of Total Strontium from Reuse

\begin{tabular}{|c|c|c|c|}
\hline $\begin{array}{c}\text { Re-Use } \\
\text { of MST }\end{array}$ & $\begin{array}{c}\text { Strike } \\
\#\end{array}$ & $\begin{array}{c}\text { ICPMS } \\
\text { MST Loading } \\
\text { Total } \mathbf{S r}(\mu \mathbf{g} / \mathbf{g} \text { MST })\end{array}$ & DF \\
\hline 1 & C & $2.11 \mathrm{E}+03$ & $114 \pm 15.1$ \\
\hline 2 & $\mathrm{C}$ & $1.82 \mathrm{E}+03$ & $104 \pm 11.5$ \\
\hline 1 & $\mathrm{D}$ & $3.91 \mathrm{E}+04$ & $4.87 \pm 0.0906$ \\
\hline 2 & $\mathrm{D}$ & $3.99 \mathrm{E}+04$ & $5.59 \pm 0.106$ \\
\hline
\end{tabular}

The reader must recall that the first strike (C) used a simulant already depleted, while the second strike (D) involved a fresh simulant. The difference in the simulants results in the reason for the difference in DF and mass loading. 


\subsubsection{Strontium Mass Balance}

One check of internal data consistency is to determine the sum of total strontium sorbed based on the analytical results from the filtrate and compare with the amount of strontium measured on the digested MST solids. Table 18 contains the data. Again, we apply the DF values derived from ${ }^{85} \mathrm{Sr}$ to the total strontium data. For the strontium in the supernate before MST addition, the value is the average of four samples (i.e., three from equilibration and one initial sample).

For the strontium on the digested MST, the amount of strontium captured on all the MST is corrected for the recovered quantity of MST (85-94\% depending on which experiment). In Table 21, the \% Mass Balance term is calculated by dividing the sum of [strontium measured on the MST and the strontium left in the supernate after the addition of MST] by the sum of [amount of strontium present in the bottles used in Strikes C and D before the addition of MST]. The mass balance averaged 108\% for strontium.

Table 21. Strontium Mass Balance

\begin{tabular}{|c|c|c|c|c|}
\hline Experiment & $\begin{array}{c}\text { Sr in } \\
\text { Supernate } \\
\text { Before MST } \\
(\mu \mathbf{g})\end{array}$ & $\begin{array}{c}\text { Sr in } \\
\text { Supernate } \\
\text { after MST } \\
(\mu \mathbf{g})\end{array}$ & $\begin{array}{c}\text { Sr on MST } \\
\text { Solids } \\
(\mu \mathbf{g})\end{array}$ & $\begin{array}{c}\boldsymbol{\%} \text { Mass } \\
\text { Balance } \\
(\boldsymbol{\%})\end{array}$ \\
\hline ICPMS & & & & \\
\hline 1 & $1.02 \mathrm{E}+04$ & $2.04 \mathrm{E}+03$ & $8.96 \mathrm{E}+03$ & 109 \\
\hline 2 & $1.02 \mathrm{E}+04$ & $1.84 \mathrm{E}+03$ & $9.00 \mathrm{E}+03$ & 107 \\
\hline
\end{tabular}

4.2.7 Neptunium Removal during SWPF Process Sequence Researchers measured ${ }^{237} \mathrm{~Np}$ in solution ICPMS (Table 22) for the SWPF process sequence. The variance between measurements and between replicate experiments proved large relative to any sorption onto MST. Many of the experimental data after treatment with MST fell below detection limits. Hence, few conclusions are possible for neptunium chemistry on MST.

The neptunium concentration of the control solution without MST remained stable throughout the duration of the experiment, indicating a chemically stable solution without sorption to the container or precipitation. The slight offset after the first equilibrium data point should not be taken as an ingrowth of neptunium into solution. 
Table 22. MST Sorption of ${ }^{237} \mathrm{~Np}$

\begin{tabular}{|c|c|c|}
\hline Control & $\begin{array}{c}\text { Time } \\
(\mathbf{h})\end{array}$ & $\begin{array}{c}\text { ICPMS } \\
\text { Supernate } \\
{ }^{237} \mathbf{N p}(\mu \mathbf{g} / \mathbf{L})\end{array}$ \\
\hline 0 & 0 & $124 \pm 24.8$ \\
\hline 24 & 24 & $173 \pm 34.5$ \\
\hline 48 & 48 & $152 \pm 30.4$ \\
\hline 72 & 72 & $161 \pm 32.1$ \\
\hline 96 & 96 & $158 \pm 31.6$ \\
\hline $\begin{array}{c}\text { Sequential } \\
\text { MST } \\
\text { Additions }\end{array}$ & Strike \# & $\begin{array}{c}\text { Supernate } \\
{ }^{237} \mathbf{N p}(\mu \mathbf{g} / \mathbf{L})\end{array}$ \\
\hline 1 & $\mathrm{~B}$ & $<120$ \\
\hline 2 & $\mathrm{~B}$ & $<120$ \\
\hline 1 & $\mathrm{C}$ & $<40$ \\
\hline 2 & $\mathrm{C}$ & $<40$ \\
\hline 1 & $\mathrm{E}$ & $<40$ \\
\hline 2 & $\mathrm{E}$ & $<40$ \\
\hline $\begin{array}{c}\text { Re-Use of } \\
\text { MST }\end{array}$ & Strike \# & $\begin{array}{c}\text { Supernate } \\
\mathbf{2 3 7} \mathbf{N p}(\mu \mathbf{g} / \mathbf{L})\end{array}$ \\
\hline 1 & $\mathrm{C}$ & $<40$ \\
\hline 2 & $\mathrm{C}$ & $<40$ \\
\hline 1 & $\mathrm{D}$ & $106 \pm 21.1$ \\
\hline 2 & $\mathrm{D}$ & $75.2 \pm 15.0$ \\
\hline
\end{tabular}

Table 23 shows the impact of re-using MST (i.e., Strikes C and D of Table 19). Due to analytical detection limits for this data, we can only calculate values for the second use of the MST. 
WSRC-STI-2006-00012, REV. 0

Table 23. MST Loading of ${ }^{237} \mathrm{~Np}$ from Reuse

\begin{tabular}{|c|c|c|c|}
\hline $\begin{array}{c}\text { Re-Use } \\
\text { of MST }\end{array}$ & $\begin{array}{c}\text { Strike } \\
\#\end{array}$ & $\begin{array}{c}\text { ICPMS } \\
\text { MST Loading } \\
{ }^{237} \mathbf{N p}(\boldsymbol{\mu g} / \mathbf{g} \text { MST })\end{array}$ & DF \\
\hline 1 & $\mathrm{C}$ & NA & NA \\
\hline 2 & $\mathrm{C}$ & NA & NA \\
\hline 1 & D & $>45.9$ & $1.17 \pm 0.234$ \\
\hline 2 & D & $>122$ & $1.65 \pm 0.330$ \\
\hline
\end{tabular}

$\mathrm{NA}=$ unable to calculate due to multiple less-than data points

The reader must recall that the first Strike (C) used a simulant that was already depleted, while the second Strike (D) was on a fresh simulant. Unfortunately, due to predominance of less-than data points, we can make no conclusions on the effect of re-using MST on neptunium removal.

\subsubsection{Neptunium Mass Balance}

Due to the large number of less-than data points, we cannot derive an accurate neptunium mass balance result.

\subsection{Fissile Loading Tests (Multiple Sequential Contact Tests)}

This set of experiments examined five sequential additions (each spaced 24 hours from each other) of the same aliquot of MST to equal volumes of a simulant with elevated concentrations of radionuclides. This test represents the first time the performance of MST has been tested with a simulant with all elevated sorbate concentrations.

\subsubsection{MST Multi-Strike Removal of Plutonium from Solution}

For the sequential fissile loading experiments, researchers measured the ${ }^{239 / 40} \mathrm{Pu}$ in solution by PuTTa and ICPMS (Table 24). Figures 10 (PuTTa) and 11 (ICPMS) contain the graphical representations of the data.

Radionuclide concentrations in the solution without MST remained stable throughout the duration of the experiment, indicating chemical stability and absence of complicating factors such as precipitation or deposition on equipment. The control experiments with a single addition of MST show the intuitive trend expected from a single, long term strike. Both controls show an initial good DF ( 10) at 24 hours, followed by an improved DF through 120 hours. We attribute the wide range in 120 hour DF values (14 to 157) to the almost complete mass depletion of plutonium from solution at that time, which makes analysis difficult.

The results for the first additions of MST (i.e., Experiments A and B) and the 24 hour results for the controls (i.e., Control A and Control B) give essentially the same result. 
This is expected as all four of these bottles at that time experienced the same conditions: a single strike of MST at $0.4 \mathrm{~g} / \mathrm{L}$ removed by filtration after 24 hours.

Table 24. MST Sorption of ${ }^{239 / 40} \mathrm{Pu}$ from Solution

\begin{tabular}{|c|c|c|c|c|c|}
\hline & & \multicolumn{2}{|c|}{ PuTTa } & \multicolumn{2}{|c|}{ ICPMS } \\
\hline Control & $\begin{array}{c}\text { Time } \\
\text { (h) }\end{array}$ & $\begin{array}{c}\text { Supernate } \\
{ }^{239 / 40} \mathbf{P u} \\
(\mu \mathrm{g} / \mathrm{L}) \\
\end{array}$ & DF & $\begin{array}{c}\text { Supernate } \\
{ }^{239} \mathbf{P u} \\
(\mu \mathrm{g} / \mathrm{L})\end{array}$ & DF \\
\hline A & 24 & $77.2 \pm 4.48$ & $10.9 \pm 0.632$ & $103 \pm 20.6$ & $7.53 \pm 1.51$ \\
\hline $\mathrm{B}$ & 24 & $68.0 \pm 3.47$ & $12.4 \pm 0.632$ & $68.0 \pm 13.6$ & $11.3 \pm 2.26$ \\
\hline A & 120 & $9.16 \pm 0.559$ & $91.7 \pm 5.59$ & $57.0 \pm 11.4$ & $13.5 \pm 2.70$ \\
\hline $\mathrm{B}$ & 120 & $5.36 \pm 0.456$ & $157 \pm 13.3$ & $14.4 \pm 2.88$ & $53.8 \pm 10.8$ \\
\hline Blank & $\begin{array}{c}\text { Time } \\
\text { (h) }\end{array}$ & $\begin{array}{c}\text { Supernate } \\
{ }^{239 / 40} \mathbf{P u} \\
(\mu \mathrm{g} / \mathrm{L}) \\
\end{array}$ & DF & $\begin{array}{c}\text { Supernate } \\
{ }^{239} \mathbf{P u} \\
(\mu \mathrm{g} / \mathrm{L})\end{array}$ & DF \\
\hline 0 & 0 & $840 \pm 41.8$ & NA & $841 \pm 168$ & NA \\
\hline 1 & 24 & $791 \pm 37.2$ & NA & $766 \pm 153$ & NA \\
\hline 2 & 96 & $763 \pm 38.2$ & NA & $782 \pm 156$ & NA \\
\hline 3 & 120 & $869 \pm 46.1$ & NA & $790 \pm 158$ & NA \\
\hline Experiment & $\begin{array}{c}\text { Strike } \\
\#\end{array}$ & $\begin{array}{c}\text { Supernate } \\
{ }^{239 / 40} \mathbf{P u} \\
(\mu \mathrm{g} / \mathrm{L}) \\
\end{array}$ & DF & $\begin{array}{c}\text { Supernate } \\
{ }^{239} \mathbf{P u} \\
(\mu \mathrm{g} / \mathrm{L}) \\
\end{array}$ & DF \\
\hline A & 1 & $70.8 \pm 4.67$ & $11.9 \pm 0.785$ & $60.5 \pm 12.1$ & $13.9 \pm 2.78$ \\
\hline B & 1 & $66.4 \pm 3.05$ & $12.7 \pm 0.584$ & $54.4 \pm 10.9$ & $15.5 \pm 3.10$ \\
\hline A & 2 & $18.0 \pm 1.10$ & $46.6 \pm 2.84$ & $31.3 \pm 6.26$ & $24.7 \pm 4.94$ \\
\hline $\mathrm{B}$ & 2 & $13.1 \pm 0.697$ & $63.9 \pm 3.39$ & $24.8 \pm 4.96$ & $31.1 \pm 6.22$ \\
\hline A & 3 & $14.4 \pm 0.775$ & $58.5 \pm 3.16$ & $56.0 \pm 11.2$ & $13.8 \pm 2.76$ \\
\hline B & 3 & $6.87 \pm 0.384$ & $122 \pm 6.83$ & $16.8 \pm 3.36$ & $45.9 \pm 9.18$ \\
\hline A & 4 & $14.3 \pm 1.01$ & $58.8 \pm 4.17$ & $15.3 \pm 3.06$ & $50.5 \pm 10.1$ \\
\hline $\mathrm{B}$ & 4 & $6.93 \pm 0.381$ & $121 \pm 6.66$ & $14.3 \pm 2.86$ & $53.8 \pm 10.8$ \\
\hline A & 5 & $8.63 \pm 0.492$ & $97.4 \pm 5.55$ & $17.3 \pm 3.46$ & $44.6 \pm 8.92$ \\
\hline $\mathrm{B}$ & 5 & $8.49 \pm 0.492$ & $99.0 \pm 5.74$ & $17.6 \pm 3.52$ & $43.8 \pm 8.76$ \\
\hline
\end{tabular}

The Strike \# represents the sequential strikes that occurred 24 hours apart. 
The experimental results for the five sequential experiments show a counter-intuitive trend. Instead of seeing the ability of recovered (or "recycled") MST to sorb plutonium decrease in sequential uses, the MST shows improved sorption capability over the entire experiment. Both PuTTa (Figure 10) and ICPMS (Figure 11) show that when reusing the MST a second and a third time, the MST removes more plutonium from solution than it did in the previous strike. From the third to fifth use, the MST sorbs about the same amount of plutonium from solution. This counter-intuitive trend is also seen for the uranium and neptunium, but not for the strontium data, as shown in later figures.

Figure 10. ${ }^{239 / 40} \mathrm{Pu}$ in Solution from PuTTa Measurements

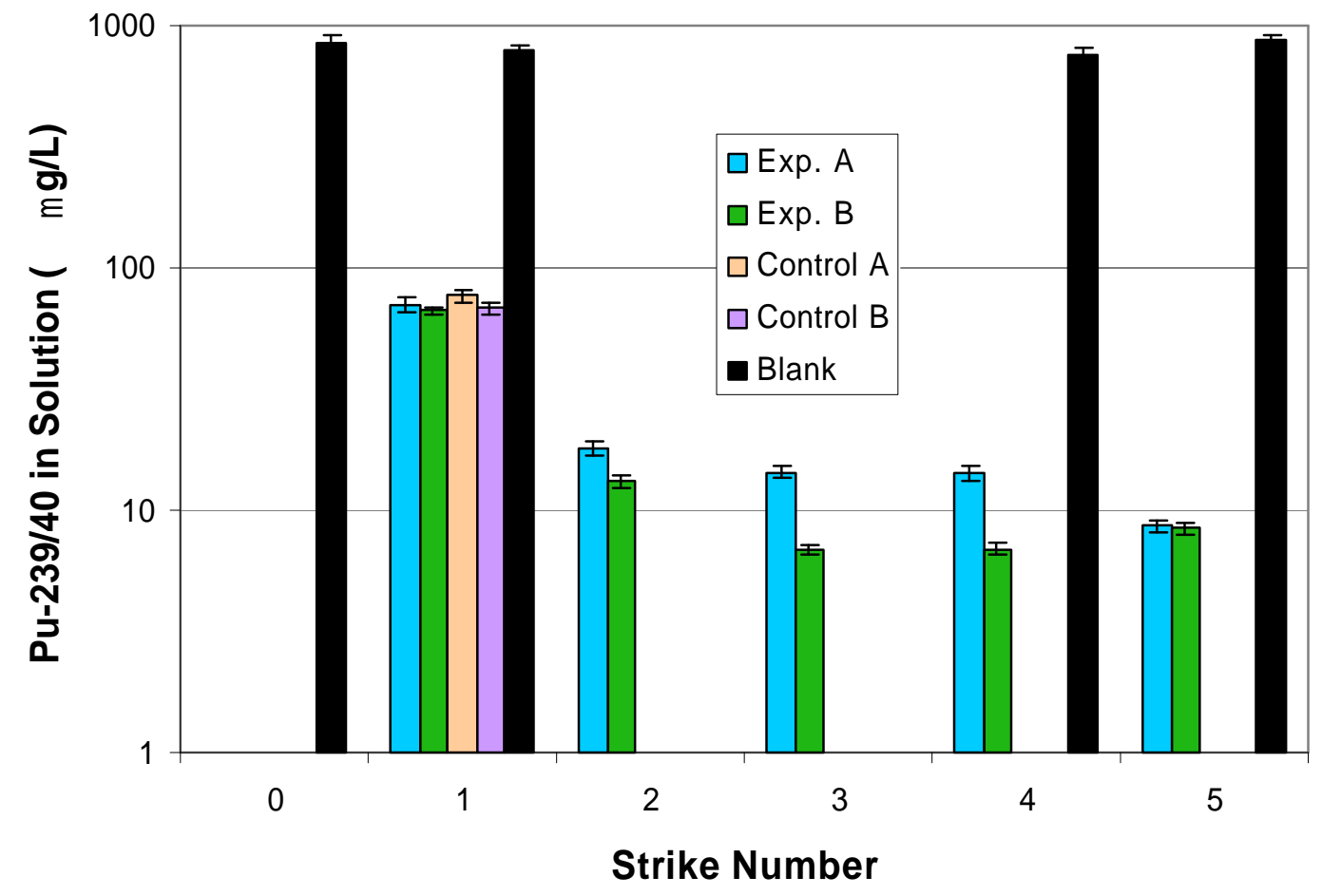

For Figure 10 (and other bar graphs in this document), Strike 0 is the single sample analyzed before the addition of the MST to the first bottle. 


\section{Figure 11. ${ }^{239 / 40} \mathrm{Pu}$ in Solution from ICPMS Measurements}

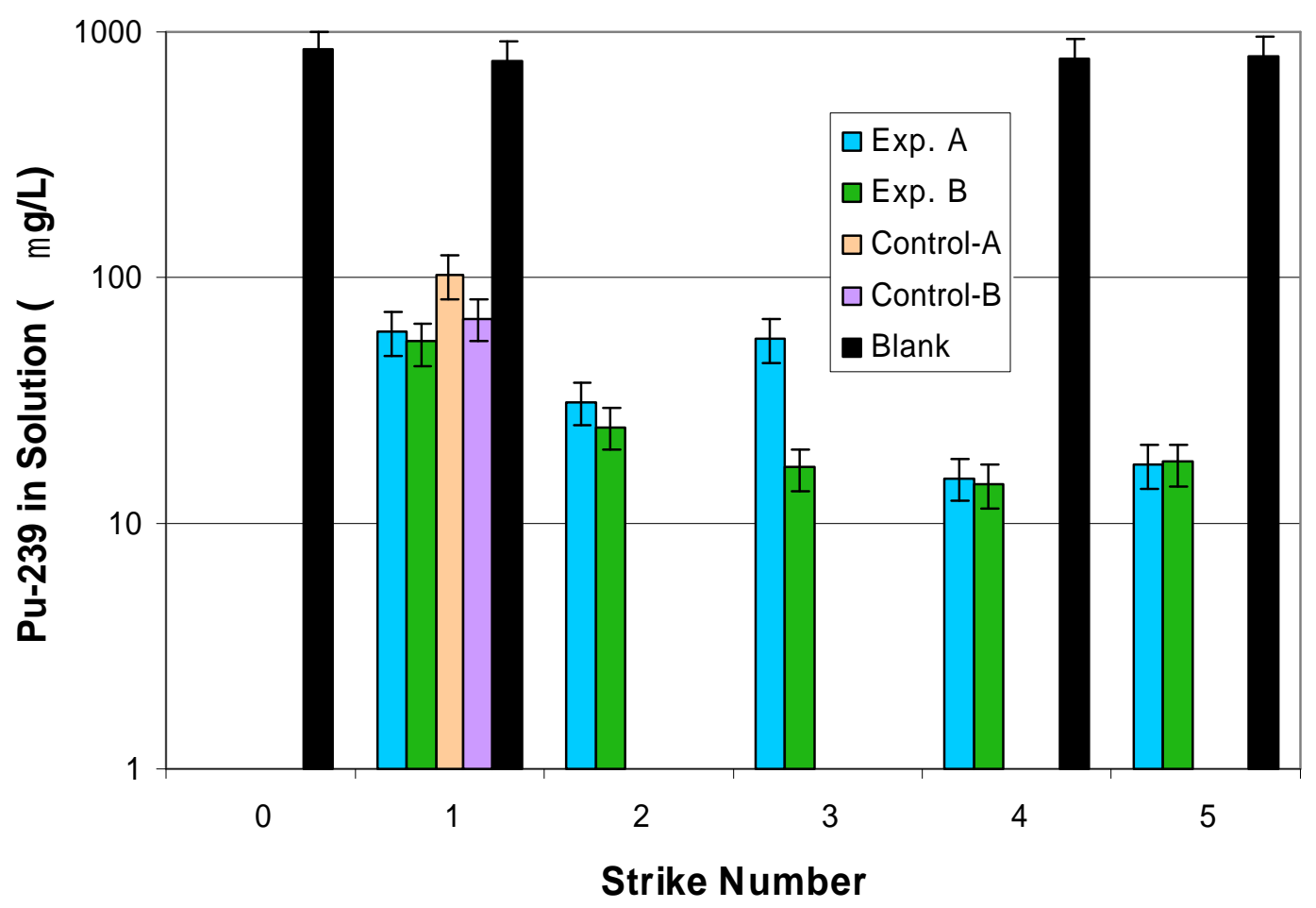

\subsubsection{Cumulative Loading of Plutonium onto MST}

Table 25 provides the measured cumulative loadings of plutonium onto MST for each test. Except for the $\mu \mathrm{g} / \mathrm{g}$ results, the values in the table are calculated based on the quantity of plutonium removed from solution and the quantity of MST added to each test bottle. The $\mu \mathrm{g} / \mathrm{g}$ results are calculated from analyses of the digested MST solids recovered at the end of the last sequential experiments. Loading values are provided on weight percent (wt \%) and $\mu \mathrm{g} \mathrm{Pu} / \mathrm{g}$ MST bases. For the wt \% basis, the loading is calculated including the masses of all fissile elements (equation 1). 
WSRC-STI-2006-00012, REV. 0

Table 25. Cumulative Plutonium Loading on MST

\begin{tabular}{|c|c|c|c|c|}
\hline Strike \# & \multicolumn{2}{|c|}{ Pu Loading (wt \%) } & \multicolumn{2}{|c|}{ Pu Loading (ug Pu/g MST) } \\
\hline PuTTa & Experiment A & Experiment B & Experiment A & Experiment B \\
\hline 1 & 0.189 & 0.189 & $1.92 \mathrm{E}+03$ & $1.93 \mathrm{E}+03$ \\
\hline 2 & 0.380 & 0.380 & $3.98 \mathrm{E}+03$ & $4.00 \mathrm{E}+03$ \\
\hline 3 & 0.563 & 0.559 & $6.04 \mathrm{E}+03$ & $6.08 \mathrm{E}+03$ \\
\hline 4 & 0.729 & 0.725 & $8.10 \mathrm{E}+03$ & $8.16 \mathrm{E}+03$ \\
\hline 5 & 0.887 & 0.881 & $1.02 \mathrm{E}+04$ & $1.02 \mathrm{E}+04$ \\
\hline $\begin{array}{l}\text { Solids (by } \\
\text { digestion) }\end{array}$ & 0.995 & 1.01 & $1.15 \mathrm{E}+04$ & $1.18 \mathrm{E}+04$ \\
\hline Control $24 \mathrm{~h}$ & 0.188 & 0.190 & $1.91 \mathrm{E}+03$ & $1.93 \mathrm{E}+03$ \\
\hline Control $120 \mathrm{~h}$ & 0.203 & 0.200 & $2.08 \mathrm{E}+03$ & $2.09 \mathrm{E}+03$ \\
\hline $\begin{array}{l}\text { Solids (by } \\
\text { digestion) }\end{array}$ & 0.196 & 0.177 & $2.01 \mathrm{E}+03$ & $1.84 \mathrm{E}+03$ \\
\hline ICPMS & Experiment A & Experiment B & Experiment A & Experiment B \\
\hline 1 & 0.192 & 0.193 & $1.95 \mathrm{E}+03$ & $1.97 \mathrm{E}+03$ \\
\hline 2 & 0.380 & 0.394 & $3.98 \mathrm{E}+03$ & $4.15 \mathrm{E}+03$ \\
\hline 3 & 0.553 & 0.570 & $5.94 \mathrm{E}+03$ & $6.21 \mathrm{E}+03$ \\
\hline 4 & 0.720 & 0.734 & $8.01 \mathrm{E}+03$ & $8.27 \mathrm{E}+03$ \\
\hline 5 & 0.877 & 0.889 & $1.01 \mathrm{E}+04$ & $1.03 \mathrm{E}+04$ \\
\hline $\begin{array}{l}\text { Solids (by } \\
\text { digestion) }\end{array}$ & 0.912 & 0.896 & $1.05 \mathrm{E}+04$ & $1.04 \mathrm{E}+04$ \\
\hline Control, $24 \mathrm{~h}$ & 0.182 & 0.190 & $1.85 \mathrm{E}+03$ & $1.93 \mathrm{E}+03$ \\
\hline Control, $120 \mathrm{~h}$ & 0.192 & 0.199 & $1.96 \mathrm{E}+03$ & $2.07 \mathrm{E}+03$ \\
\hline $\begin{array}{l}\text { Solids (by } \\
\text { digestion) }\end{array}$ & 0.206 & 0.209 & $2.11 \mathrm{E}+03$ & $2.17 \mathrm{E}+03$ \\
\hline
\end{tabular}

The PuTTa data uses ${ }^{239 / 240} \mathrm{Pu}$, while the ICPMS is the ${ }^{239} \mathrm{Pu}$ data only.

Averaging the results of both the PuTTa and ICPMS data for the duplicate experiments, we find the following cumulative plutonium loadings

$0.191 \pm 0.00185$ wt $\%$ or $1.94 \mathrm{E}+03 \pm 1.99 \mathrm{E}+01 \mu \mathrm{g}$ Pu/g MST after Strike\#1, $0.384 \pm 0.00698$ wt $\%$ or $4.02 \mathrm{E}+03 \pm 8.08 \mathrm{E}+01 \mu \mathrm{g} \mathrm{Pu} / \mathrm{g}$ MST after Strike\#2, $0.561 \pm 0.00700$ wt $\%$ or $6.07 \mathrm{E}+03 \pm 1.10 \mathrm{E}+02 \mu \mathrm{g} \mathrm{Pu} / \mathrm{g}$ MST after Strike\#3, $0.727 \pm 0.00599$ wt $\%$ or $8.14 \mathrm{E}+03 \pm 1.12 \mathrm{E}+02 \mu \mathrm{g} \mathrm{Pu} / \mathrm{g}$ MST after Strike\#4, and

$0.884 \pm 0.00539$ wt $\%$ or $1.02 \mathrm{E}+04 \pm 1.12 \mathrm{E}+02 \mu \mathrm{g} \mathrm{Pu} / \mathrm{g}$ MST after Strike\#5. 
Analysis of the recovered MST solids after Strike\#5 provided an average plutonium loading of $0.953 \pm 0.0575 \mathrm{wt} \%$ (or $1.10 \mathrm{E}+04 \pm 6.77 \mathrm{E}+02 \mu \mathrm{g}$ of plutonium per $\mathrm{g}$ of MST). The values obtained by difference of the solution compositions agree within uncertainty with the values from digestion of the final solids. Hence, recovery of the solids in each sequential experiment appears nearly complete.

If we average the results of both the PuTTa and ICPMS data for the duplicate controls, we find the following plutonium loadings

$0.187 \pm 0.00386$ wt $\%$ or $1.90 \mathrm{E}+03 \pm 3.98 \mathrm{E}+01 \mu \mathrm{g} \mathrm{Pu} / \mathrm{g}$ MST after 24 hours, and

$0.198 \pm 0.00482$ wt $\%$ or $2.05 \mathrm{E}+03 \pm 5.84 \mathrm{E}+01 \mu \mathrm{g}$ Pu/g MST after 120 hours.

Analysis of the recovered MST solids after 120 hours of contact provides an average plutonium loading of $0.197 \pm 0.0144 \mathrm{wt} \%$ (or $2.03 \mathrm{E}+03 \pm 1.44 \mathrm{E}+02 \mu \mathrm{g}$ of plutonium per $\mathrm{g}$ of MST). This result is an excellent match to the loading values derived from the supernate data.

Table 26 provides the measured step-wise loadings of plutonium onto MST for each test.

Table 26. Step-wise Plutonium Loading on MST

\begin{tabular}{|c|c|c|c|c|}
\hline Strike \# & \multicolumn{2}{|c|}{ Pu Loading (wt \%) } & \multicolumn{2}{|c|}{ Pu Loading (ug Pu/g MST) } \\
\hline PuTTa & Experiment A & Experiment B & Experiment A & Experiment B \\
\hline 1 & 0.189 & 0.189 & $1.92 \mathrm{E}+03$ & $1.93 \mathrm{E}+03$ \\
\hline 2 & 0.191 & 0.191 & $2.06 \mathrm{E}+03$ & $2.07 \mathrm{E}+03$ \\
\hline 3 & 0.183 & 0.179 & $2.06 \mathrm{E}+03$ & $2.08 \mathrm{E}+03$ \\
\hline 4 & 0.166 & 0.166 & $2.06 \mathrm{E}+03$ & $2.08 \mathrm{E}+03$ \\
\hline 5 & 0.158 & 0.156 & $2.10 \mathrm{E}+03$ & $2.04 \mathrm{E}+03$ \\
\hline Control $24 \mathrm{~h}$ & 0.188 & 0.190 & $1.91 \mathrm{E}+03$ & $1.93 \mathrm{E}+03$ \\
\hline Control $120 \mathrm{~h}$ & 0.0150 & 0.0100 & $1.70 \mathrm{E}+02$ & $1.60 \mathrm{E}+02$ \\
\hline ICPMS & Experiment A & Experiment B & Experiment A & Experiment B \\
\hline 1 & 0.192 & 0.193 & $1.95 \mathrm{E}+03$ & $1.97 \mathrm{E}+03$ \\
\hline 2 & 0.188 & 0.201 & $2.03 \mathrm{E}+03$ & $2.18 \mathrm{E}+03$ \\
\hline 3 & 0.173 & 0.176 & $1.96 \mathrm{E}+03$ & $2.06 \mathrm{E}+03$ \\
\hline 4 & 0.167 & 0.164 & $2.07 \mathrm{E}+03$ & $2.06 \mathrm{E}+03$ \\
\hline 5 & 0.157 & 0.155 & $2.09 \mathrm{E}+03$ & $2.03 \mathrm{E}+03$ \\
\hline Control, $24 \mathrm{~h}$ & 0.182 & 0.190 & $1.85 \mathrm{E}+03$ & $1.93 \mathrm{E}+03$ \\
\hline Control, $120 \mathrm{~h}$ & 0.0100 & 0.00900 & $1.10 \mathrm{E}+02$ & $1.40 \mathrm{E}+02$ \\
\hline
\end{tabular}


The PuTTa data uses ${ }^{239 / 240} \mathrm{Pu}$, while the ICPMS is the ${ }^{239} \mathrm{Pu}$ data only.

The most similar prior experiment is from work in $2005 .{ }^{11}$ The prior testing occurred at $25^{\circ} \mathrm{C}$ using the same simulant as used in this work (Table 5).

The previous testing used a lower MST (QAB-417) concentration equivalent to 5.88\% $(1 / 17$, or $0.0235 \mathrm{~g} / \mathrm{L})$ of that used in this work. The closest comparison of the two sets of work is for the Strike\#1 and the 24 hour Control data in this work with the 24 hour contact time in the previous study (Table 27). In comparison, the wt $\%$ and $\mu \mathrm{g} / \mathrm{g}$ MST plutonium loading detailed in this work were about $20 \%$ of those achieved in the previous data set.

Table 27. Mass Loading Comparisons on MST

\begin{tabular}{|l|c|c|}
\hline & wt \% Loading & $\mu \mathrm{g} / \mathrm{g}$ MST Loading \\
\hline This Work & $0.191 \pm 0.00185$ & $(0.194 \pm 0.00199) \mathrm{E}+04$ \\
\hline Previous Work & $1.02 \pm 0.0647$ & $(1.09 \pm 0.0633) \mathrm{E}+04$ \\
\hline
\end{tabular}

So, using 17 times the concentration of MST in this work only achieved a loading onefifth of that found in the previous work.

\subsubsection{Plutonium Mass Balance}

One check of internal data consistency is to determine the sum of plutonium sorbed based on the analytical results from the filtrate and compare with the amount of plutonium measured on the digested MST solids. Table 28 contains the data. For the plutonium in the supernate before MST addition, the value is the average of four samples (i.e., three from equilibration and one initial sample). For the plutonium on the digested MST, the amount of plutonium captured on all the MST is corrected for the recovered quantity of MST (80-90\% depending on which experiment). In Table 25, the \% Mass Balance term is calculated by dividing the sum of [plutonium measured on the MST and the plutonium left in each of the 5 bottles after the addition of MST] by the sum of [amount of plutonium present in each of the five strike bottles before the addition of MST]. Across all replicates and analyses the mass balance averaged $104 \pm 8.38 \%$ for plutonium. 
WSRC-STI-2006-00012, REV. 0

Table 28. ${ }^{239 / 40}$ Plutonium Mass Balance

\begin{tabular}{|c|c|c|c|c|}
\hline & $\begin{array}{c}\text { Pu in } \\
\text { Filtrate } \\
\text { Before MST } \\
(\mu \mathbf{g})\end{array}$ & $\begin{array}{c}\text { Pu in } \\
\text { Filtrate after } \\
\mathbf{M S T} \\
(\mu \mathbf{g})\end{array}$ & $\begin{array}{c}\text { Pu on MST } \\
\text { Solids } \\
(\mu \mathbf{g})\end{array}$ & $\begin{array}{c}\text { \% Mass } \\
\text { Balance } \\
(\boldsymbol{\%})\end{array}$ \\
\hline PuTTA & & & & \\
\hline A & $4.20 \mathrm{E}+03$ & $1.26 \mathrm{E}+02$ & $4.58 \mathrm{E}+03$ & 112 \\
\hline B & $4.20 \mathrm{E}+03$ & $1.02 \mathrm{E}+02$ & $4.71 \mathrm{E}+03$ & 115 \\
\hline Control A & $8.40 \mathrm{E}+02$ & $9.16 \mathrm{E}+00$ & $8.03 \mathrm{E}+02$ & 96.7 \\
\hline Control B & $8.40 \mathrm{E}+02$ & $5.36 \mathrm{E}+00$ & $7.37 \mathrm{E}+02$ & 88.5 \\
\hline & & & & \\
\hline ICP-MS & & & & 104 \\
\hline A & $4.21 \mathrm{E}+03$ & $1.80 \mathrm{E}+02$ & $4.20 \mathrm{E}+03$ & 102 \\
\hline B & $4.21 \mathrm{E}+03$ & $1.28 \mathrm{E}+03$ & $4.17 \mathrm{E}+03$ & 107 \\
\hline Control A & $8.41 \mathrm{E}+02$ & $5.70 \mathrm{E}+01$ & $8.42 \mathrm{E}+02$ & 107 \\
\hline Control B & $8.41 \mathrm{E}+02$ & $1.44 \mathrm{E}+01$ & $8.69 \mathrm{E}+02$ & 105 \\
\hline
\end{tabular}

\subsubsection{MST Multi-Strike Removal of Uranium from Solution}

Personnel determined ${ }^{235 / 8} \mathrm{U}$ in solution was monitored by ICPMS (Table 29). Figure 12 provides a graphical representation of the data.

Uranium concentrations in the solution without MST (Blank) remained stable throughout the duration of the experiment, indicating chemical stability and absence of complicating factors such as precipitation or deposition on equipment. The control experiments with a single addition of MST show the intuitive trend expected from a single, long term strike. Both controls show an expected initial DF ( 1.25) at 24 hours, followed by an improved DF after 120 hours.

The Strike\#1 results for Experiments A and B and the 24 hour results for the controls (i.e., Control A and Control B) give essentially the same result. This is expected as all four of these bottles experienced the same conditions at that time; a single addition of MST at $0.4 \mathrm{~g} / \mathrm{L}$ removed by filtration after 24 hours.

The experimental results for the five sequential experiments show the same counterintuitive trend found with the plutonium data. Instead of seeing the ability of MST to sorb uranium decrease on sequential uses, the MST shows improved sorption capability over the entire experiment. The data shows that when reusing the MST a second (Strike\#2) and a third time (Strike\#3), the MST removes more uranium from solution 
than it did in the previous strike. From the third to fifth use, the MST sorbs about the same amount of uranium from solution.

Table 29. MST Sorption of Uranium from Solution

\begin{tabular}{|c|c|c|c|}
\hline & & \multicolumn{2}{|c|}{ ICPMS } \\
\hline Control & $\begin{array}{c}\text { Time } \\
(\mathbf{h})\end{array}$ & $\begin{array}{c}\text { Supernate } \\
{ }^{335 / 8} \mathbf{U}(\mu \mathbf{g} / \mathbf{L})\end{array}$ & DF \\
\hline A & 24 & $2.14 \mathrm{E}+04( \pm 4.27 \mathrm{E}+03)$ & $1.24 \pm 0.248$ \\
\hline B & 24 & $2.11 \mathrm{E}+04( \pm 4.22 \mathrm{E}+03)$ & $1.26 \pm 0.252$ \\
\hline A & 120 & $1.88 \mathrm{E}+04( \pm 3.76 \mathrm{E}+03)$ & $1.41 \pm 0.282$ \\
\hline B & 120 & $1.16 \mathrm{E}+04( \pm 2.32 \mathrm{E}+03)$ & $2.29 \pm 0.458$ \\
\hline Blank & $\begin{array}{c}\text { Time } \\
(\mathbf{h})\end{array}$ & & \\
\hline 0 & 0 & $2.66 \mathrm{E}+04( \pm 5.32 \mathrm{E}+03)$ & NA \\
\hline 1 & 24 & $2.39 \mathrm{E}+04( \pm 4.78 \mathrm{E}+03)$ & NA \\
\hline 2 & 96 & $2.47 \mathrm{E}+04( \pm 4.94 \mathrm{E}+03)$ & NA \\
\hline 3 & 120 & $2.53 \mathrm{E}+04( \pm 5.06 \mathrm{E}+03)$ & NA \\
\hline Experiment & $\begin{array}{c}\text { Strike } \\
\#\end{array}$ & $\begin{array}{c}\text { Supernate } \\
\text { 235/8 }(\mu \mathbf{g} / \mathbf{L})\end{array}$ & DF \\
\hline A & 1 & $2.07 \mathrm{E}+04( \pm 4.14 \mathrm{E}+03)$ & $1.28 \pm 0.256$ \\
\hline B & 1 & $1.94 \mathrm{E}+04( \pm 3.88 \mathrm{E}+03)$ & $1.37 \pm 0.274$ \\
\hline A & 2 & $1.61 \mathrm{E}+04( \pm 3.21 \mathrm{E}+03)$ & $1.66 \pm 0.332$ \\
\hline B & 2 & $1.54 \mathrm{E}+04( \pm 3.07 \mathrm{E}+03)$ & $1.73 \pm 0.346$ \\
\hline A & 3 & $1.70 \mathrm{E}+04( \pm 3.40 \mathrm{E}+03)$ & $1.56 \pm 0.312$ \\
\hline B & 3 & $1.30 \mathrm{E}+04( \pm 2.61 \mathrm{E}+03)$ & $2.04 \pm 0.408$ \\
\hline A & 4 & $1.27 \mathrm{E}+04( \pm 2.54 \mathrm{E}+03)$ & $2.09 \pm 0.418$ \\
\hline B & 4 & $1.27 \mathrm{E}+04( \pm 2.54 \mathrm{E}+03)$ & $2.09 \pm 0.418$ \\
\hline A & 5 & $1.35 \mathrm{E}+04( \pm 2.70 \mathrm{E}+03)$ & $1.97 \pm 0.394$ \\
\hline B & 5 & $1.36 \mathrm{E}+04( \pm 2.71 \mathrm{E}+03)$ & $1.96 \pm 0.392$ \\
\hline & & &
\end{tabular}


Figure 12. ${ }^{235 / 38}$ Uranium in Solution

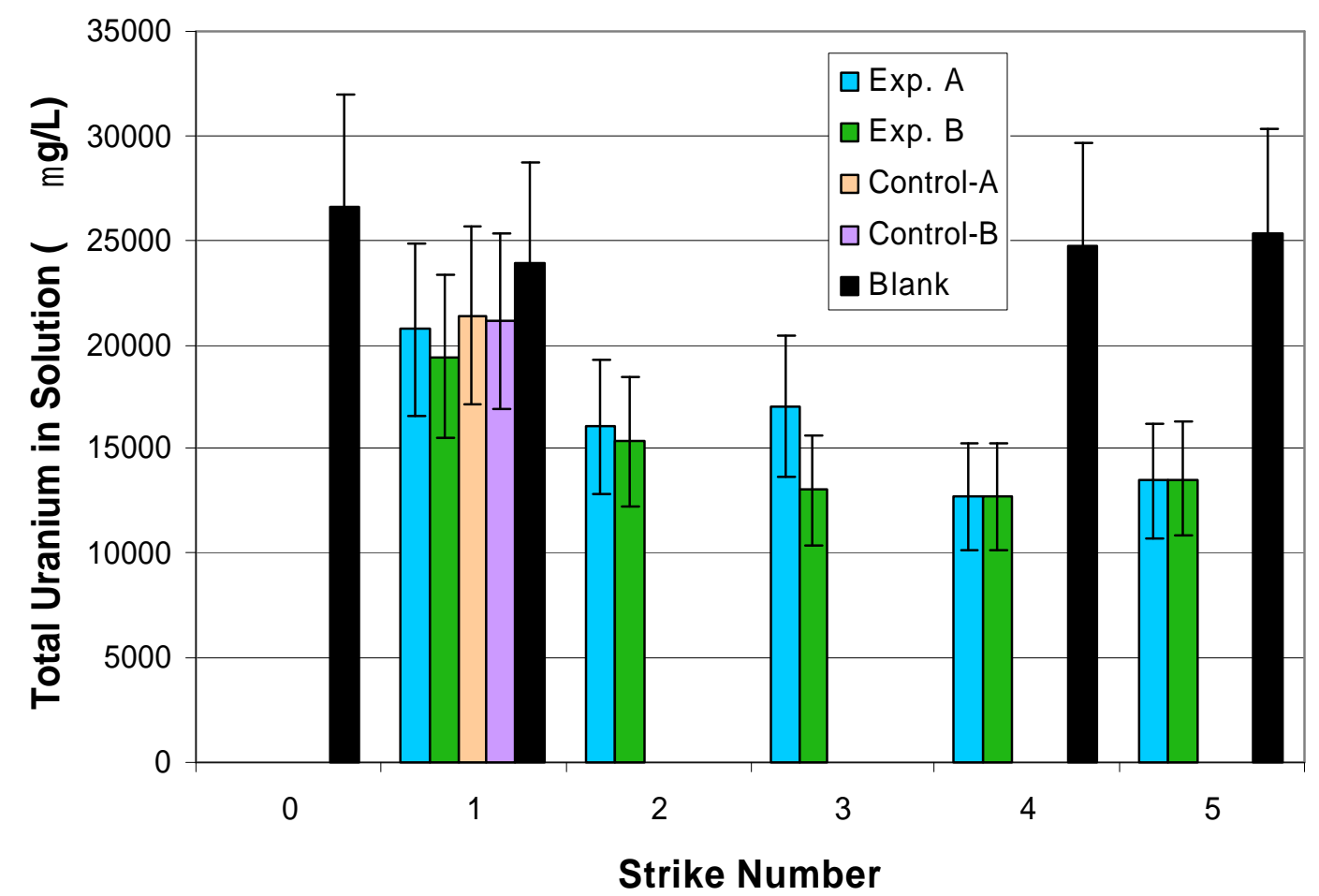

\subsubsection{Cumulative Loading of Uranium onto MST}

Table 30 provides the measured loadings of uranium onto MST for each test. Except for the $\mu \mathrm{g} / \mathrm{g}$ results, the values in the table are calculated based on the quantity of uranium removed from solution and the quantity of MST added to each test bottle. The $\mu \mathrm{g} / \mathrm{g}$ results are calculated from analyses of the digested MST solids recovered at the end of the experiments. Loading values are provided on wt $\%$ and $\mu \mathrm{g}$ U/g MST bases. The wt $\%$ basis is calculated using the analogous expression for equation 1 . 
Table 30. Cumulative Uranium Loading on MST

\begin{tabular}{|c|c|c|c|c|}
\hline Strike \# & \multicolumn{2}{|c|}{ U Loading (wt \%) } & \multicolumn{2}{|c|}{ U Loading ( $\mu \mathrm{g}$ U/g MST) } \\
\hline & Experiment A & Experiment B & Experiment A & Experiment B \\
\hline 1 & 1.44 & 1.76 & $1.47 \mathrm{E}+04$ & $1.79 \mathrm{E}+04$ \\
\hline 2 & 3.92 & 4.37 & $4.10 \mathrm{E}+04$ & $4.60 \mathrm{E}+04$ \\
\hline 3 & 6.05 & 7.33 & $6.50 \mathrm{E}+04$ & $7.99 \mathrm{E}+04$ \\
\hline 4 & 8.97 & 10.2 & $9.97 \mathrm{E}+04$ & $1.15 \mathrm{E}+05$ \\
\hline 5 & 11.5 & 12.7 & $1.33 \mathrm{E}+05$ & $1.47 \mathrm{E}+05$ \\
\hline $\begin{array}{l}\text { Solids (by } \\
\text { digestion) }\end{array}$ & 11.7 & 12.8 & $1.35 \mathrm{E}+05$ & $1.49 \mathrm{E}+05$ \\
\hline Control, $24 \mathrm{~h}$ & 1.29 & 1.35 & $1.31 \mathrm{E}+04$ & $1.37 \mathrm{E}+04$ \\
\hline Control, $120 \mathrm{~h}$ & 1.90 & 3.60 & $1.95 \mathrm{E}+04$ & $3.75 \mathrm{E}+04$ \\
\hline $\begin{array}{l}\text { Solids-(by } \\
\text { digestion) }\end{array}$ & 1.81 & 3.67 & $1.85 \mathrm{E}+04$ & $3.82 \mathrm{E}+04$ \\
\hline
\end{tabular}

If we average the duplicate experiments, we find the following uranium loadings

$1.60 \pm 0.221 \mathrm{wt} \%$ or $1.63 \mathrm{E}+04 \pm 2.29 \mathrm{E}+03 \mu \mathrm{g} \mathrm{U} / \mathrm{g}$ MST after Strike\#1,

$4.15 \pm 0.319$ wt \% or $4.35 \mathrm{E}+04 \pm 3.49 \mathrm{E}+03 \mu \mathrm{g} \mathrm{U} / \mathrm{g}$ MST after Strike\#2,

$6.70 \pm 0.905 \mathrm{wt} \%$ or $7.24 \mathrm{E}+04 \pm 1.05 \mathrm{E}+04 \mu \mathrm{g} \mathrm{U} / \mathrm{g}$ MST after Strike\#3,

$9.57 \pm 0.847$ wt \% or $1.07 \mathrm{E}+05 \pm 1.05 \mathrm{E}+04 \mu \mathrm{g}$ U/g MST after Strike\#4, and

$12.1 \pm 0.786 \mathrm{wt} \%$ or $1.40 \mathrm{E}+05 \pm 1.04 \mathrm{E}+04 \mu \mathrm{g} \mathrm{U} / \mathrm{g}$ MST after Strike\#5.

The analysis of the recovered MST solids after Strike\#5 provided an average uranium loading of $12.3 \pm 0.760 \mathrm{wt} \%$ (or $1.42 \mathrm{E}+05 \pm 1.00 \mathrm{E}+04 \mu \mathrm{g}$ of uranium per g of MST). This is an excellent match with the wt \% loading results from the supernate data after the fifth strike.

If we average the results of both the duplicate controls, we find the following uranium loadings

$1.32 \pm 0.0420 \mathrm{wt} \%$ or $1.34 \mathrm{E}+04 \pm 4.33 \mathrm{E}+02 \mu \mathrm{g} \mathrm{U} / \mathrm{g}$ MST after 24 hours, and

$2.75 \pm 1.20 \mathrm{wt} \%$ or $2.85 \mathrm{E}+04 \pm 1.28 \mathrm{E}+04 \mu \mathrm{g} \mathrm{U} / \mathrm{g}$ MST after 120 hours.

The analysis of the recovered MST solids after 120 hours of contact provided an average uranium loading of $2.74 \pm 1.31 \mathrm{wt} \%$ (or $2.84 \mathrm{E}+04 \pm 1.39 \mathrm{E}+04 \mu \mathrm{g}$ of uranium per g of 
MST). The wt \% loading values agree quite well with those from the final supernate sample.

Table 31 provides the measured step-wise loadings of uranium onto MST for each test.

Table 31. Step-wise Uranium Loading on MST

\begin{tabular}{|c|c|c|c|c|}
\hline Strike \# & \multicolumn{2}{|c|}{ U Loading (wt \%) } & \multicolumn{2}{|c|}{ U Loading ( $\mu \mathrm{g}$ U/g MST) } \\
\hline & Experiment A & Experiment B & Experiment A & Experiment B \\
\hline 1 & 1.44 & 1.76 & $1.47 \mathrm{E}+04$ & $1.79 \mathrm{E}+04$ \\
\hline 2 & 2.48 & 2.61 & $2.63 \mathrm{E}+04$ & $2.81 \mathrm{E}+04$ \\
\hline 3 & 2.13 & 2.96 & $2.40 \mathrm{E}+04$ & $3.39 \mathrm{E}+04$ \\
\hline 4 & 2.92 & 2.87 & $3.47 \mathrm{E}+04$ & $3.51 \mathrm{E}+04$ \\
\hline 5 & 2.53 & 2.50 & $3.33 \mathrm{E}+04$ & $3.20 \mathrm{E}+04$ \\
\hline Control, $24 \mathrm{~h}$ & 1.29 & 1.35 & $1.31 \mathrm{E}+04$ & $1.37 \mathrm{E}+04$ \\
\hline Control, $120 \mathrm{~h}$ & 0.610 & 2.25 & $6.40 \mathrm{E}+03$ & $2.38 \mathrm{E}+04$ \\
\hline
\end{tabular}

The most similar comparison point is from work completed in $2005 .^{7}$ The previous testing occurred at $25^{\circ} \mathrm{C}$ using exactly the same simulant as used in this work. The prior MST study used the equivalent of $5.88 \%(1 / 17$, or $0.0235 \mathrm{~g} / \mathrm{L})$ of that used in this work, but the same material (Optima batch\# 00-QAB-417). The closest comparison of the two data sets is for the Strike\#1 experimental and 24 hour Control data in this work and the 24 hour contact time in the previous work (Table 32). In this comparison, the wt $\%$ and $\mu \mathrm{g} / \mathrm{g}$ MST uranium loading detailed in this work was about one-third of what was achieved in the previous data set.

Table 32. Uranium Mass Loading Comparisons on MST

\begin{tabular}{|l|c|c|}
\hline & wt \% Loading & $\mu \mathrm{g} / \mathrm{g}$ MST Loading \\
\hline This Work & $1.60 \pm 0.221$ & $(1.63 \pm 0.229) \mathrm{E}+04$ \\
\hline Previous Work & $4.74 \pm 1.17$ & $(5.06 \pm 1.31) \mathrm{E}+04$ \\
\hline
\end{tabular}

So, using 17 times the concentration of MST in this work only achieved a loading onethird as much of that found in the previous work.

\subsubsection{Uranium Mass Balance}

One check of internal data consistency is to determine the sum of uranium sorbed based on the analytical results from the filtrate and compare with the amount of uranium 
measured on the digested MST solids. Table 33 contains the data. For the uranium in the supernate before MST addition, the value is the average of four samples (i.e., three from equilibration and one initial sample). For the uranium on the digested MST, the amount of uranium captured on all the MST is corrected for the recovered quantity of MST (80-90\% depending on which experiment). In Table 29, the \% Mass Balance term is calculated by dividing the sum of [uranium measured on the MST and the uranium left in each of the 5 bottles after the addition of MST] by the sum of [amount of uranium present in each of the five strike bottles before the addition of MST]. Across all replicates and analyses the mass balance averaged $100 \pm 1.13 \%$ for uranium.

Table 33. Uranium Mass Balance

\begin{tabular}{|c|c|c|c|c|}
\hline & $\begin{array}{c}\text { U in Filtrate } \\
\text { Before MST } \\
(\mu \mathbf{g})\end{array}$ & $\begin{array}{c}\text { U in Filtrate } \\
\text { after MST } \\
(\mu \mathbf{g})\end{array}$ & $\begin{array}{c}\text { U on MST } \\
\text { Solids } \\
(\mu \mathbf{g})\end{array}$ & $\begin{array}{c}\text { \% Mass } \\
\text { Balance } \\
(\boldsymbol{\%})\end{array}$ \\
\hline A & $1.33 \mathrm{E}+05$ & $8.00 \mathrm{E}+04$ & $5.39 \mathrm{E}+04$ & 101 \\
\hline B & $1.33 \mathrm{E}+05$ & $7.41 \mathrm{E}+04$ & $5.96 \mathrm{E}+04$ & 101 \\
\hline Control A & $2.66 \mathrm{E}+04$ & $1.88 \mathrm{E}+04$ & $7.40 \mathrm{E}+03$ & 98.6 \\
\hline Control B & $2.66 \mathrm{E}+04$ & $1.16 \mathrm{E}+04$ & $1.53 \mathrm{E}+04$ & 101 \\
\hline
\end{tabular}

\subsubsection{MST Multi-Strike Removal of Neptunium from Solution}

Researchers determined ${ }^{237} \mathrm{~Np}$ in solution by ICPMS (Table 34). Figure 13 depicts the data for the experiments.

Neptunium concentrations in the solution without MST indicate chemical stability and absence of complicating factors such as precipitation or deposition on equipment. The control experiments with a single addition of MST show the intuitive trend expected from a single, long term strike. Both controls show an initial DF ( 3) at 24 hours followed by an improved DF after 120 hours. We note that we see the same trend for plutonium, uranium, and neptunium when comparing the two controls at 120 hours. Note that the Control A indicates a higher analyte concentration in solution. This observation is common to the other (plutonium, uranium) actinides as well. The variance is not due to an analytical method issue. Rather, the variance must reflect an experimental deviation. In the measured variance results in values for the 120 hour control samples. The ratio of the Control A to Control B results is not a constant for the three radionuclides, indicating the problem is not related to improper sample dilution for one of the 120 hour Control samples.

The Strike\#1 results for Experiments A and B and the 24 hour results for Control A and Control B give essentially the same result. This observation is expected as all four of these bottles experienced the same conditions; a single strike of MST at $0.4 \mathrm{~g} / \mathrm{L}$ followed by filtration after 24 hours. 
Again, the experimental results show a trend that is counter-intuitive. Instead of seeing the ability of MST to sorb neptunium decrease for multiple uses, the MST shows improved sorption capability over the entire experiment. The data shows that when reusing the MST a second (Strike\#2) and a third time (Strike\#3), the MST removes more neptunium from solution than it did in the previous strike. From the third to fifth use, the MST sorbs about the same amount of neptunium from solution.

Table 34. MST Sorption of ${ }^{237} \mathrm{~Np}$ from Solution

\begin{tabular}{|c|c|c|c|}
\hline & & \multicolumn{2}{|c|}{ ICPMS } \\
\hline Control & $\begin{array}{l}\text { Time } \\
\text { (h) }\end{array}$ & $\begin{array}{l}\text { Supernate } \\
{ }^{237} \mathrm{~Np}(\mu \mathrm{g} / \mathrm{L})\end{array}$ & DF \\
\hline $\mathrm{A}$ & 24 & $1.57 \mathrm{E}+02( \pm 3.14 \mathrm{E}+01)$ & $3.08 \pm 0.616$ \\
\hline $\mathrm{B}$ & 24 & $1.80 \mathrm{E}+02( \pm 3.60 \mathrm{E}+01)$ & $2.69 \pm 0.538$ \\
\hline A & 120 & $8.30 \mathrm{E}+01( \pm 1.66 \mathrm{E}+01)$ & $5.83 \pm 1.17$ \\
\hline $\mathrm{B}$ & 120 & $<2.50 \mathrm{E}+01(\mathrm{NA})$ & $>19.4$ \\
\hline Blank & $\begin{array}{c}\text { Time } \\
\text { (h) }\end{array}$ & $\begin{array}{c}\text { Supernate } \\
{ }^{237} \mathrm{~Np}(\mu \mathrm{g} / \mathrm{L})\end{array}$ & DF \\
\hline 0 & 0 & $4.84 \mathrm{E}+02( \pm 9.68 \mathrm{E}+01)$ & NA \\
\hline 1 & 24 & $4.34 \mathrm{E}+02( \pm 8.68 \mathrm{E}+01)$ & NA \\
\hline 2 & 96 & $4.30 \mathrm{E}+02( \pm 8.60 \mathrm{E}+01)$ & NA \\
\hline 3 & 120 & $4.34 \mathrm{E}+02( \pm 8.68 \mathrm{E}+01)$ & NA \\
\hline Experiment & $\begin{array}{c}\text { Strike } \\
\#\end{array}$ & $\begin{array}{c}\text { Supernate } \\
{ }^{237} \mathrm{~Np}(\mu \mathrm{g} / \mathrm{L})\end{array}$ & DF \\
\hline A & 1 & $1.73 \mathrm{E}+02( \pm 3.46 \mathrm{E}+01)$ & $2.80 \pm 0.560$ \\
\hline $\mathrm{B}$ & 1 & $1.38 \mathrm{E}+02( \pm 2.77 \mathrm{E}+01)$ & $3.50 \pm 0.700$ \\
\hline A & 2 & $1.12 \mathrm{E}+02( \pm 2.23 \mathrm{E}+01)$ & $4.34 \pm 0.868$ \\
\hline $\mathrm{B}$ & 2 & $1.22 \mathrm{E}+02( \pm 2.43 \mathrm{E}+01)$ & $3.98 \pm 0.796$ \\
\hline $\mathrm{A}$ & 3 & $8.35 \mathrm{E}+01( \pm 1.67 \mathrm{E}+01)$ & $5.80 \pm 1.16$ \\
\hline $\mathrm{B}$ & 3 & $5.84 \mathrm{E}+01( \pm 1.17 \mathrm{E}+01)$ & $8.29 \pm 1.66$ \\
\hline A & 4 & $5.72 \mathrm{E}+01( \pm 1.14 \mathrm{E}+01)$ & $8.47 \pm 1.69$ \\
\hline $\mathrm{B}$ & 4 & $5.42 \mathrm{E}+01( \pm 1.08 \mathrm{E}+01)$ & $8.93 \pm 1.79$ \\
\hline A & 5 & $5.44 \mathrm{E}+01( \pm 1.09 \mathrm{E}+01)$ & $8.90 \pm 1.78$ \\
\hline B & 5 & $5.48 \mathrm{E}+01( \pm 1.10 \mathrm{E}+01)$ & $8.84 \pm 1.77$ \\
\hline
\end{tabular}




\section{Figure 13. ${ }^{237}$ Neptunium in Solution}

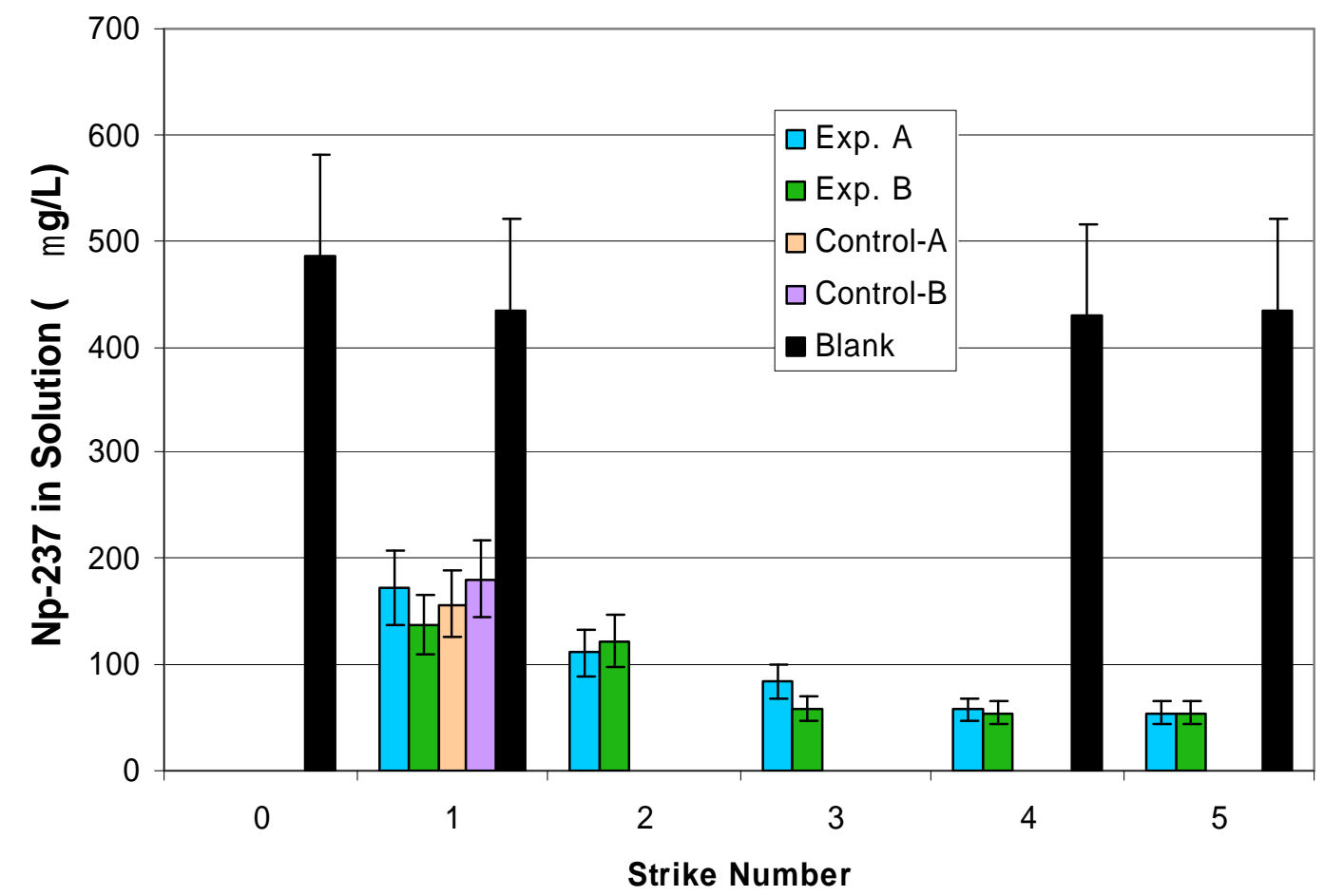

\subsubsection{Cumulative Loading of Neptunium onto MST}

Table 35 provides the measured cumulative loadings of neptunium onto MST for each test. Except for the $\mu \mathrm{g} / \mathrm{g}$ results, the values in the table are calculated based on the quantity of neptunium removed from solution and the quantity of MST added to each test bottle. The $\mu \mathrm{g} / \mathrm{g}$ results are calculated from analyses of the digested MST solids recovered at the end of the experiments. Loading values are provided on wt $\%$ and $\mu \mathrm{g} \mathrm{Np/g} \mathrm{MST} \mathrm{bases} \mathrm{with} \mathrm{the} \mathrm{former} \mathrm{calculated} \mathrm{using} \mathrm{a} \mathrm{formula} \mathrm{analogous} \mathrm{to} \mathrm{equation} 1$. 
Table 35. Cumulative ${ }^{237} \mathrm{~Np}$ Loading on MST

\begin{tabular}{|c|c|c|c|c|}
\hline Strike \# & \multicolumn{2}{|c|}{${ }^{237} \mathrm{~Np}$ Loading (wt \%) } & \multicolumn{2}{|c|}{${ }^{237} \mathrm{~Np}$ Loading $(\mu \mathrm{g}$ Np/g MST $)$} \\
\hline & Experiment A & Experiment B & Experiment A & Experiment B \\
\hline 1 & 0.0765 & 0.0847 & $7.78 \mathrm{E}+02$ & $8.65 \mathrm{E}+02$ \\
\hline 2 & 0.163 & 0.168 & $1.71 \mathrm{E}+03$ & $1.77 \mathrm{E}+03$ \\
\hline 3 & 0.253 & 0.260 & $2.71 \mathrm{E}+03$ & $2.84 \mathrm{E}+03$ \\
\hline 4 & 0.340 & 0.347 & $3.78 \mathrm{E}+03$ & $3.91 \mathrm{E}+03$ \\
\hline 5 & 0.423 & 0.429 & $4.85 \mathrm{E}+03$ & $4.98 \mathrm{E}+03$ \\
\hline $\begin{array}{l}\text { Solids (by } \\
\text { digestion) }\end{array}$ & 0.415 & 0.419 & $4.77 \mathrm{E}+03$ & $4.88 \mathrm{E}+03$ \\
\hline Control, $24 \mathrm{~h}$ & 0.0805 & 0.0748 & $8.18 \mathrm{E}+02$ & $7.61 \mathrm{E}+02$ \\
\hline Control, $120 \mathrm{~h}$ & 0.117 & 0.112 & $1.20 \mathrm{E}+03$ & $1.16 \mathrm{E}+03$ \\
\hline $\begin{array}{l}\text { Solids (by } \\
\text { digestion) }\end{array}$ & 0.107 & 0.110 & $1.09 \mathrm{E}+03$ & $1.14 \mathrm{E}+03$ \\
\hline
\end{tabular}

If we average the duplicate experiments, we find the following neptunium loadings

$0.0806 \pm 0.00582 \mathrm{wt} \%$ or $8.21 \mathrm{E}+02 \pm 6.12 \mathrm{E}+01 \mu \mathrm{g} \mathrm{Np} / \mathrm{g}$ MST after Strike \#1, $0.166 \pm 0.00355 \mathrm{wt} \%$ or $1.74 \mathrm{E}+03 \pm 4.33 \mathrm{E}+01 \mu \mathrm{g} \mathrm{Np} / \mathrm{g}$ MST after Strike\#2, $0.256 \pm 0.00555 \mathrm{wt} \%$ or $2.77 \mathrm{E}+03 \pm 8.77 \mathrm{E}+01 \mu \mathrm{g}$ Np/g MST after Strike\#3, $0.344 \pm 0.00500 \mathrm{wt} \%$ or $3.85 \mathrm{E}+03 \pm 9.30 \mathrm{E}+01 \mu \mathrm{g} \mathrm{Np} / \mathrm{g}$ MST after Strike\#4, and

$0.426 \pm 0.00406 \mathrm{wt} \%$ or $4.92 \mathrm{E}+03 \pm 9.23 \mathrm{E}+01 \mu \mathrm{g} \mathrm{Np/g} \mathrm{MST} \mathrm{after} \mathrm{Strike \# 5.}$

The analysis of the recovered MST solids after Strike\#5 provided an average neptunium loading of $0.417 \pm 0.00279 \mathrm{wt} \%$ (or $4.82 \mathrm{E}+03 \pm 7.42 \mathrm{E}+01 \mu \mathrm{g}$ of neptunium per $\mathrm{g}$ of MST). This result once again shows an excellent match between the solids and final supernate derived values.

If we average the results of both the duplicate controls, we find the following neptunium loadings

$0.0777 \pm 0.00404 \mathrm{wt} \%$ or $7.89 \mathrm{E}+02 \pm 4.07 \mathrm{E}+01 \mu \mathrm{g} \mathrm{U} / \mathrm{g}$ MST after 24 hours, and

$0.114 \pm 0.00374 \mathrm{wt} \%$ or $1.18 \mathrm{E}+03 \pm 2.39 \mathrm{E}+01 \mu \mathrm{g} \mathrm{U} / \mathrm{g}$ MST after 120 hours. 
The analysis of the recovered MST solids after 120 hours of contact provided an average neptunium loading of $0.108 \pm 0.00171$ wt $\%$ (or $1.12 \mathrm{E}+03 \pm 3.28 \mathrm{E}+01 \mu \mathrm{g}$ of neptunium per $g$ of MST). As with the experimental data, the control data shows a good match between the solids and final supernate data.

Table 36 provides the measured step-wise loadings of neptunium onto MST for each test.

Table 36. Step-wise ${ }^{237} \mathrm{~Np}$ Loading on MST

\begin{tabular}{|c|c|c|c|c|}
\hline Strike \# & ${ }^{237}$ Np Loading (wt \%) & ${ }^{237}$ Np Loading $(\mu \mathrm{g}$ Np/g MST) \\
\hline & Experiment A & Experiment B & Experiment A & Experiment B \\
\hline 1 & 0.0765 & 0.0847 & $7.78 \mathrm{E}+02$ & $8.65 \mathrm{E}+02$ \\
\hline 2 & 0.0865 & 0.0833 & $9.32 \mathrm{E}+02$ & $9.05 \mathrm{E}+02$ \\
\hline 3 & 0.0900 & 0.0920 & $1.00 \mathrm{E}+03$ & $1.07 \mathrm{E}+03$ \\
\hline 4 & 0.0870 & 0.0870 & $1.16 \mathrm{E}+03$ & $1.07 \mathrm{E}+03$ \\
\hline 5 & 0.0830 & 0.0802 & $1.07 \mathrm{E}+03$ & $1.07 \mathrm{E}+03$ \\
\hline \multicolumn{5}{|l|}{} \\
\hline Control, 24 h & 0.0805 & 0.0748 & $8.18 \mathrm{E}+02$ & $7.61 \mathrm{E}+02$ \\
\hline Control, 120 h & 0.0365 & 0.0372 & $3.82 \mathrm{E}+02$ & $3.99 \mathrm{E}+02$ \\
\hline
\end{tabular}

The most similar prior experiment is from work done in $2005 .{ }^{11}$ The previous measurements occurred at $25^{\circ} \mathrm{C}$ using exactly the same simulant as used in this work. The earlier study added MST at the equivalent of $5.88 \%(1 / 17$, or $0.0235 \mathrm{~g} / \mathrm{L})$ of that used in this work, but the same material (QAB-417). The closest comparison of the two data sets is for the Strike\#1 data in this work and the 24 hour time in the previous work. In this comparison, the wt $\%$ and $\mu \mathrm{g} / \mathrm{g}$ MST neptunium loading detailed in this work was about one-third of what was achieved in the previous data set.

Table 37. ${ }^{237} \mathrm{~Np}$ Mass Loading Comparisons on MST

\begin{tabular}{|l|c|c|}
\hline & Wt \% Loading & $\mu$ g/g MST Loading \\
\hline This Work & $0.0806 \pm 0.00582$ & $(0.821 \pm 0.0612) \mathrm{E}+03$ \\
\hline Previous Work & $0.231 \pm 0.0101$ & $(2.46 \pm 0.130) \mathrm{E}+03$ \\
\hline
\end{tabular}

So, using 17 times the concentration of MST in this work only achieved a loading onethird as much of that found in the previous work. 


\subsubsection{Neptunium Mass Balance}

One check of internal data consistency is to determine the sum of neptunium sorbed based on the analytical results from the filtrate and compare with the amount of neptunium measured on the digested MST solids. Table 38 contains the data. For the neptunium in the supernate before MST addition, the value is the average of four samples (i.e., three from equilibration and one initial sample). For the neptunium on the digested MST, the amount of neptunium captured on all the MST is corrected for the recovered quantity of MST (80-90\% depending on which experiment). In Table 39, the \% Mass Balance term is calculated by dividing the sum of [neptunium measured on the MST and the neptunium left in each of the 5 bottles after the addition of MST] by the sum of [amount of neptunium present in each of the five strike bottles before the addition of MST]. Across all replicates (except for the less-than value) the mass balance averaged $102 \pm 5.55 \%$ for neptunium.

Table 38. ${ }^{237} \mathrm{~Np}$ Mass Balance

\begin{tabular}{|c|c|c|c|c|}
\hline & $\begin{array}{c}{ }^{237} \mathbf{N p} \text { in } \\
\text { Filtrate } \\
\text { Before MST } \\
(\mu \mathbf{g})\end{array}$ & $\begin{array}{c}{ }^{237} \mathbf{N p} \text { in } \\
\text { Filtrate after } \\
\mathbf{M S T} \\
(\boldsymbol{\mu g})\end{array}$ & $\begin{array}{c}{ }^{237} \mathbf{N p} \text { on } \\
\mathbf{M S T} \text { Solids } \\
(\mu \mathbf{g})\end{array}$ & $\begin{array}{c}\text { \% Mass } \\
\text { Balance } \\
(\boldsymbol{\%})\end{array}$ \\
\hline A & $2.42 \mathrm{E}+03$ & $4.80 \mathrm{E}+02$ & $1.91 \mathrm{E}+03$ & 98.6 \\
\hline B & $2.42 \mathrm{E}+03$ & $4.27 \mathrm{E}+02$ & $1.95 \mathrm{E}+03$ & 98.2 \\
\hline Control A & $4.84 \mathrm{E}+02$ & $8.30 \mathrm{E}+01$ & $4.38 \mathrm{E}+02$ & 108 \\
\hline Control B & $4.84 \mathrm{E}+02$ & $>2.50 \mathrm{E}+01$ & $4.57 \mathrm{E}+02$ & $<99.4$ \\
\hline
\end{tabular}

\subsubsection{MST Multi-Strike Removal of Strontium from Solution}

Analysts determined the ${ }^{85} \mathrm{Sr}$ in solution by Gamma Counting (Table 39). Figure 14 shows the data.

Strontium concentrations in the solution without MST remained stable throughout the duration of the experiment, indicating chemically stability and absence of complicating factors such as precipitation or deposition on equipment. The control experiments with a single addition of MST show the intuitive trend expected from a single, long term strike. Both controls show an expected initial DF ( 190) at 24 hours, followed by an improved DF ( 300) after 120 hours.

Strike\#1 results for Experiment B and the 24 hour results for the Control A and Control B give essentially the same result as expected since all three of these bottles experienced the same conditions; a single strike of MST at $0.4 \mathrm{~g} / \mathrm{L}$ followed by filtration after 24 . 
Unlike the results for the actinides, the strontium experimental results show the intuitive trend. We see the ability of MST to sorb strontium decreases with increasing number of uses. The data shows that when reusing the MST, the MST removes less strontium from solution in each successive strike.

Table 39. MST Sorption of ${ }^{85} \mathrm{Sr}$ from Solution

\begin{tabular}{|c|c|c|c|}
\hline & & \multicolumn{2}{|c|}{ Gamma counting } \\
\hline Control & $\begin{array}{c}\text { Time } \\
(\mathbf{h})\end{array}$ & $\begin{array}{c}\text { Supernate } \\
\mathbf{8 5} \mathbf{S r}(\mathbf{d p m} / \mathbf{m L})\end{array}$ & DF \\
\hline A & 24 & $1.60 \mathrm{E}+02( \pm 1.28 \mathrm{E}+01)$ & $185 \pm 14.8$ \\
\hline B & 24 & $1.23 \mathrm{E}+02( \pm 1.62 \mathrm{E}+01)$ & $240 \pm 31.4$ \\
\hline A & 120 & $8.86 \mathrm{E}+01( \pm 1.15 \mathrm{E}+01)$ & $333 \pm 43.3$ \\
\hline B & 120 & $1.03 \mathrm{E}+02( \pm 1.16 \mathrm{E}+01)$ & $286 \pm 32.0$ \\
\hline Blank & $\begin{array}{c}\text { Time } \\
(\mathbf{h})\end{array}$ & $\begin{array}{c}\text { Supernate } \\
\text { Sr }(\mathbf{d p m} / \mathbf{m L})\end{array}$ & DF \\
\hline 0 & 0 & $2.96 \mathrm{E}+04( \pm 5.91 \mathrm{E}+03)$ & $\mathrm{NA}$ \\
\hline 1 & 24 & $2.77 \mathrm{E}+04( \pm 5.59 \mathrm{E}+02)$ & $\mathrm{NA}$ \\
\hline 2 & 96 & $2.67 \mathrm{E}+04( \pm 5.42 \mathrm{E}+02)$ & $\mathrm{NA}$ \\
\hline 3 & 120 & $2.75 \mathrm{E}+04( \pm 5.56 \mathrm{E}+02)$ & $\mathrm{NA}$ \\
\hline Experiment & Strike \# & $\begin{array}{c}\mathbf{8 5} \mathbf{S u p e r n a t e} \\
\text { (dpm/mL })\end{array}$ & DF \\
\hline A & 1 & $1.43 \mathrm{E}+02( \pm 1.29 \mathrm{E}+01)$ & $207 \pm 18.7$ \\
\hline B & 1 & $1.13 \mathrm{E}+03( \pm 5.85 \mathrm{E}+01)$ & $26.1 \pm 1.35$ \\
\hline A & 2 & $5.24 \mathrm{E}+02( \pm 5.89 \mathrm{E}+01)$ & $56.4 \pm 6.35$ \\
\hline B & 2 & $5.40 \mathrm{E}+02( \pm 3.22 \mathrm{E}+01)$ & $54.7 \pm 3.27$ \\
\hline A & 3 & $1.33 \mathrm{E}+03( \pm 7.21 \mathrm{E}+01)$ & $22.2 \pm 1.20$ \\
\hline B & 3 & $9.97 \mathrm{E}+02( \pm 7.80 \mathrm{E}+01)$ & $29.7 \pm 2.33$ \\
\hline A & 4 & $2.14 \mathrm{E}+03( \pm 1.18 \mathrm{E}+02)$ & $13.8 \pm 0.756$ \\
\hline B & 4 & $2.05 \mathrm{E}+03( \pm 1.15 \mathrm{E}+02)$ & $14.4 \pm 0.811$ \\
\hline A & 5 & $3.58 \mathrm{E}+03( \pm 9.80 \mathrm{E}+01)$ & $8.26 \pm 0.226$ \\
\hline B & 5 & $3.44 \mathrm{E}+03( \pm 9.49 \mathrm{E}+01)$ & $8.59 \pm 0.237$ \\
\hline
\end{tabular}


Figure 14. ${ }^{85} \mathrm{Sr}$ in Solution

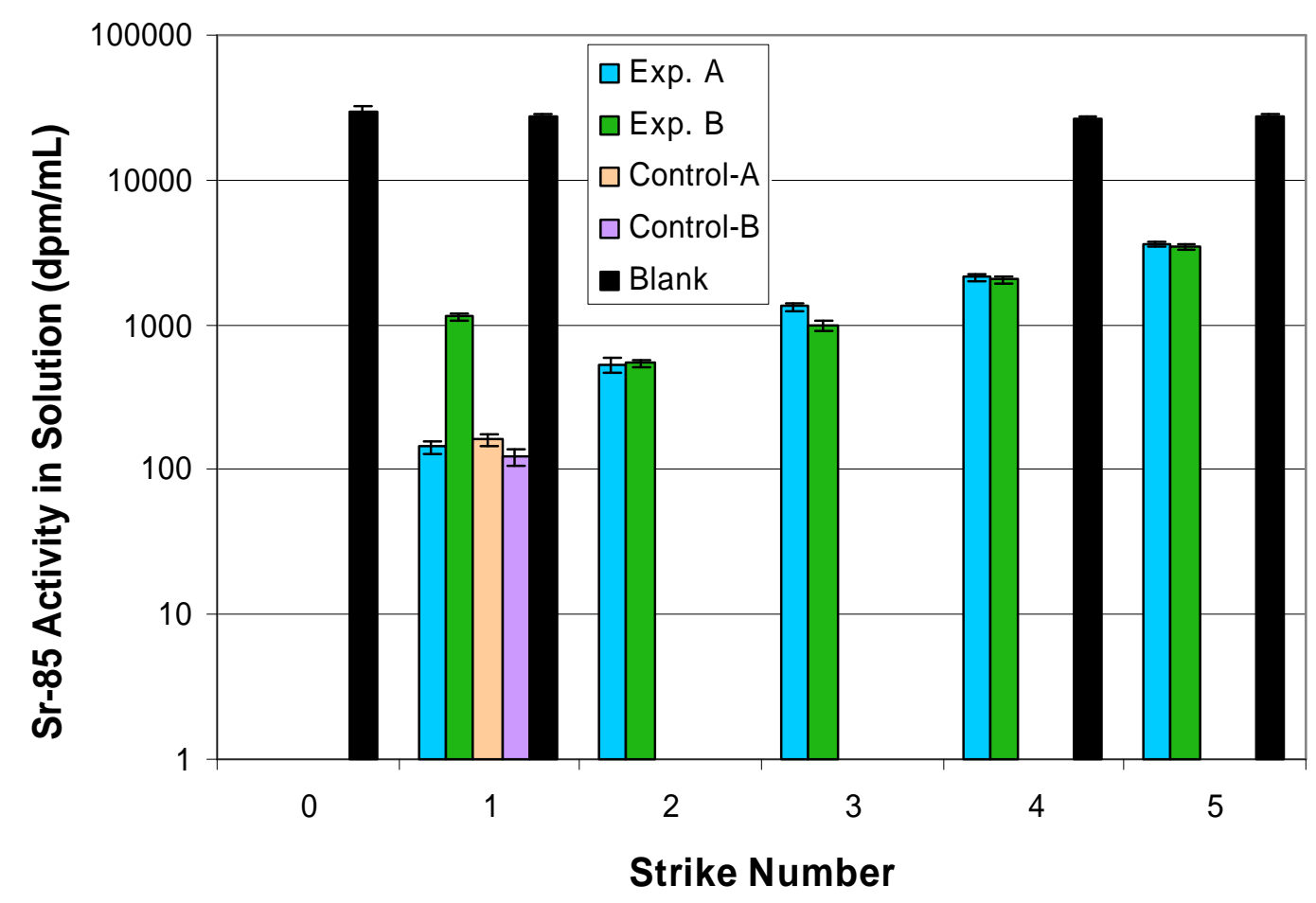

\subsubsection{Cumulative Loading of Strontium onto MST}

Given the low strontium mass concentration in the simulant, we did not determine the loading of strontium onto the MST solids. We did measure the ${ }^{85} \mathrm{Sr}$ content in the recovered solids so that we could determine the ${ }^{85} \mathrm{Sr}$ activity balance.

\subsubsection{Strontium Activity Balance}

One check of internal data consistency is to determine the sum of strontium sorbed based on the analytical results from the filtrate and compare with the amount of strontium measured on the digested MST solids. Table 40 contains the data. For the strontium in the supernate before MST addition, the value is the average of four samples (i.e., three from equilibration and one initial sample). For the strontium on the digested MST, the amount of strontium captured on all the MST is corrected for the recovered quantity of 
MST (85-94\% depending on which experiment). In Table 35, the \% Activity Balance term is calculated by dividing the sum of [strontium measured on the MST and the strontium left in each of the five bottles after the addition of MST] by the sum of [amount of strontium present in each of the five strike bottles before the addition of MST]. Across all replicates the activity balance averaged $87.2 \pm 4.36 \%$ for tracer strontium.

Table 40. ${ }^{85}$ Sr Activity Balance

\begin{tabular}{|c|c|c|c|c|}
\hline & $\begin{array}{c}{ }^{85} \text { Sr in Filtrate } \\
\text { Before MST } \\
\text { (dpm) }\end{array}$ & $\begin{array}{c}{ }^{85} \text { Sr in Filtrate } \\
\text { after MST } \\
\text { (dpm) }\end{array}$ & $\begin{array}{c}{ }^{85} \text { Sr on MST } \\
\text { Solids } \\
\text { (dpm) }\end{array}$ & $\begin{array}{c}\text { \% Activity } \\
\text { Balance } \\
(\%)\end{array}$ \\
\hline A & $1.48 \mathrm{E}+08$ & $7.72 \mathrm{E}+03$ & $1.16 \mathrm{E}+08$ & 83.6 \\
\hline B & $1.48 \mathrm{E}+08$ & $8.15 \mathrm{E}+03$ & $1.16 \mathrm{E}+08$ & 84.0 \\
\hline Control A & $2.96 \mathrm{E}+07$ & $8.86 \mathrm{E}+01$ & $2.54 \mathrm{E}+07$ & 88.4 \\
\hline Control B & $2.96 \mathrm{E}+07$ & $1.03 \mathrm{E}+02$ & $2.72 \mathrm{E}+07$ & 92.9 \\
\hline
\end{tabular}

\subsection{DISCUSSION OF RESULTS}

Under current operational scenarios, reducing radionuclide concentrations in some waste solutions to waste acceptance levels may require multiple treatments with MST. The SWPF design allows for as many as three treatments. The first MST addition occurs in the Alpha Strike Process. Waste is then treated by Caustic-Side Solvent Extraction which results in minor solvent entrainment. The second treatment with MST will occur in the Alpha Finishing Facility. If waste requires three treatments to meet decontamination targets for alpha emitters, the first two treatments will occur via an internal recycle of the waste within the Alpha Strike Process followed by processing through CSSX and the Alpha Finishing Facility.

\subsection{Effect of CSSX Solvent on MST Performance}

The presumed presence of CSSX solvent in the SWPF facility presents an unknown in terms of how it will affect the performance of MST. To test this, we added $500 \mathrm{ppmv}$ of full CSSX solvent to one set of tests. The $500 \mathrm{ppmv}$ value conservatively bounds the anticipated entrainment during operation. The results show no statistical difference in the MST performance as a function of the presence of the CSSX solvent, even though the MST was intimately contacted with the solvent before use.

\subsection{Ability to Reuse MST from Alpha Finishing Facility}

The MST used in the Alpha Finishing Facility will only contact waste relatively lean in alpha emitters. This demonstration examined the residual capacity of the MST from the 
Alpha Finishing Facility for removing alpha emitters in fresh waste of higher concentration. Test results show that MST still retains appreciable capacity.

\subsection{Fissile Loading of MST}

In the SWPF, there will be an opportunity for MST to contact multiple batches of fresh waste. The repeated contacting will increase the potential for high fissile loading. The maximum loading of fissile species - particularly uranium - is not known and remains a technical risk. ${ }^{2}$ A separate report examined the effect of a single, high liquid to MST contact ratio. ${ }^{11}$ This work describes the effect of multiple contacts at a lower liquid to MST contact ratio, although using the same simulant as in the previous work. We chose to measure the mass sorbed in contact with a simulated waste solution that contains very high concentrations of uranium, plutonium and neptunium. The project team personnel selected these concentrations to approximately represent the highest expected values for waste solutions that will be processed through the SWPF.

Under the conditions tested, fissile loadings from the recovered MST solids were measured to be $0.953 \pm 0.0575 \mathrm{wt} \%$ for plutonium, $12.3 \pm 0.760 \mathrm{wt} \%$ for uranium, and $0.417 \pm 0.00279 \mathrm{wt} \%$ for neptunium. Calculations indicate good mass balance agreement for all three actinides. The measured loadings for uranium and plutonium in this study are considerably higher than those previously reported in support of the InTank Precipitation Facility, and are more in line with results reported from a recent study. ${ }^{11}$ The higher loadings are consistent with that expected given the much higher phase ratio and higher fissile concentrations in the simulated waste solution.

The researchers calculated the theoretical maximum loading assuming ion exchange of the sorbates (as $\mathrm{Pu}^{4+}, \mathrm{NpO}_{2}{ }^{+}, \mathrm{UO}_{2}{ }^{2+}$ and $\mathrm{Sr}^{2+}$ ) for sodium from MST without multilayer coverage (or surface precipitation) of radionuclides ${ }^{12}$ from an analysis of the MST physical structure. (Note that with multiple layer coverage, there is no established means to estimating theoretical capacity. Also note that prior MST testing does suggest multilayer - or polymeric - coverage may be possible for uranium, plutonium, or neptunium. ${ }^{13}$ ) By comparing this to the sum of the loaded fissile species (plutonium, uranium, neptunium), we find the total sorbate loading is $28 \%$ of the theoretical capacity. Appendix IV lists the calculations used to determine loading. This indicates a high degree of loading for the MST and confirms the conditions of these tests were challenging.

The observed behavior in the sorption of the actinides with successive contacts of a single batch of MST and fresh volumes of simulated waste solution does not follow a classical sorption mechanism. We conclude that the results are not due experimental error given the results prove very similar in duplicate tests. Note that the simulant featured a low strontium concentration. Thus, competition from strontium for sites on the MST should be very low and would not influence sorption to provide the observed behavior. 
One potential cause for the observed behavior may be due to precipitation upon contact with MST and sorbate-loaded MST solids. Precipitation could occur if the simulant is supersaturated in the actinides. The amount of precipitation would be proportional to the degree of supersaturation. Ultimately, the system would equilibrate with the concentrations of the actinides at or below their respective solubility limit. A precipitation mechanism should remove approximately the same amount of actinide upon each contact since it is the solution concentrations before (while supersaturated) that primarily drives the system to precipitate solids and achieve a lower actinide concentration. Thus, this mechanism is consistent with the experimental results that found approximately the same amount of the actinides removed from solution with each contact.

The uranium and plutonium concentrations in the simulant measured $26.5 \mathrm{mg} / \mathrm{L}$ and $0.847 \mathrm{mg} / \mathrm{L}$, which are considerably higher than that customarily used in waste solution simulants (ca. $10 \mathrm{mg} / \mathrm{L}$ for uranium and $0.2 \mathrm{mg} / \mathrm{L}$ for plutonium). The predicted solubility concentrations of uranium and plutonium in a salt solution having the targeted chemical composition in Table 5 are $3.8 \mathrm{mg} / \mathrm{L}$ with a $95 \%$ prediction interval range from $0.54 \mathrm{mg} / \mathrm{L}$ to $21 \mathrm{mg} / \mathrm{L}$ for uranium and $0.11 \mathrm{mg} / \mathrm{L}$ with an interval of 0.0085 to $1.4 \mathrm{mg} / \mathrm{L}$ for plutonium. Previous simulants having approximately $10 \mathrm{mg} / \mathrm{L}$ uranium and $0.2 \mathrm{mg} / \mathrm{L}$ plutonium and the same chemical composition as that tested in this study have exhibited no evidence of uranium and plutonium precipitation when stored at ambient laboratory conditions (typically $20-30{ }^{\circ} \mathrm{C}$ ) for several months.

We offer a comparison to an earlier study. The high activity simulant used in earlier testing in support of salt processing technology development contained $24.6 \mathrm{mg} / \mathrm{L}$ uranium and $0.28 \mathrm{mg} / \mathrm{L}$ plutonium. ${ }^{10}$ The chemical composition of this simulant is similar to that in this study, but with the chemical concentrations increased by a factor of 1.34 to a higher total sodium concentration of $7.5 \mathrm{M}$. The predicted solubility of uranium in this simulant is $4.8 \mathrm{mg} / \mathrm{L}$ with a $95 \%$ prediction interval range from $0.75 \mathrm{mg} / \mathrm{L}$ to 31 $\mathrm{mg} / \mathrm{L} .{ }^{14}$ For plutonium the predicted solubility is $0.17 \mathrm{mg} / \mathrm{L}$ with a $95 \%$ prediction interval range from $0.013 \mathrm{mg} / \mathrm{L}$ to $2.2 \mathrm{mg} / \mathrm{L}$. During the earlier testing we observed no evidence of instability of the solution with respect to uranium and plutonium precipitation.

Given that the measured solution concentration of uranium in the simulant used in this study exceeds that of the predicted upper value of the $95 \%$ confidence interval, the simulant may be supersaturated in uranium and, therefore, unstable with respect to precipitation of uranium. This is not the case with plutonium since the measured plutonium concentration is well below the upper value of the $95 \%$ confidence interval. Supersaturated solutions can exhibit an apparent stability (i.e., metastability) in which the supersaturated species remains dissolved for long periods of time. Onset of precipitation can initiate by a sudden change in temperature or the introduction of solid with surface 
sites that initiates nucleation. Thus, the simulant in this study may be supersaturated in uranium (and possibly plutonium) and upon addition of the MST, precipitation of the uranium commences at the surface of a MST particle (i.e. the MST serves as a seed crystal). The uranium continues to precipitate from solution producing a solid phase such as sodium diuranate, $\mathrm{Na}_{2} \mathrm{U}_{2} \mathrm{O}_{7}$. If plutonium precipitates, it is most likely to precipitate as plutonium dioxide $\left(\mathrm{PuO}_{2}\right)$.

Note that this mechanism is not likely to operate for neptunium since the concentration of neptunium in the simulant is $0.48 \mathrm{mg} / \mathrm{L}$, which is well below the reported solubility of neptunium in alkaline solutions (i.e., $30-130 \mathrm{mg} / \mathrm{L})^{15,16,17}$. Neptunium may be removed from solution by coprecipitating with the uranium. Uranium is known to serve as a coprecipitating agent for plutonium and may well coprecipitate neptunium as well. ${ }^{18}$

To assess if the simulant is supersaturated in the actinides and, therefore, metastable with respect to precipitation we recommend that tests be carried to see if precipitation can be induced by nucleating agents other than MST (e.g., sodium diuranate, iron oxide or managanese oxide). Also, one could isolate solids after contacting the solution with MST and perform microscopic examination to determine if there are solids that contain only actinides (i.e., no titanium).

An alternate removal mechanism is sorption of colloidal particles. Colloids, if present, would be small enough to pass through the 0.1-micron membrane filters used in preparation of the simulant. The colloids could then sorb onto the MST resulting in a solid phase that can be removed by filtration. Note that the solids produced by this mechanism would be similar and difficult to distinguish between that produced upon precipitating multiple layers on the surface of the MST.

This mechanism seems less likely than a precipitation mechanism since one would expect more variation and generally less sorption in subsequent contacts as the available sites on MST are reduced. However, the colloidal actinide may be able to sorb onto a previously sorbed colloidal particle. To assess if this mechanism may be operable, the simulant could be tested for the presence of colloidal actinide particles by passing through a series of finer pore membranes. 


\subsection{CONCLUSIONS}

The current design of the Salt Waste Processing Facility (SWPF) includes an auxiliary facility, the Actinide Finishing Facility, which provides a second contact of monosodium titanate (MST) to remove soluble actinides and strontium from waste. This treatment will occur after cesium removal by Caustic-Side Solvent Extraction (CSSX). Provisions also exist to recover the MST from this operation and return to the initial actinide removal step in the SWPF for an additional (third) contact with fresh waste. A U.S. Department of Energy (DOE) request identified the need to study the following issues involving this application of MST.

- Determine the effect of organics from the solvent extraction (CSSX) process on radionuclide sorption by MST.

- Determine the efficiency of re-using MST for multiple contacts.

- Examine fissile loading on MST under conditions relevant to the SWPF operations using a waste containing significantly elevated concentrations of plutonium, uranium neptunium, and strontium.

This report describes the results of three experimental studies conducted to address these needs.

- Addition of high concentrations of 500 ppmv entrained CSSX solvent had no noticeable effect, over a two week period, on the sorption of the actinides and strontium by MST in a direct comparison experiment.

- Test results show that MST still retains appreciable capacity after being used once. For instance, reused MST - in the presence of entrained solvent continued to sorb actinides and strontium.

- A single batch of MST was used to sequentially contact five volumes of a simulant solution containing elevated concentrations of the radionuclides of interest. After the five sequential contacts, we measured the following solution actinide loadings on the MST:

plutonium: $0.884 \pm 0.00539 \mathrm{wt} \%$ or $(1.02 \pm 0.0112) \mathrm{E}+04 \mu \mathrm{g} / \mathrm{g}$ MST, uranium: $12.1 \pm 0.786 \mathrm{wt} \%$ or $(1.40 \pm 0.104) \mathrm{E}+05 \mu \mathrm{g} / \mathrm{g} \mathrm{MST}$, and neptunium: $0.426 \pm 0.00406$ wt $\%$ or $(4.92 \pm 0.0923) \mathrm{E}+03 \mu \mathrm{g} / \mathrm{g}$ MST.

- Over the duration of an experiment through the sequential strikes, the ability of MST to sorb actinides improved with additional uses. This trend is counterintuitive, but is confirmed by replicate experiments for plutonium, uranium, and neptunium. Conversely, over the duration of the experiment, the ability of MST to sorb strontium decreased the more it was used. This trend is also confirmed by replicate experiment. 


\section{APPENDIX I. Simulant Equilibrium Measurements}

\section{MST Reuse Simulant ( $1^{\text {st }}$ Attempt $)$}

\begin{tabular}{|c|c|c|}
\hline Component & Target Concentration & Measured Result \\
\hline nitrate & $2.60 \mathrm{M}$ & $2.71 \pm 0.271$ \\
\hline free hydroxide & $1.33 \mathrm{M}$ & $1.31 \pm 0.131$ \\
\hline sulfate & $0.521 \mathrm{M}$ & $0.526 \pm 0.0526$ \\
\hline nitrite & $0.134 \mathrm{M}$ & $0.142 \pm 0.0142$ \\
\hline (AA) total $\mathrm{Na}^{+}$ & $5.60 \mathrm{M}$ & $5.27 \pm 1.05$ \\
\hline (ICPES) total Na $^{+}$ & $5.60 \mathrm{M}$ & $4.91 \pm 0.491$ \\
\hline stable strontium & $11,000 \mu \mathrm{g} / \mathrm{L}$ & $7,360 \pm 1,470$ \\
\hline${ }^{85} \mathrm{Sr}$ & $50,000 \mathrm{dpm} / \mathrm{mL}$ & $47,300 \pm 771$ \\
\hline${ }^{237} \mathrm{~Np}$ & $500 \mu \mathrm{g} / \mathrm{L}$ & $86.8 \pm 17.4$ \\
\hline${ }^{238} \mathrm{U}$ & $25,000 \mu \mathrm{g} / \mathrm{L}$ & $9,170 \pm 1830$ \\
\hline${ }^{239 / 40} \mathrm{Pu}$ & $1200 \mu \mathrm{g} / \mathrm{L}$ & $19.5 \pm 0.975$ \\
\hline
\end{tabular}

MST Reuse Simulant ( $2^{\text {nd }}$ Attempt $)$

\begin{tabular}{|c|c|c|}
\hline Component & Target Concentration & Measured Result \\
\hline nitrate & $2.60 \mathrm{M}$ & $2.74 \pm 0.274$ \\
\hline free hydroxide & $1.33 \mathrm{M}$ & $1.19 \pm 0.119$ \\
\hline sulfate & $0.521 \mathrm{M}$ & $0.564 \pm 0.0564$ \\
\hline nitrite & $0.134 \mathrm{M}$ & $0.143 \pm 0.0143$ \\
\hline total Na & $5.60 \mathrm{M}$ & $5.20 \pm 0.520$ \\
\hline stable strontium & $11,000 \mu \mathrm{g} / \mathrm{L}$ & $9010 \pm 1800$ \\
\hline${ }^{85} \mathrm{Sr}$ & $50,000 \mathrm{dpm} / \mathrm{mL}$ & $30,700 \pm 699$ \\
\hline${ }^{237} \mathrm{~Np}$ & $500 \mu \mathrm{g} / \mathrm{L}$ & $165 \pm 33.0$ \\
\hline${ }^{238} \mathrm{U}$ & $25,000 \mu \mathrm{g} / \mathrm{L}$ & $15,700 \pm 3140$ \\
\hline${ }^{239 / 40} \mathrm{Pu}$ & $1200 \mu \mathrm{g} / \mathrm{L}$ & $190 \pm 10.8$ \\
\hline
\end{tabular}


WSRC-STI-2006-00012, REV. 0

MST Reuse Simulant $\left(3^{\text {rd }}\right.$ Attempt $)$

\begin{tabular}{|c|c|c|}
\hline Component & Target Concentration & Measured Result \\
\hline nitrate & $2.60 \mathrm{M}$ & $2.99 \pm 0.299$ \\
\hline free hydroxide & $1.33 \mathrm{M}$ & $1.22 \pm 0.122$ \\
\hline sulfate & $0.521 \mathrm{M}$ & $0.477 \pm 0.0477$ \\
\hline nitrite & $0.134 \mathrm{M}$ & $0.14 \pm 0.014$ \\
\hline total Na ${ }^{+}$ & $5.60 \mathrm{M}$ & $4.91 \pm 0.491$ \\
\hline stable strontium & $9,320 \mu \mathrm{g} / \mathrm{L}$ & $9,270 \pm 1,940$ \\
\hline${ }^{85} \mathrm{Sr}$ & $50,000 \mathrm{dpm} / \mathrm{mL}$ & $56,600 \pm 1,130$ \\
\hline${ }^{237} \mathrm{~Np}$ & $165 \mu \mathrm{g} / \mathrm{L}$ & $121 \pm 24.2$ \\
\hline${ }^{238} \mathrm{U}$ & $15,700 \mu \mathrm{g} / \mathrm{L}$ & $13,800 \pm 2,760$ \\
\hline${ }^{238} \mathrm{Pu}$ & $50,000 \mathrm{dpm} / \mathrm{mL}$ & $56,700 \pm 2,880$ \\
\hline
\end{tabular}

Table of Equilibrium Data

\begin{tabular}{|c|c|c|c|}
\hline \multirow{2}{*}{ Analyte } & \multicolumn{3}{|c|}{ Time } \\
\cline { 2 - 4 } & 24 hours & 168 hours & 336 hours \\
\hline${ }^{238} \mathrm{Pu}(\mathrm{dpm} / \mathrm{mL})$ & $(5.94 \pm 0.254) \mathrm{E}+04$ & $(4.96 \pm 0.240) \mathrm{E}+04$ & $(6.10 \pm 0.325) \mathrm{E}+04$ \\
\hline${ }^{239} \mathrm{Pu}(\mu \mathrm{g} / \mathrm{L})$ & $(7.84 \pm 1.57) \mathrm{E}+01$ & $(8.24 \pm 1.65) \mathrm{E}+01$ & $(8.70 \pm 1.74) \mathrm{E}+01$ \\
\hline${ }^{238} \mathrm{U}(\mu \mathrm{g} / \mathrm{L})$ & $(1.40 \pm 0.280) \mathrm{E}+04$ & $(1.35 \pm 0.270) \mathrm{E}+04$ & $(1.38 \pm 0.276) \mathrm{E}+04$ \\
\hline${ }^{237} \mathrm{~Np}(\mu \mathrm{g} / \mathrm{L})$ & $(1.28 \pm 0.256) \mathrm{E}+02$ & $(1.11 \pm 0.222) \mathrm{E}+02$ & $(1.24 \pm 0.248) \mathrm{E}+02$ \\
\hline${ }^{88} \mathrm{Sr}(\mu \mathrm{g} / \mathrm{L})$ & $(9.52 \pm 1.90) \mathrm{E}+03$ & $(8.96 \pm 1.79) \mathrm{E}+03$ & $(9.32 \pm 1.86) \mathrm{E}+03$ \\
\hline${ }^{85} \mathrm{Sr}(\mathrm{dpm} / \mathrm{mL})$ & $(5.53 \pm 0.0968) \mathrm{E}+04$ & $(5.92 \pm 0.140) \mathrm{E}+04$ & $(5.54 \pm 0.0970) \mathrm{E}+04$ \\
\hline
\end{tabular}

Based upon the analyses, SRNL declared the simulant ready for use. Due to equipment problems, personnel did not have ICPES data for sodium analysis at the end of the two week equilibration period. The customer concurred with proceeding without the ICPES result for sodium, based upon the knowledge that the previous (months earlier) measurement of this solution provided an adequate sodium result (i.e., 5.20 M). 
WSRC-STI-2006-00012, REV. 0

Fissile Loading Simulant

\begin{tabular}{|c|c|c|}
\hline Component & Target Concentration & Measured Result \\
\hline nitrate & $2.60 \mathrm{M}$ & $2.59 \pm 0.259$ \\
\hline free hydroxide & $1.33 \mathrm{M}$ & $1.34 \pm 0.134$ \\
\hline sulfate & $0.521 \mathrm{M}$ & $0.508 \pm 0.0508$ \\
\hline nitrite & $0.134 \mathrm{M}$ & $0.133 \pm 0.0133$ \\
\hline total Na & $5.60 \mathrm{M}$ & $5.13 \pm 0.513$ \\
\hline${ }^{85} \mathrm{Sr}$ & $50,000 \mathrm{dpm} / \mathrm{mL}$ & $29,500 \pm 590$ \\
\hline${ }^{237} \mathrm{~Np}$ & $500 \mu \mathrm{g} / \mathrm{L}$ & $476 \pm 95.2$ \\
\hline${ }^{238} \mathrm{U}$ & $25,000 \mu \mathrm{g} / \mathrm{L}$ & $26,500 \pm 5,300$ \\
\hline${ }^{239 / 40} \mathrm{Pu}$ & $1,200 \mu \mathrm{g} / \mathrm{L}$ & $847 \pm 169$ \\
\hline
\end{tabular}

Table of Equilibrium Data

\begin{tabular}{|c|c|c|c|}
\hline \multirow{2}{*}{ Analyte } & \multicolumn{3}{|c|}{ Time } \\
\cline { 2 - 4 } & 24 hours & 168 hours & 336 hours \\
\hline${ }^{239 / 40} \mathrm{Pu}(\mu \mathrm{g} / \mathrm{L})$ & $(8.78 \pm 0.421) \mathrm{E}+02$ & $(9.25 \pm 0.481) \mathrm{E}+02$ & $(8.13 \pm 0.398) \mathrm{E}+02$ \\
\hline${ }^{239} \mathrm{Pu}(\mu \mathrm{g} / \mathrm{L})$ & $(9.14 \pm 1.83) \mathrm{E}+02$ & $(8.50 \pm 1.70) \mathrm{E}+02$ & $(8.30 \pm 1.66) \mathrm{E}+02$ \\
\hline${ }^{238} \mathrm{U}(\mu \mathrm{g} / \mathrm{L})$ & $(2.78 \pm 0.556) \mathrm{E}+04$ & $(2.68 \pm 0.536) \mathrm{E}+04$ & $(2.64 \pm 0.528) \mathrm{E}+04$ \\
\hline${ }^{237} \mathrm{~Np}(\mu \mathrm{g} / \mathrm{L})$ & $(5.20 \pm 1.04) \mathrm{E}+02$ & $(4.86 \pm 0.972) \mathrm{E}+02$ & $(4.76 \pm 0.952) \mathrm{E}+02$ \\
\hline${ }^{85} \mathrm{Sr}(\mathrm{dpm} / \mathrm{mL})$ & $(3.30 \pm 0.0644) \mathrm{E}+04$ & $(2.98 \pm 0.0581) \mathrm{E}+04$ & $(2.95 \pm 0.0575) \mathrm{E}+04$ \\
\hline
\end{tabular}




\section{APPENDIX II. Uncertainty Calculations}

In each of the tests, the Decontamination Factor (DF) is calculated by dividing the initial species concentration by the species concentration at each of 6,24 , and 168 hours. The uncertainty value for a DF is derived from the individual uncertainties of the initial and final species concentrations. The DF uncertainty is determined as shown in equation 2.

Uncertainty $=\mathrm{DF} * \sqrt{(\% \text { initial uncertainty })^{2}+(\% \text { final uncertainty })^{2}} \quad$ Equation 2

Furthermore, when calculating the DF values for the six hour results, we have to take into account that the 6 hour final results use the average of three values. In this case, the $\%$ final uncertainty is determined as shown in equation 3.

$\%$ final uncertainty $=\frac{\left(\frac{\text { STDEV (final values) }}{\operatorname{SQRT}(3)}\right)}{\text { AVERAGE (final values) }} \quad$ Equation 3




\section{APPENDIX III. Protactinium Data Workup}

Even though the half-life of ${ }^{237} \mathrm{~Np}$ is lengthy $(2.14 \mathrm{E}+06 \mathrm{y})$, solutions containing ${ }^{237} \mathrm{~Np}$ generate measurable amounts of ${ }^{233} \mathrm{~Pa}$. Since the half-life of ${ }^{233} \mathrm{~Pa}$ is short $(27 \mathrm{~d})$, the high specific activity of ${ }^{233} \mathrm{~Pa}(2.08 \mathrm{E}+04 \mathrm{Ci} / \mathrm{g})$ means that even minute concentrations of ${ }^{233} \mathrm{~Pa}$ are detectable. More importantly, when attempting to understand the effects of MST on ${ }^{233} \mathrm{~Pa}$, compensation for this ingrowth is required. First, like any material with a short half-life (e.g. ${ }^{233} \mathrm{~Pa}$ and ${ }^{85} \mathrm{Sr}$ ), the data must be normalized to the first data point as follows.

corrected activity $=$ measured activity $/ \exp (-0.693 \times$ days to sample measurement/27)

Then, one needs to subtract the amount of ${ }^{233} \mathrm{~Pa}$ that has grown in during the interval. ingrowth activity $={ }^{237} \mathrm{~Np}$ activity $\times(1-\exp (-0.0257 \times$ elapsed time $))$

Finally, one calculates the adjusted, or corrected, activity by subtracting the ingrowth activity from the corrected activity.

For example, for the 24 hour ( 1 day) organic sample, we measured a ${ }^{237} \mathrm{~Np}$ activity of $528 \mathrm{dpm} / \mathrm{mL}$ and a ${ }^{233} \mathrm{~Pa}$ activity of $137 \mathrm{dpm} / \mathrm{mL}$ (already decay corrected).

The ingrowth activity $=528 \mathrm{dpm} / \mathrm{mL} \times(1-\exp (-0.0257 \times 1))=13.4 \mathrm{dpm} / \mathrm{mL}$

The adjusted activity $=137 \mathrm{dpm} / \mathrm{mL}-13.4 \mathrm{dpm} / \mathrm{mL}=124 \mathrm{dpm} / \mathrm{mL}$ 


\section{APPENDIX IV. Calculations for Theoretical Loading On MST}

The theoretical amount of actinide loading onto MST is determined by assuming the MST serves as ion exchanger capable of one exchanging one mole of sodium ions $\left(\mathrm{Na}^{+}\right)$ per mole of MST $\left(\mathrm{NaTi}_{2} \mathrm{O}_{5} \mathrm{H}\right)$. Thus, strontium and actinide ions replace sodium ions on the sodium titanate. We assume that the actinide species that sorb onto the MST are those added during the preparation of the simulant (i.e., $\mathrm{UO}_{2}{ }^{2+}, \mathrm{Pu}^{4+}$ and $\mathrm{NpO}_{2}{ }^{+}$). Therefore, it takes 2 sodium ions to exchange $\mathrm{UO}_{2}{ }^{2+}, 4$ sodium ions to exchange $\mathrm{Pu}^{4+}$, and 1 sodium to exchange $\mathrm{NpO}_{2}{ }^{+}$.

The known $\mu \mathrm{g}$ S/g MST value (where " $\mathrm{S}$ " is the sorbate in question: uranium, plutonium, or neptunium) is converted to moles S/g MST, then to cation equivalents. The actinide cation equivalents are then summed. This sum is divided by the cation equivalents per $\mathrm{g}$ of MST (=1/199.76) to give the $\%$ of theoretical loading.

\begin{tabular}{|c|c|c|c|c|}
\hline & $\mu \mathrm{g}$ S/g MST & mole S/g MST & $\begin{array}{c}\text { Total Cation } \\
\text { Equiv/g MST }\end{array}$ & \\
\hline $\mathrm{U}$ & $1.41 \mathrm{E}+05$ & $5.92 \mathrm{E}-04$ & $1.18 \mathrm{E}-03$ & $\mathrm{UO}_{2}^{2+}$ \\
\hline $\mathrm{Pu}$ & $1.06 \mathrm{E}+04$ & $4.44 \mathrm{E}-05$ & $1.77 \mathrm{E}-04$ & $\mathrm{Pu}^{4+}$ \\
\hline $\mathrm{Np}$ & $4.87 \mathrm{E}+03$ & $2.05 \mathrm{E}-05$ & $2.05 \mathrm{E}-05$ & $\mathrm{NpO}_{2}{ }^{+}$ \\
\hline & & & & $\begin{array}{c}\% \text { of Theoretical } \\
\text { Capacity }\end{array}$ \\
\hline & & Sum of U, Pu, Np & $1.38 \mathrm{E}-03$ & $\mathbf{2 7 . 6 2 \%}$ \\
\hline & & $\begin{array}{c}\text { Theoretical Capacity of } \\
\text { MST }\end{array}$ & $5.01 \mathrm{E}-03$ & \\
\hline
\end{tabular}




\subsection{REFERENCES}

${ }^{1}$ Salt Waste Processing Facility Project Basis of Design, P-DB-J-00001, Rev. 3, September 13, 2004, Parsons, Aiken, SC.

2 D. T. Hobbs, "Uranium Loading onto MST," SRT-LWP-2002-00105, October 1, 2002.

${ }^{3}$ SPP Scope of Work: Supplemental MST Studies, December 9, 2004.

${ }^{4}$ F. F. Fondeur, D. T. Hobbs, S. D. Fink, and M. J. Barnes, "Sorption Modeling of Sr, Pu, U and Np Adsorption on MST", WSRC-TR-2003-00180, April 2003.

${ }^{5}$ Michael R. Poirier, Jeff L. Siler, and Samuel D. Fink, "Filtration of Actual Savannah River WasteTreated With Permanganate or Monosodium Titanate”, WSRC-TR-200200134, Rev. 0, March 14, 2002.

${ }^{6}$ D. T. Hobbs, M. G. Bronikowski, T. B. Edwards and R. L. Pulmano, "Final Report on Phase III Testing of Monosodium Titanate Adsorption Kinetics," WSRC-TR-99-00134, Rev. 0, May 28, 1999.

${ }^{7}$ M. J. Barnes, T. B. Edwards, D. T. Hobbs, and K. N. Marshall, "Strontium and Actinide Removal testing with Monosodium Titanate and Other Sorbents", WSRC-TR-200100436, Rev. 0, October 29, 2001.

${ }^{8}$ M. J. Barnes, F. F. Fondeur, D. T. Hobbs, and S. D. Fink, "Monosodium Titanate MultiStrike Testing," WSRC-TR-2004-00145, Rev. 0, April 29, 2004

${ }^{9}$ Accountability Manual, “Accountability Standard Decay and Activity Values”, DPSOP 23-11.

${ }^{10}$ D. T. Hobbs, M. G. Bronikowski, T. B. Edwards, and R. L. Pulmano, "Final Report on Phase III Testing of Monosodium Titanate Adsorption Kinetics," WSRC-TR-99-00134, Rev. 0, May 28, 1999.

${ }^{11}$ T. B. Peters, D. T. Hobbs, and S. D. Fink, "Determination of Fissile Loadings onto Monosodium Titanate (MST) under Conditions Relevant to the Actinide Removal Process Facility", WSRC-TR-2005-00514, Rev. 0, November 15, 2005.

${ }^{12}$ D. T. Hobbs, "Theoretical Cation Exchange Capacity of MST", WSRC-NB-200500048, page 83, August 8, 2005.

${ }^{13}$ M. C. Duff, D. B. Hunter, D. T. Hobbs, M. J. Barnes, and S. D. Fink, "Characterization of Sorbed Uranium, Plutonium, and Neptunium on Monosodium Titanate," WSRC-TR2001-00356, September 19, 2001. 
${ }^{14}$ T. B. Edwards, "Confidence and Prediction Intervals for Recent Pu and U Solubility Models", SRT-SCS-2004-00043, Nov.22, 2004.

${ }^{15}$ J. H. Gray, "Neptunium Solubility Studies (U)," SRTC-CTS-94-0133, November 30, 1994.

${ }^{16}$ D. G. Karraker, "Solubility of Neptunium in Alkaline High Level Waste," WSRC-TR94-0526, Rev. 1, November 11, 1994.

${ }^{17}$ V. F. Peretrukhin, S. V. Kryutchkov, V. I. Silin, and I. G.Tananaev, "Determination of the Solubility of Np(IV)-(VI), Pu(III)-(VI), Am(III)-(VI) and Tc(IV), (V) Hydroxo Compounds in 0.4 - 14 M NaOH Solutions," WHC-EP-0987, September 1966.

${ }^{18}$ D. T. Hobbs, "Precipitation of Uranium and Plutonium from Alkaline Salt Solutions," Nuclear Technology, 1999 (128) 103 - 112. 